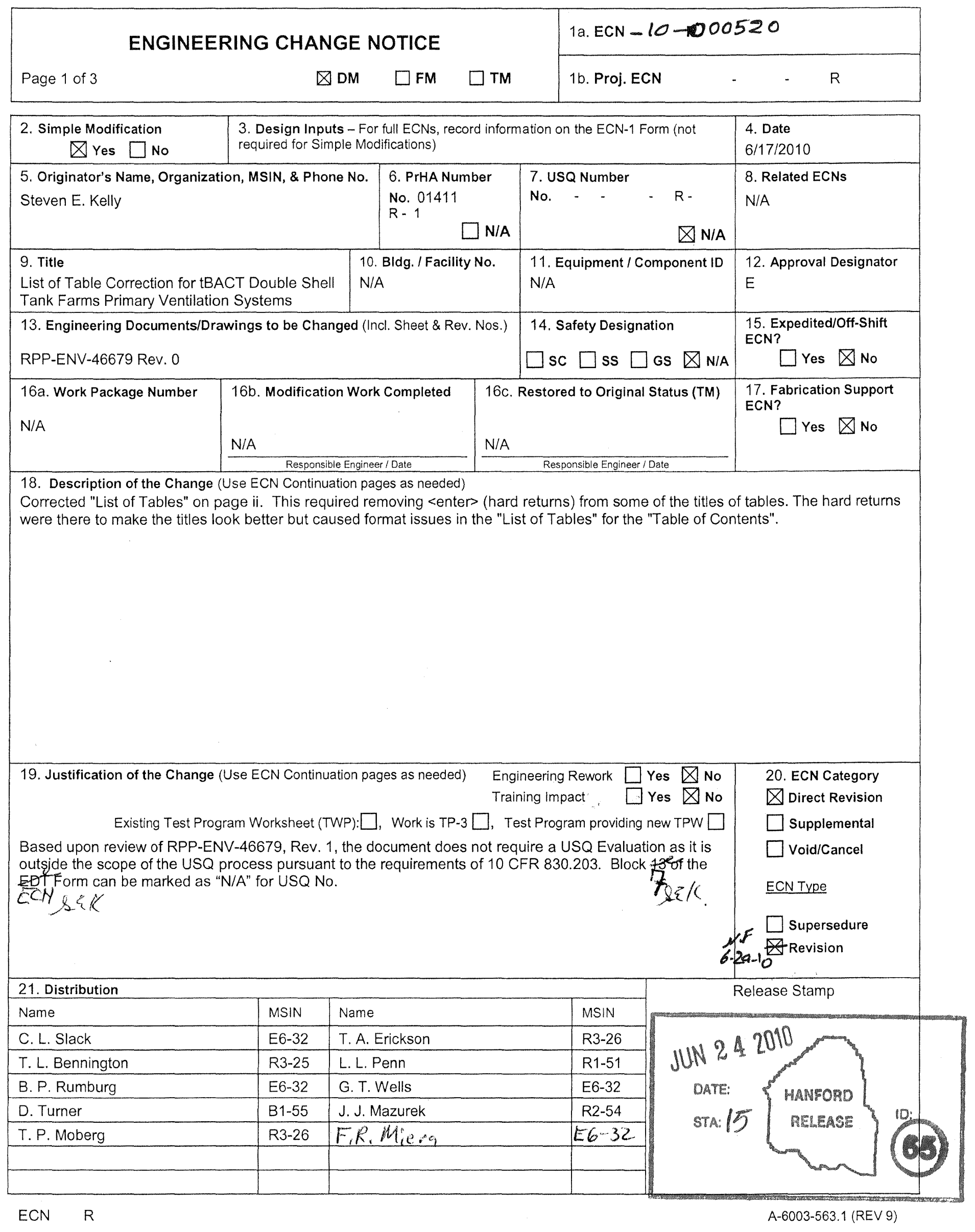




\section{ENGINEERING CHANGE NOTICE}

Page 2 of 3 $\triangle D M \quad \square F M$ 1a. ECN
$R$

\section{Revisions Planned (Include a brief description of the contents of each revision)}

N/A

Note: All revisions shall have the approvals of the affected organizations as identified in block 12 "Approval Designator," on page 1 of this ECN.

23. Commercial Grade Item Dedication Numbers (associated with this design change)

N/A
24. Engineering Data Transmittal Numbers (associated with this design change, e.g., new drawings, new documents)

823603

\section{Other Non Engineering (not in HDCS) documents that need to be modified due to this change}

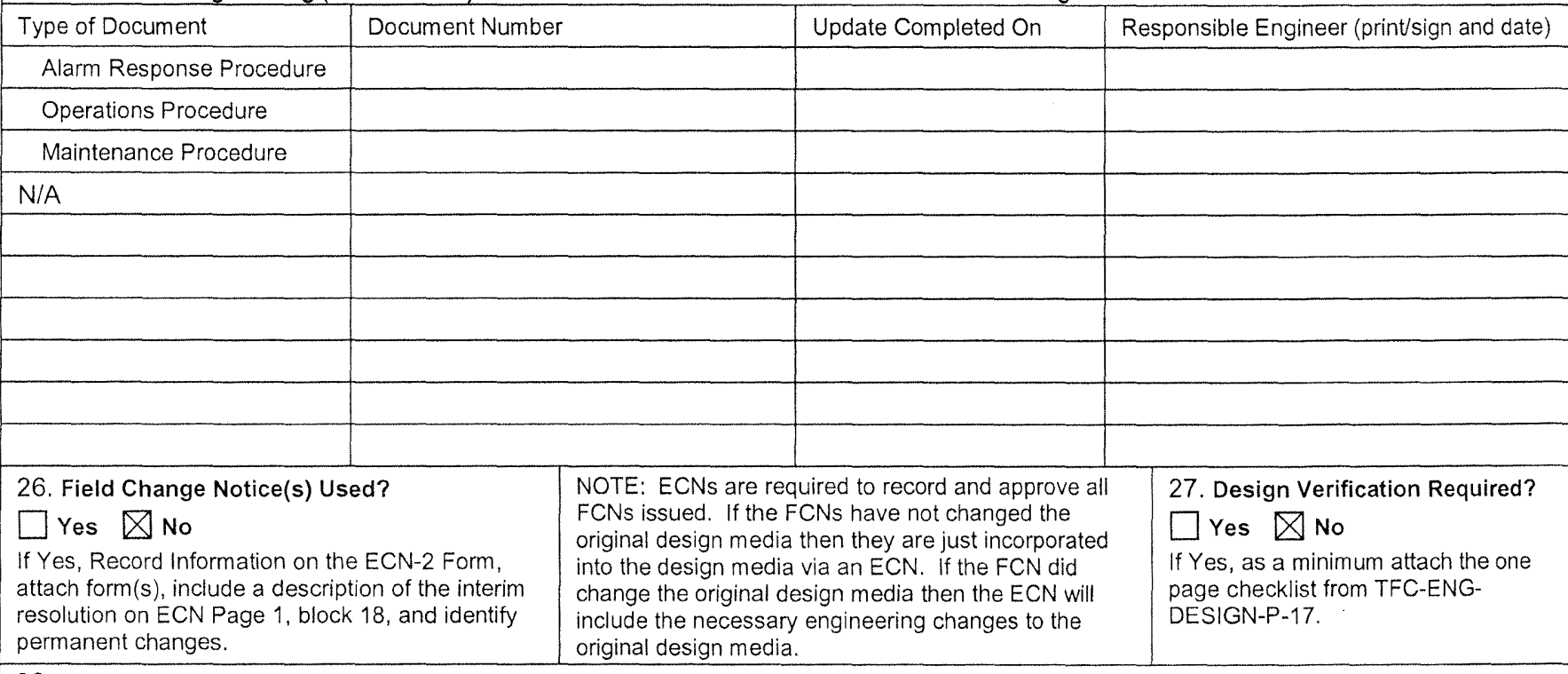

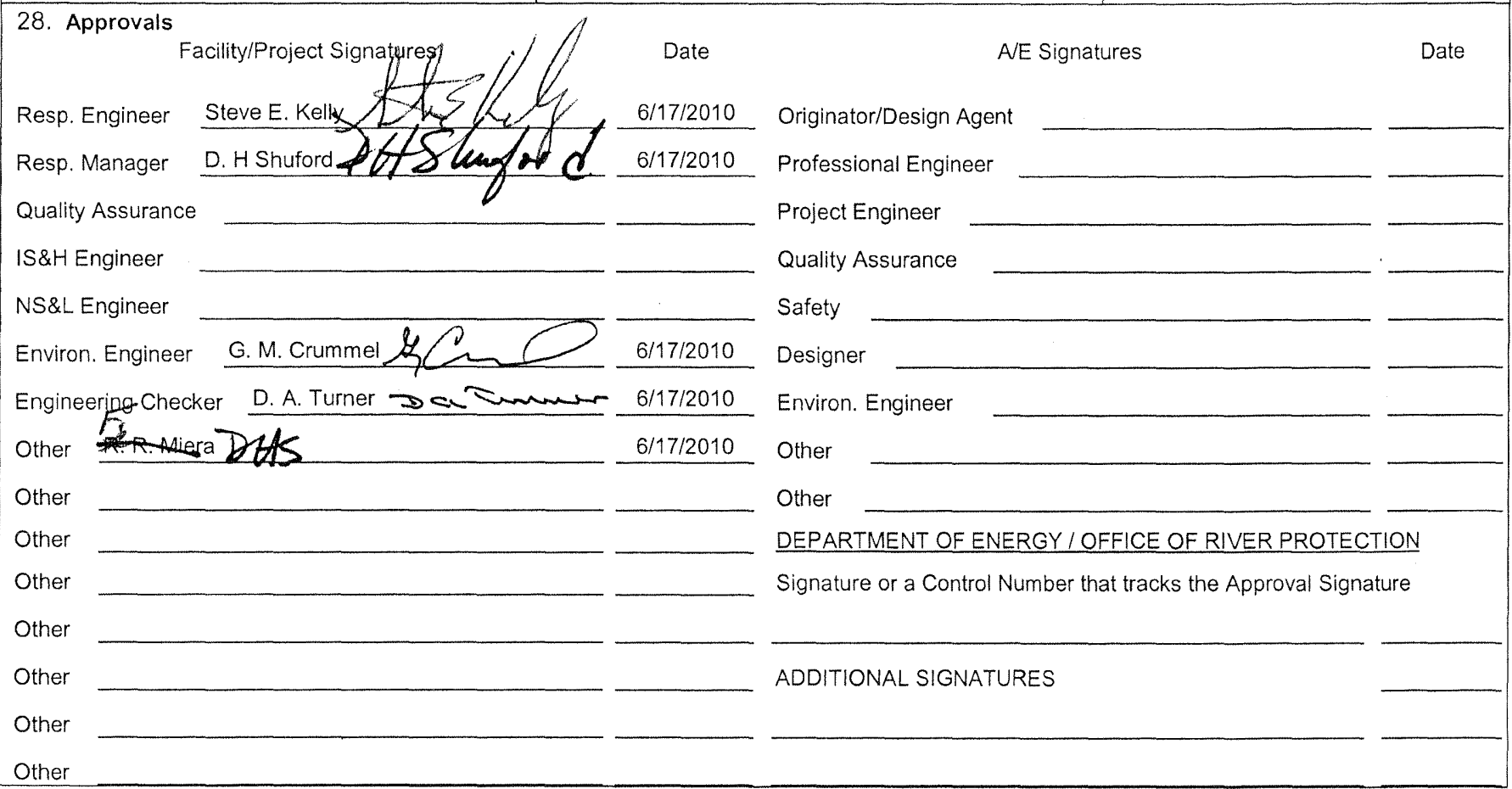




\title{
Evaluation of Best Available ControlTechnology for Toxics (tBACT) \\ Double Shell Tank Farms Primary Ventilation Systems Supporting Waste Transfer Operations
}

\author{
Carolyn C. Haass, J. Louis Kovach / Steven E. Kelly, David A. Turner \\ Columbia Nuclear International LLC / Washington River Protection Solutions \\ Richland, WA 99352 \\ U.S. Department of Energy Contract DE-AC27-08RV14800

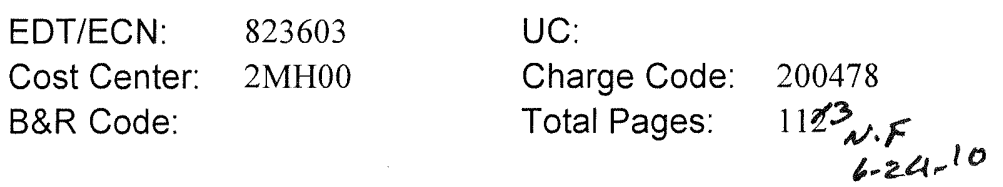

Key Words: tBACT, BACT, Ecology, Primary Ventilation Systems, 241-AN, 241-AP, 241-AW, 241AY, 241-AZ, 241-SY, ASIL

Abstract: This report is an evaluation of Best Available Control Technology for Toxics (tBACT) for installation and operation of the Hanford double shell (DST) tank primary ventilation systems. The DST primary ventilation systems are being modified to support Hanford's waste retrieval, mixing, and delivery of single shell tank (SST) and DST waste through the DST storage system to the Waste Treatment and Immobilization Plang (WTP).

TRADEMARK DISCLAIMER. Reference herein to any specific commercial product, process, or service by trade name, trademark, manufacturer, or otherwise, does not necessarily constitute or imply its endorsement, recommendation, or favoring by the United States Government or any agency thereof or its contractors or subcontractors.

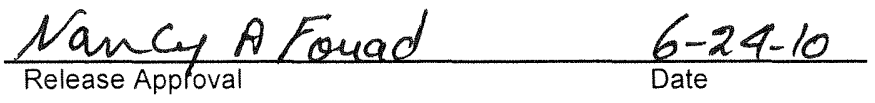

Approved For Public Release

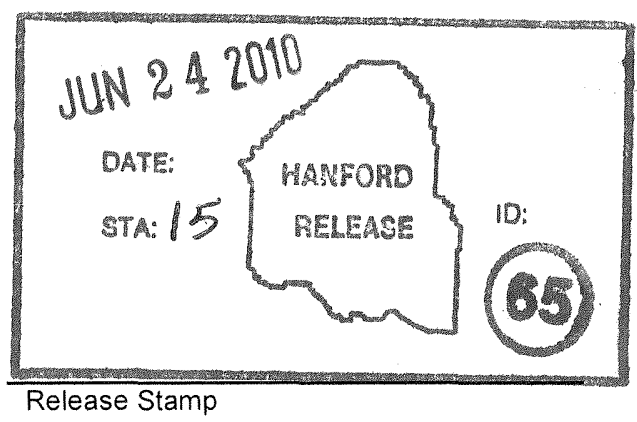




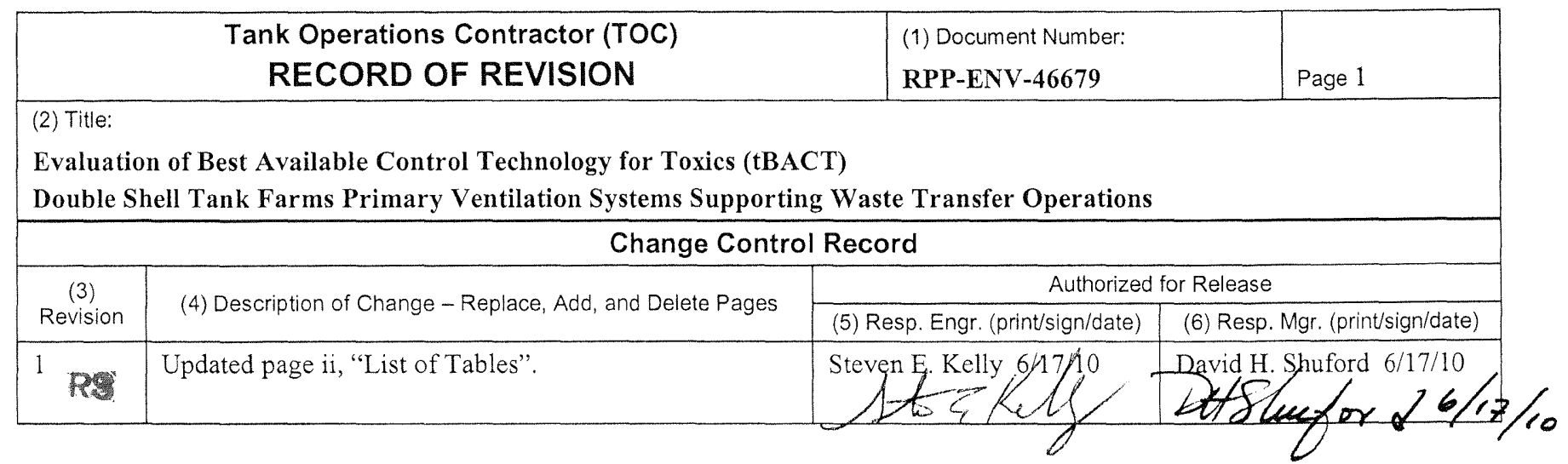




\section{EXECUTIVE SUMIMARY}

This report is an evaluation of Best Available Control Technology for Toxics (tBACT) for installation and operation of the Hanford double shell tank (DST) primary ventilation systems. The DST primary ventilation systems are being modified to support Hanford's waste retrieval, mixing, and delivery of single shell tank (SST) and DST waste through the DST storage system to the Waste Treatment and Immobilization Plant (WTP). The retrieval, pumping, and mixing of waste are expected to increase emissions of toxic air pollutants (TAPs) as defined in Washington Administrative Code (WAC) 173-460-150, Controls for New Sources of Toxic Air Pollutants. WAC 173-460-150 provides acceptable source impact levels (ASILs), small quantity emission rates (SQERs), and de minimis values for each TAP. WAC 173-460-060(2), Emission Standards for New and Modified Emission Units, requires that tBACT be employed for all TAPs for which the increase in emissions exceed the de minimis values.

The process used in this $\mathrm{BACT}$ evaluation was similar to that prior process used, documented, and approved by Ecology in the following tBACT evaluations.

- Letter July 31, 2007, J.A. Hedges to S Olinger, Approval of Criteria and Toxic Emissions Notice of Construction (NOC) Application, Hanford Single-Shell Tank Waste Retrieval, Approval Order DE05NWP-002 Rev. 2.

- Letter October 12, 2005, M.A. Wilson to R.J. Schepens, Approval of Criteria and Toxic Emissions Notice of Construction (NOC) Application for Operations of Waste Retrieval Systems in Single-Shell Tank (SST) Farms as Supplemented with C Farm Exhauster Operation Incorporating C-200 Series Tanks and Aggregated Exhaust Points for the 241-C Tank Farm, Approval Order DE05NWP-002, Rev. 1.

- Letter February 18, 2005, M.A. Wilson to R.J. Schepens, Approval of Non-Radioactive Air emissions Notice of Construction (NOC) for Operation of New Ventilation Systems in AN and AW Tank Farms, Approval Order DE05NWP-001.

The development of this $\mathrm{tBACT}$ followed guidance provided from Washington State Department of Ecology (Ecology) and the U.S. Environmental Protection Agency (EPA) for the process to determine best available control technologies (BACT). This tBACT follows the five-step BACT process, the steps are the following.

- Step 1 - Identify all available control technologies for each pollutant subject to review.

- Step 2 - Eliminate all technically infeasible control technologies.

- Step 3 - Rank the remaining control technologies by control effectiveness.

- Step 4 - Evaluate the feasible control technologies, beginning with the most efficient, with respect to economic, energy, and environmental impacts.

- Step 5 - Select as tBACT the most effective control technology that is not rejected based on adverse economic, environmental, and/or energy impacts.

This tBACT evaluation addresses 41 TAPs that exceed the de minimis values. TAPs with similar chemical and physical properties were placed into groups with the assumption that similar control technologies would be effective in abatement. The four separate groups that exceeded de minimis values were as follows:

- Ammonia

- Toxic organic compounds

- Mercury and mercury related compounds

- Particulate metal compounds. 
After a detailed evaluation of the four TAPs and/or groups and the effectiveness and costs of emission control technologies for each, a \$/ton cost was determined to implement a control technology as identified in Table ES-1. Most of the identified technologies were eliminated, because their \$/ton costs exceeded the cost ceiling guidelines previously approved by Ecology and EPA as economically unjustifiable. Although the evaluated technology would remove 98$99 \%$ of the pollutants, the cost of the abatement becomes prohibitive on a per ton basis due to the low emission rates.

Based on the results of this $\mathrm{ABACT}$ evaluation, the proposed $\mathrm{tBACT}$ control technology for the DST primary ventilation systems consists of a moisture de-entrainer, pre-heater, pre-filters, and a High Efficiency Particulate Air (HEPA) filtration system in the treatment train.

This tBACT evaluation is one part of the Notice of Construction (NOC) application that will be submitted to Ecology. It provides information on TAP emissions, control technologies proposed, why they were proposed, or why a technology was not feasible for mitigation of toxic emissions during DST waste operations.

\begin{tabular}{|c|c|c|c|c|}
\hline & $\begin{array}{l}\text { Total } \\
\text { Annualized } \\
\text { Costs (\$/year) }\end{array}$ & $\begin{array}{l}\text { Emissions per } \\
\text { Year (tons) }\end{array}$ & $\begin{array}{l}\text { Annual Cost of } \\
\text { Removal } \\
(\$ / \text { ton })^{\mathrm{a}}\end{array}$ & $\begin{array}{l}\text { Ceiling Cost } \\
\text { Effectiveness } \\
\text { Threshold (\$/ton) }\end{array}$ \\
\hline \multicolumn{5}{|l|}{ Toxic Organic Compounds } \\
\hline Thermal Non-Catalytic Oxidizer & $\$ 2,925,000$ & 0.481 & $\$ 6,081,000$ & $\$ 105,000$ \\
\hline Activated Carbon Adsorption & $\$ 790,000$ & 0.481 & $\$ 1,643,000$ & $\$ 105,000$ \\
\hline \multicolumn{5}{|l|}{ Ammonia } \\
\hline Thermal Non-Catalytic Oxidizer & $\$ 2,925,000$ & 13.12 & $\$ 223,000$ & $\$ 105,000$ \\
\hline Activated Carbon Adsorption & $\$ 5,148,000$ & 13.12 & $\$ 392,000$ & $\$ 105,000$ \\
\hline Scrubber & $\$ 7,583,000$ & 13.12 & $\$ 577,000$ & $\$ 105,000$ \\
\hline \multicolumn{5}{|l|}{$\begin{array}{l}\text { Mercury and Mercury Related } \\
\text { Compounds }\end{array}$} \\
\hline $\begin{array}{l}\text { Activated Treated Carbon } \\
\text { Adsorption }\end{array}$ & $\$ 92,000$ & 2.61E-04 & $\$ 352,000,000$ & $\$ 105,000$ \\
\hline Particulate Metal Compounds & \multicolumn{4}{|c|}{$\begin{array}{l}\text { Particulate metal compounds are removed by the required particulate filtration train } \\
\text { for removal of radionuclides at a } 99.95 \% \text { removal rate. }\end{array}$} \\
\hline
\end{tabular}


TABLE OF CONTENTS

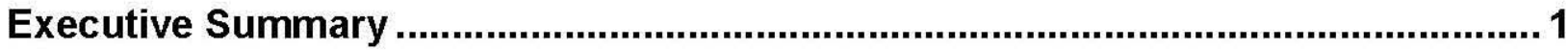

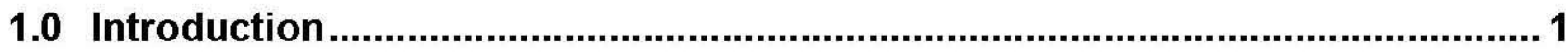

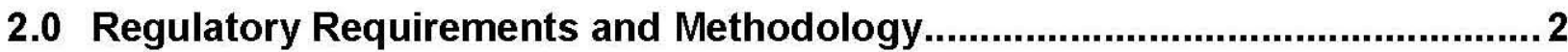

3.0 Double Shell Tank System Primary Ventilation System Description and

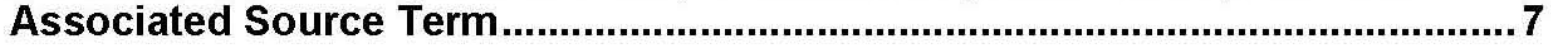

4.0 Identification and Evaluation of Emission Control Technology Options for Toxic Organic Compounds ......................................................................... 11

5.0 Identification and Evaluation of Emission Control Technology Options for

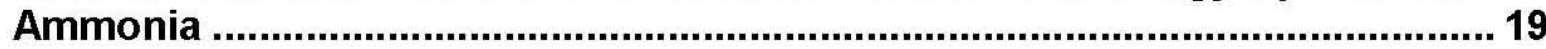

6.0 Identification and Evaluation of Emission Control Technology Options for

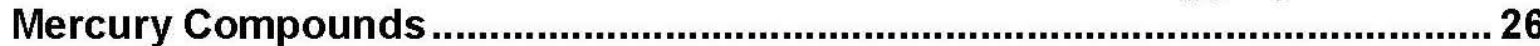

7.0 Identification and Evaluation of Emission Control Technology Options for Particulate Metal Compounds ......................................................................... 31

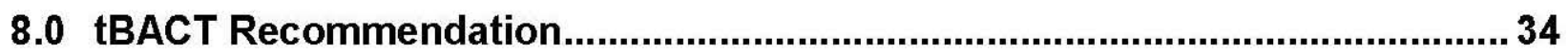

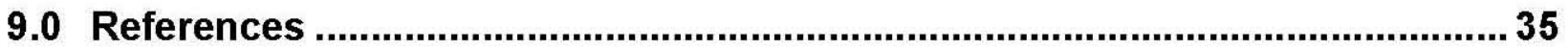

Table of Appendices

Appendix 1-A Thermal Oxidizer Cost Estimates ......................................................................

Appendix 1-B Thermal Non-Catalytic Cost Estimates......................................................50

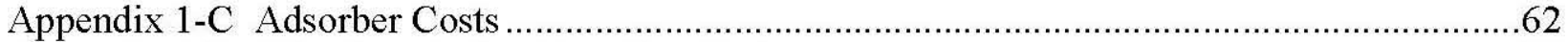

Appendix 1-D Wet Caustic Scrubber Cost Estimate..............................................................

Appendix 2_MERSOB® Mercury Adsorbents NUCON Bulletin 11B28, August 2004 …..........82

List of Figures

Figure 3-1. Location of Tank Farms in 200 East and 200 West Areas of the Hanford Site............7

Figure 3-2. Typical Current Double Shell Tank Primary Ventilation System .............................. 8

Figure 4-1. Typical Adsorption Isotherm (Benzene) ……..................................................

Figure 7-1. Filter Penetration Versus Particle Size................................................................. 


\section{List of Tables}

Table ES-1. Total Annualized Costs of Abatement Technologies, Emissions per Year, and the Cost of Removal per Ton Compared to the Ceiling Cost

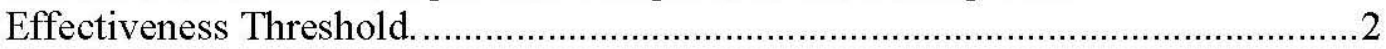

Table 2-1. tBACT Cost Factors

Table 2-2. ASIL Based Cost Factor Calculations for Compounds Above De Minimis

Thresholds

Table 3-1. TAPs With Emissions Above De Minimis Rates.....................................................10

Table 4-1. Toxic Organic Compounds - Potential tBACT.......................................................11

Table 4-2. tBACT Ranking by Effectiveness for Control of Toxic Organic Compounds ...........12

Table 4-3. Estimated Carbon Filter Breakthrough Times for Substances of Potential Concern in Stack Gases from Chemical Agent Disposal Facility Liquid Incinerator

Table 4-4. Toxic Organic Compounds -- Thermal Non-Catalytic Oxidation Capital and Annual Cost Summary

Table 4-5. Toxic Organic Compounds -- Activated Carbon Adsorption Capital and Annual Cost Summary.

Table 5-1. Ammonia - Potential tBACT

Table 5-2. tBACT Ranking by Effectiveness for Control of Ammonia

Table 5-3. Ammonia -- Thermal Non-Catalytic Oxidation Capital and Annual Cost Summary

Table 5-4. Ammonia -- Activated Carbon Adsorbers with Treated Adsorbent Capital and Annual Cost Summary .24

Table 5-5. Ammonia -- Wet Scrubber Adsorption Capital and Annual Cost Summary .............25

Table 6-1. Mercury Compounds - Potential tBACT.

Table 6-2. Mercury and Mercury Related Compounds - Fixed Carbon Beds with Chemically Treated Adsorbent tBACT Control Technology - Capital and Annual Cost Summary

Table 7-1. Particulate Concentrations

Table 8-1. Total Annualized Costs of Abatement Technologies, Emissions per Year, and the Cost of Removal per Ton Compared to the Ceiling Cost Effectiveness Threshold. 


\section{Terms, Acronyms, and Abbreviations}

ANSI

ASME

ASIL

BACT

BARCT

CAA

CAS\#

CFM

CFR

DF

DOE

DOE-ORP

DST

Ecology

ETF

EPA

ERDF

$\mathrm{Ft}$

HEPA

IAC

LAER

Lbs

LEL

MTZ

NOC

NOx

NRC

NSR

$\mathrm{RCW}$

RSD

SQER

SST

TAPs

tBACT

TOC

TWINS

VOC

WAC

WRPS

WTP

$\mathrm{Yr}$

$\$$

$\$ / y r$

$\mathrm{mg} / \mathrm{m}^{3}$

$\mu \mathrm{g} / \mathrm{m}^{3}$

$\mathrm{g} / \mathrm{sec}$
American National Standards Institute

American Society of Mechanical Engineers

Acceptable Source Impact Level

Best Available Control Technology

Best Available Radionuclide Control Technology

Clean Air Act

Chemical Abstract Service Registration Number

Cubic Feet Per Minute

Code of Federal Regulations

Decontamination Factor

Department of Energy

Department of Energy, Office of River Protection

Double Shell Tank

Washington State Department of Ecology

Effluent Treatment Facility

Environmental Protection Agency

Environmental Restoration Disposal Facility

Foot

High-Efficiency Particulate Air (Filter)

Impregnated Activated Carbon

Lowest Achievable Emission Rate

Pounds

Lower Explosive Limit

Mass Transfer Zone

Notice of Construction

Compounds of Nitrogen and Oxygen

National Research Council

New Source Review

Revised Code of Washington

Relative Standard Deviation

Small Quantity Emission Rate

Single Shell Tank

Toxic Air Pollutants

Best Available Control Technology for Toxics

Total Organic Carbon

Tank Waste Information Network System

Volatile Organic Compounds

Washington Administrative Code

Washington River Protection Solutions, LLC

Waste Treatment and Immobilization Plant

Year

U.S. Dollars

U.S. dollars per year

milligrams per cubic meter

micrograms per cubic meter

gram per second 


\subsection{INTRODUCTION}

The waste feed delivery mission requires all single shell tank (SST) wastes be transferred to the double shell tank (DST) system for future delivery to the Waste Treatment and Immobilization Plant (WTP). In preparation for this mission, new primary ventilation systems are being planned and designed for each DST farm. The first such primary ventilation system will replace the current primary ventilation system installed in the SY-241 Tank Farm.

Currently, DST farms are exhausted through a primary ventilation system that serves as a containment system for radioactive particulates present in the tank headspace, vents flammable gases and vapors that evolve from the liquid surface in the DSTs, and removes heat. The ventilation system operates by drawing outside air into and through the tank headspace. After the air leaves the headspace, the ventilation system conditions the outlet stream to remove entrained moisture, reduce relative humidity, and filter particulates. During exhaust it is discharged to atmosphere through the stack, the exhaust is monitored and sampled for radioactive particulates.

The new DST farm primary ventilation systems will replace the existing two parallel exhaust trains with two new parallel exhaust trains, each capable of providing up to nominally 2,000 $\mathrm{ft}^{3} / \mathrm{min}$ (standard) and maximum $3,000 \mathrm{ft}^{3} / \mathrm{min}$ (standard) exhaust flow. Primary ventilation systems are operated during all storage, treatment, retrieval, and transfer operations of the waste contained in the DSTs.

The new replacement primary ventilation systems are considered modifications to the DST system and require a new air source review in accordance with WAC 173-460-040, Controls of New Sources of Air Toxic Pollutants and WAC 173-400-110, New Source Review (NSR). In addition, a Notice of Construction (NOC) permit application is required if there are new pollutants emissions or if increases exceed the de minimis values listed in WAC 173-460-150, Controls for New Sources of Toxic Air Pollutant. In addition, an NOC application for all new or modified toxic air pollutant sources must demonstrate that the new or modified emission units employ tBACT for all toxic air pollutants (TAPs) where the increase in emissions exceed the de minimis emission values found in WAC 173-460-150.

RPP-RPT-44009 Rev 1, Spreadsheet Description Document for Non-Radiological Air Source Term for 241-SY Farm and 241-AP Farm Primary Ventilation Systems Upgrades (May 2010) and SVF-1821, Rev 1, Non-Rad Air Source Term for 241-SY Farm and 241-AP Farm Primary Ventilation System Upgrades.xlsx (May 2010) assessed unabated emissions to the DST farm primary ventilation systems. Several pollutants exceeded the WAC 173-460-150 de minimis values and one pollutant (dimethyl mercury) exceeded the Acceptable Source Impact Level (ASIL).

This tBACT evaluation is one part of the NOC application. It provides information on toxic air pollutant (TAP) emissions, control technologies proposed, why they were proposed, or why a technology was not feasible for mitigation of toxic emissions during DST waste operations. 


\subsection{Regulatory Requirements And Methodology}

WAC 173-460-020 defines "Best available control technology for toxics (tBACT)" as that term is defined in WAC 173-400-030, as applied to toxic air pollutants. Toxic air pollutants are defined as any toxic air pollutant listed in WAC 173-460-150.

WAC-173-400-030, defines "Best available control technology (BACT)" as:

"An emission limitation based on the maximum degree of reduction for each air pollutant subject to regulation under chapter $70.94 \mathrm{RCW}$ emitted from or which results from any new or modified stationary source, which the permitting authority, on a case-by-case basis, taking into account energy, environmental, and economic impacts and other costs, determines is achievable for such source or modification through application of production processes and available methods, systems, and techniques, including fuel cleaning, clean fuels, or treatment or innovative fuel combustion techniques for control of each such pollutant. In no event shall application of "best available control technology" result in emissions of any pollutants which will exceed the emissions allowed by any applicable standard under 40 CFR Part 60 and Part 61. Emissions from any source utilizing clean fuels, or any other means, to comply with this paragraph shall not be allowed to increase above levels that would have been required under the definition of BACT in the Federal Clean Air Act as it existed prior to enactment of the Clean Air Act Amendments of 1990."

This tBACT demonstration is a modification of EPA's BACT analysis procedure delineated in the New Source Review Workshop Manual, Prevention of Significant Deterioration and Nonattainment Area Permitting (EPA, 1990). It is commonly referred to as the EPA Puzzle Book. There are five basic steps to EPA's "top-down" BACT process for evaluation of pollutant emission control technologies. These steps include the following:

- Step 1 - Identify all available control technologies for each pollutant subject to review.

- Step 2 - Eliminate all technically infeasible control technologies.

- Step 3 - Rank the remaining control technologies by control effectiveness.

- Step 4 - Evaluate the feasible control technologies, beginning with the most efficient, with respect to economic, energy, and environmental impacts.

- Step 5 - Select as BACT the most effective control technology that is not rejected based on adverse economic, environmental, and/or energy impacts. 
Each step is described below:

Step 1: Identifies all commercially available toxic air emission control options. This step involves a search for available technologies that can reduce the emission levels for the toxic contaminants of concern. Technologies required under previously completed lowest achievable emission rate (LAER) determinations are available for BACT purposes and are also included as control alternatives. They usually represent the "top" alternative (the highest emission reduction). The information sources used to identify control technologies include:

- Previous BACT and tBACT demonstrations.

- EPA's reasonably available control technology (RACT)/BACT/LAER Clearinghouses.

- Regulatory authorities.

- Federal, State and local new source review (NSR) permits.

- Control technology vendors.

- Literature search.

- Internet Searches.

- Similar commercial government applications.

Step 2: Eliminates all of the above identified technically infeasible options and develops a short list of control technologies for further analysis. Screening criteria is applied to eliminate any control technology that is not available (cannot be obtained commercially) or not applicable (able to be reasonably installed and operated for control of tank farm process emissions). The determination of feasibility is based on evaluating vendor specifications and commercial or government application experience data for available control technologies previously identified. If a control technology has been installed and operated successfully on emissions with similar chemical and physical characteristics to those from processes that are being evaluated, it is demonstrated and is technically feasible.

The screening criteria developed for application to the suite of control technologies are as follows:

- The control technology has not been demonstrated at sufficient scale or removal efficiency for the application.

- The control technology introduces additional hazards above and beyond the primary control hazard.

- The control technology uses materials of construction that are unsuitable in a radiation field anticipated during operations or impact the integrity of materials of construction (i.e., corrosion) and no suitable alternative materials can be substituted.

- The control technology would be very difficult to modify for applicable field operations and maintenance activities anticipated during operations.

- Control technology would generate secondary waste streams.

- The control technology requires testability requirements where extraordinary measures would be required to ensure operational performance.

Step 3: Ranks the remaining control technologies in order of effectiveness for each unabated emission off gas stream under evaluation. The most effective control technology is ranked at the top.

Step 4: Evaluates economic impacts for highly-ranked applicable technologies for each unabated emission off gas stream analyzed. The purpose of the economic evaluations is to determine and 
compare "cost reasonableness" (\$/ton pollutant reduction) of the highly ranked technologies, in order, to determine whether impacts were acceptable. The economic analyses include factors for environmental impacts (e.g., secondary waste treatment, disposal costs) and energy impacts (e.g., utility costs). These economic impacts are based on average and incremental cost effectiveness or reasonableness of these analyses, expressed as cost per ton of pollutant removed. In addition, impacts on worker health and safety, such as labor for equipment maintenance, can be included.

Step 5: The control technology with the highest control efficiency is evaluated first for tBACT. If this technology is found to have acceptable energy, environmental, or economic impacts, then it is proposed as tBACT and no further analysis is necessary. If the top technology is shown to be inappropriate, based on energy, environmental, or economic impacts, the applicant must fully document the justification for this conclusion. Then the next most effective control technology on the list becomes the new candidate and is similarly evaluated. This process continues until the technology under consideration cannot be eliminated due to energy, environmental, or economic impacts, which would demonstrate the technology to be appropriate as tBACT.

\section{General Approach to Economic Impact Evaluation}

An economic determination is made whether there is any unacceptable environmental, energy, or economic impacts for the highest ranked technology. If there are no unacceptable impacts, then the highest ranked technology is proposed as tBACT for each unabated off gas stream. Economic evaluations are performed consistently across all technologies, and are rough order of magnitude cost estimates and employ the procedure found in the Office of Air Quality Planning and Standards Air Pollution Control Cost Manual, Sixth Edition (EPA, 2002). The results of the economic analyses are included as cost tables.

The economic impacts of the control technology options are evaluated by calculating the cost effectiveness. This calculation is performed by estimating the total annualized cost of control (\$/yr) and dividing by the annual amount of emission reduction that would be achieved (tons/yr). The resulting cost effectiveness value (\$/ton) is compared to costs for similar applications and to guidance provided by regulatory agencies.

Typically, cost effectiveness evaluations are compared to survey values compiled by Federal and State regulatory agencies. In general, tBACT cost effectiveness for pollutants are considered relative to "Plateau" and "Ceiling" values. Plateau level values are those below which a control technology is rarely thrown out as economically unjustifiable. The tBACT cost Ceiling value is a value above which a control technology is rarely judged economically justifiable. No similar cost guidance has been developed for $\mathrm{tBACT}$. However, previous $\mathrm{tBACT}$ evaluations submitted from Hanford and approved by Ecology have used an additional factor for determination of cost ceiling values. These previous tBACT evaluations are as follows:

- Letter July 31, 2007, J.A. Hedges to S. Olinger, Approval of Criteria and Toxic Emissions Notice of Construction (NOC) Application, Hanford Single-Shell Tank Waste Retrieval, Approval Order DE05NWP-002 Rev. 2.

- Letter October 12, 2005, M.A. Wilson to R.J. Schepens, Approval of Criteria and Toxic Emissions Notice of Construction (NOC) Application for Operations of Waste Retrieval Systems in Single-Shell Tank (SST) Farms as Supplemented with C Farm Exhauster Operation Incorporating C-200 Series Tanks and Aggregated Exhaust Points for the 241-C Tank Farm, Approval Order DE05NWP-002, Rev. 1. 
- Letter February 18, 2005, M.A. Wilson to R.J. Schepens, Approval of Non-Radioactive Air emissions Notice of Construction (NOC) for Operation of New Ventilation Systems in AN and AW Tank Farms, Approval Order DE05NWP-001.

The maximum previous plateau tBACT value was $\$ 5,700 /$ ton and the maximum ceiling value was $\$ 10,500 /$ ton. The additional tBACT factors used in the previous tBACT evaluations were based upon two options. These options took into account the toxicity and carcinogenicity of the various TAPs to scale the tBACT cost factors to reflect the hazards of these pollutants based upon either the classification of each TAP (Class A or B) or the ASIL associated with each TAP.

Option 1: The first option used in the previous tBACT evaluations refers to the Class A and Class B TAP classification defined in the previous (prior to June 20, 2009) WAC 173-460 regulation. For Class A TAPs, the "Plateau" and "Ceiling" values were multiplied by a factor of 10. For Class B TAPs, the "Plateau" and "Ceiling" values were multiplied by a factor of 5 .

As of June 20, 2009, the revised WAC 173-460-150 no longer uses the Class A and Class B designations for identification of TAPs to use this method, however, it was noted that the previous Class A TAPs had, for the most part, annual averaging periods and Class B TAPs had 24-hour averaging periods. The current version of the regulations use annual, 24-hour, and hourly averaging periods and no longer designate Class A and B. None of the TAPs with hourly averaging periods were above the de minimis.

The "Plateau" and "Ceiling" values used for all current TAPs with annual averaging periods were multiplied by a factor of 10. Table 2-1 takes the highest "Plateau" of $\$ 5,700$ and the "Ceiling" of $\$ 10,500$ values from the previous tBACTs and multiplies these by the factors of 5 and 10 to demonstrate this $\mathrm{tBACT}$ adjustment described above.

\begin{tabular}{l|l|l|l}
\hline \multicolumn{5}{|c|}{ Table 2-1. tBACT Cost Factors } \\
$\begin{array}{l}\text { Method } \\
\text { Cost Factor }\end{array}$ & $\begin{array}{l}\text { Cost Effectiveness Threshold (\$/ton) } \\
\text { Plateau }\end{array}$ & Ceiling \\
\hline Toxic Air Pollutants (TAP) Classification & & $\$ 105,000$ \\
\hline Annual Averaging TAP & 10 & $\$ 57,000$ & $\$ 52,500$ \\
\hline 24-hour Averaging TAP & 5 & $\$ 28,500$ & \\
\hline
\end{tabular}

Option 2: The second option used in the previous tBACT evaluations for assessing tBACT cost effectiveness was based on individual pollutant ASILs and involves calculating a pollutantspecific cost factor using the following:

$$
\text { Cost Factor }=\log _{10}(27,000 \div \text { ASIL })
$$

The cost effectiveness thresholds for tBACT "Plateau" and "Ceiling" values were then determined for each pollutant by multiplying the maximum pollutant "Plateau" and "Ceiling" values by the pollutant-specific cost factor. Table 2-2 demonstrates these cost factors for all pollutants determined to be above the de minimis for purposes of this tBACT evaluation.

Designated Methodology: All of the tBACT cost factors from Option 2 were under a factor of 10 , except for dimethyl mercury. A multiplier of 10 was determined to be the upper limit for adjustment of the previously used tBACT "Plateau" and "Ceiling" values. The upper and bounding "Plateau" and "Ceiling" values used for this tBACT evaluation were then $\$ 57,000 /$ ton and $\$ 105,000 /$ ton respectively. 
Table 2-2. ASIL Based Cost Factor Calculations for Com pounds Above De Minimis Thresholds

Compound Name

ASIL

Ammonia $\left(\mu \mathrm{g} / \mathbf{m}^{3}\right)$

ASIL Based Cost Factor

Particulate Metal Compounds

70.8

(Cost Factor $=\log 10(27,000 /$ ASIL $)$

Arsenic \& Inorganic Arsenic Compounds

0.000303

2.6

Beryllium \& Compounds (NOS)

0.000417

7.9

Cadmium \& Compounds

0.000238

7.8

Chromium Hexavalent: Soluble, except Chromic Trioxide

Cobalt

Manganese \& Compounds

$6.67 \mathrm{E}-6$

8.1

$6.67 \mathrm{E}-6 \quad 9.6$

Mercury Compounds

Mercury, Elemental

$0.04 \quad 5.8$

Dimethyl Mercury

0.09

5.5

Organic Compounds

1,1,2,2-Tetrachloroethane

$1.00 \mathrm{E}-99$

103.4

1,1,2-Trichloroethane

0.0172

1,2-Dibromoethane

$0.0625 \quad 5.6$

1,2-Dichloroethane

0.0141

1,2-Dichloropropane

0.0385

0.1

1,3-Butadiene

0.00588

1,4-Dichlorobenzene

0.0909

1,4-Dioxane

0.13

Acetaldehyde

Acrylic Acid

0.37

Acrylonitrile

1

Benzene

0.00345

Benzyl Chloride

0.0345

0.0204

Carbon Tetrachloride

0.0238

Chloroform

0.0435

6.2

Dichloromethane

1

Ethylbenzene

Ethylene oxide

0.4

Hexachlorobutadiene

0.0114

0.0455

0.0909

Hexachloroethane

0.0294

Naphthalene

$1.00 \mathrm{E}-04$

6.3

n-Nitrosodiethylamine

0.000217

0.000323

n-Nitroso-di-n-butylamine

0.0005

n-Nitrosodi-n-propylamine

n-Nitrosomorpholine

0.000526

n-Nitroso-n-methylethylamine

0.000159

0.00167

n-Nitrosopyrrolidine

Perchloroethylene

Polychlorinated Biphenyls (PCBs)

Trichloroethylene

Vinyl Chloride

0.169

0.00175

0.5

0.0128

5.8

5.5

5.3

4.9

4.4

6.9

5.9

6.1

6.1

5.8

4.4

4.8

6.4

5.8

5.5

6.0

8.4

8.1

7.9

7.7

7.7

8.2

7.2

5.2

7.2

4.7

6.3

Source: RPP-RPT-44009 Rev 1, Spreadsheet Description Document for Non-Radiological Air Source Term for 241-SY Farm and 241-AP Farm Primary Ventilation Systems Upgrades (May 2010) and SVF-1821, Rev 1, Non-Rad Air Source Term for 241SY Farm and 241-AP Farm Primary Ventilation System Upgrades.xlsm (May 2010) 


\subsection{Double Shell Tank System Primary Ventilation System Description and} Associated Source Term

\section{System Description}

Figure 3-1 shows overall configuration of the Hanford tank farms that are located in the 200 East and 200 West area of the Hanford Site. The DST farms are used for storage, treatment, retrieval, and transfer of the tank waste, including future transfers to the WTP.

Each DST farm currently exhausts emissions through a primary ventilation system. These primary ventilation systems serve as a containment system for radioactive particulates present in the tank headspace, vent flammable gases and vapors that evolve from the liquid surface in the DSTs, and remove heat. The system operates by drawing outside air into and through the tank headspace. After the air leaves the headspace, the ventilation system conditions the outlet stream to remove entrained moisture, reduces relative humidity, and filters particulates. During exhaust discharge to atmosphere through the stack, the exhaust is monitored and sampled for radioactive particulates.

Ventilation system upgrades for each of the DST farms are needed for operational reliability and to support future waste feed delivery for the WTP. The primary ventilation system upgrades includes design, fabrication, installation, and construction acceptance testing. Each Tank Farm will have two parallel systems to include exhausters, deentrainer, heater, pre-filter, HEPA filter trains (two in series), fan, exhaust stack, ventilation system ducting, and stack and associated stack monitoring equipment including record samplers, continuous air monitors and other detectors.

\section{Figure 3-1. Location of Tank Farms in 200 East and 200 West Areas of the Hanford Site}

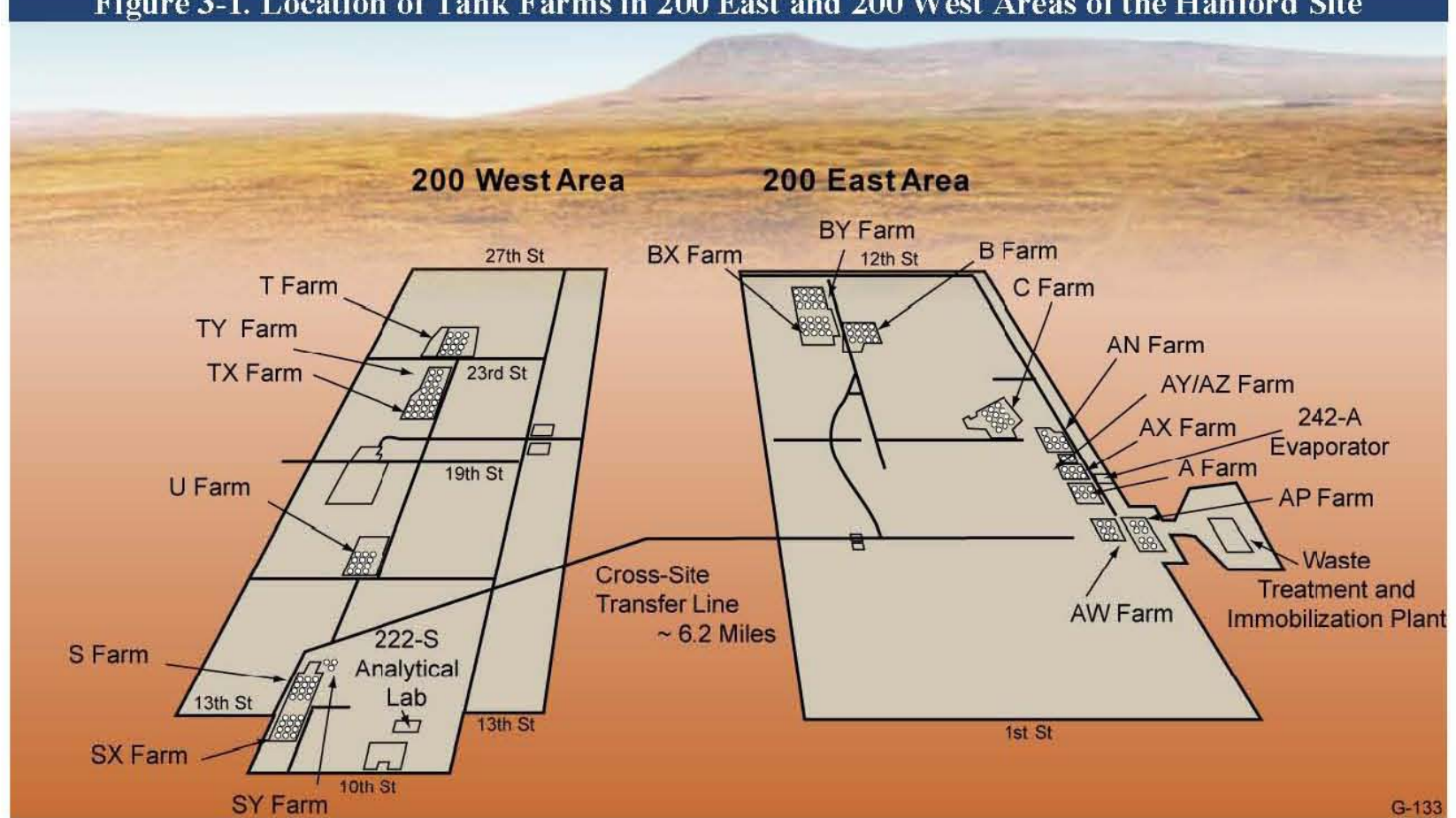


Currently, the primary ventilation system requirements are:

- Remove heat from the primary tank by removing water vapors from the headspace.

- Confine materials by maintaining vacuum conditions within the tank.

- Remove moisture from the exhaust air by condensation and de-entrainment.

- Remove radioactive particulate materials from the gaseous effluent.

- Remove flammable gases from the primary tank vapor space.

The major components of the current primary ventilation subsystem include: filtration, fan/blower, stack, and monitoring and control instruments as shown in Figure 3-2. The exhaust fans maintain a negative pressure on the tanks, thereby eliminating fugitive emissions, maintain an adequate airflow for cooling of the tanks, and remove any accumulated flammable gases. In the event of a failure of the operating filtration train and/or exhaust fan, the standby filter bank and exhaust fan are activated.

An exhaust air cooler is optionally placed in the flow stream between the storage tanks and the deentrainer (moisture separator). The function of the cooler is to reduce the temperature of the air stream so as not to exceed the maximum operating temperature of the stack monitoring and control system. Moisture is removed by the primary ventilation system via the deentrainer. Collected condensate is returned to a designated DST in the farm. The system reduces the relative humidity by heating the exhaust air stream before it enters the prefilter and the HEPA filters. The prefilter removes the large particulates and reduces the load on the HEPA filters.

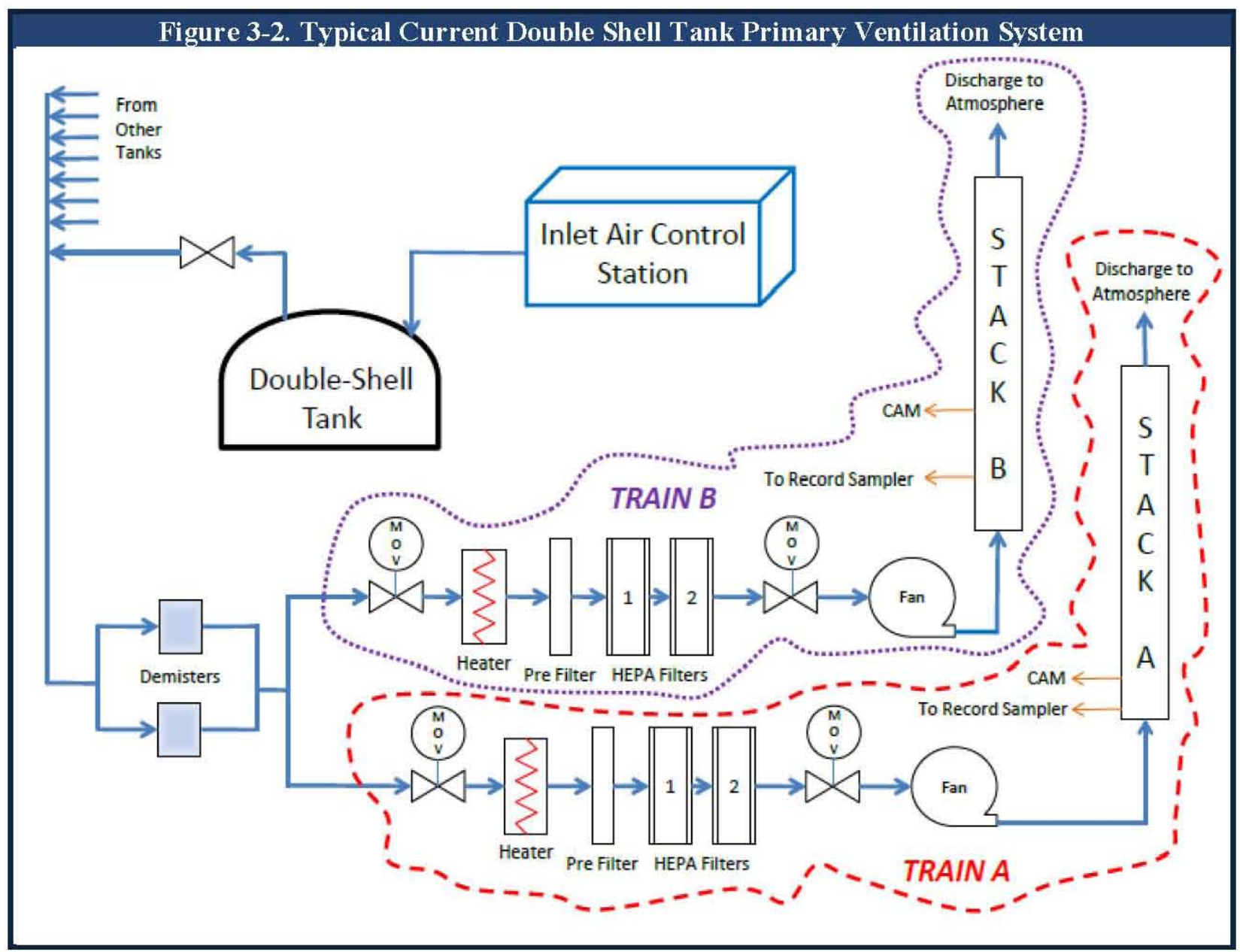


Two HEPA filters are used in series; these filters are test qualified by the manufacturer to comply with ASME AG-1, Section FC, and remove $99.97 \%$ of particulate greater or smaller than 0.3 microns.

The exhauster train has a centrifugal fan, which induces the air flow through the DSTs to the HEPA filters. It is located downstream of the HEPA filters and discharges into the stack. Each train is self contained; each exhaust system has its own stack.

\section{Source Term}

The source term data used for this tBACT demonstration is documented in RPP-RPT-44009 and $\mathrm{SVF}-1821$. The source term assesses potential release rates of hazardous chemicals to doubleshell tank farm ventilation exhausters during waste storage operations and operations supporting waste feed delivery to the WTP. The source term is bounded by potential releases of hazardous chemicals from 241-AP Farm as discussed below. The following methodology was used to determine the Hanford DST farm source term:

- Compare WAC-173-460-150, Table of ASIL, SQER and De Minimis Values and Tank Waste Information Network System (TWINS) listed substances by common name and by Chemical Abstract Service registration number (CAS\#). CAS\#s were used to sort and match the listing of CAS\#s found in TWINS.

- TWINS data is for both SSTs and DSTs

- Extract common entries for evaluation as a TAP and calculate release rates for each by multiplying measured headspace concentrations by the headspace ventilation flow rate.

- Equate potential release rate of each to the highest calculated release rate.

- Increase potential release rates for tanks with waste disturbing activity (waste transfer or waste mixing operations) by a factor of ten to account for the increased headspace concentration. Assume that up to two tanks in a farm have waste disturbing activities in progress and that the waste in the remaining tanks experience quiescent conditions.

- Select the DST Farm with the largest number of tanks (e.g. 241-AP Farm with eight tanks).

- Determine the source term multiplier for the selected tank farm [for 241-AP Farm: two tanks with waste disturbing activity $(2 \times 10=20)$ plus six tanks with quiescent waste conditions $(6 \times$ $1=6$ ) for a total source term multiplier of 26].

- The bounding DST farm source term for each hazardous chemical is equal to the highest calculated release rate multiplied by 26 .

Approximately 90 chemical compounds were identified as TAPs. Of the 90 identified TAPs, 41 were identified to be above the de minimis values in accordance with WAC-173-460-150 (Table of ASIL, SQER, and De Minimis Values). These 41 TAPs are listed in Table 3-1. Based on these 41 compounds, four tBACT analyses (reflecting similar physical and chemical properties) are required to assess emission control technologies for all TAPs above de minimis thresholds:

- Toxic organic compounds (Section 4.0)

- Ammonia (Section 5.0)

- Mercury compounds (Section 6.0)

- Particulate metal compounds (Section 7.0). 


\begin{tabular}{|c|c|c|c|c|}
\hline Compound Name & $\begin{array}{l}\text { Chemical } \\
\text { Abstract \# }\end{array}$ & $\begin{array}{l}\text { Averaging } \\
\text { Period }\end{array}$ & $\begin{array}{l}\text { Release Rate } \\
\text { (lb/avg. period) }\end{array}$ & $\begin{array}{l}\text { De Minimis Release } \\
\text { Rate (lb/avg. period) }\end{array}$ \\
\hline Ammonia & $7664-41-7$ & $24-\mathrm{hr}$ & $7.19 \mathrm{E}+01$ & 0.465 \\
\hline \multicolumn{5}{|l|}{ Toxic Organic Compounds } \\
\hline 1,1,2,2-Tetrachloroethane & $79-34-5$ & Year & $1.95 \mathrm{E}+01$ & 0.165 \\
\hline 1,1,2-Trichloroethane & $79-00-5$ & Year & $1.55 \mathrm{E}+01$ & 0.6 \\
\hline 1,2-Dibromoethane & $106-93-4$ & Year & $2.09 \mathrm{E}+00$ & 0.135 \\
\hline 1,2-Dichloroethane & $107-06-2$ & Year & $4.27 \mathrm{E}+01$ & 0.369 \\
\hline 1,2-Dichloropropane & $78-87-5$ & Year & $1.25 \mathrm{E}+00$ & 0.959 \\
\hline 1,3-Butadiene & $106-99-0$ & Year & $5.22 \mathrm{E}+00$ & 0.0564 \\
\hline 1,4-Dichlorobenzene & $106-46-7$ & Year & $1.63 \mathrm{E}+00$ & 0.872 \\
\hline 1,4-Dioxane & $123-91-1$ & Year & $1.84 \mathrm{E}+01$ & 1.25 \\
\hline Acetaldehyde & $75-07-0$ & Year & $1.08 \mathrm{E}+02$ & 3.55 \\
\hline Acrylic Acid & $79-10-7$ & $24-\mathrm{hr}$ & 4.67E-02 & 0.00657 \\
\hline Acrylonitrile & $107-13-1 \mathrm{M}$ & Year & 3.23E-01 & 0.0331 \\
\hline Benzene & $71-43-2$ & Year & $4.27 \mathrm{E}+01$ & 0.331 \\
\hline Benzyl Chloride & $100-44-7$ & Year & $3.51 \mathrm{E}-01$ & 0.196 \\
\hline Carbon Tetrachloride & $56-23-5$ & Year & $4.30 \mathrm{E}+01$ & 0.228 \\
\hline Chloroform & $67-66-3$ & Year & $4.30 \mathrm{E}+01$ & 0.417 \\
\hline Dichloromethane & $75-09-2$ & Year & $2.92 \mathrm{E}+02$ & 9.59 \\
\hline Ethylbenzene & $100-41-4$ & Year & $3.70 \mathrm{E}+01$ & 3.84 \\
\hline Ethylene oxide & $75-21-8$ & Year & 2.03E-01 & 0.109 \\
\hline Hexachlorobutadiene & $87-68-3$ & Year & $3.04 \mathrm{E}+01$ & 0.437 \\
\hline Hexachloroethane & $67-72-1$ & Year & $4.41 \mathrm{E}+01$ & 0.872 \\
\hline Naphthalene & $91-20-3 \mathrm{M}$ & Year & $3.41 \mathrm{E}-01$ & 0.282 \\
\hline n-Nitrosodiethylamine & $55-18-5$ & Year & $5.08 \mathrm{E}-02$ & 0.000959 \\
\hline n-Nitrosodimethylamine & $62-75-9$ & Year & $6.94 \mathrm{E}+01$ & 0.00208 \\
\hline n-Nitroso-di-n-butylamine & $924-16-3$ & Year & $5.08 \mathrm{E}-02$ & 0.0031 \\
\hline n-Nitrosodi-n-propylamine & $621-64-7$ & Year & $5.08 \mathrm{E}-02$ & 0.0048 \\
\hline n-Nitrosomorpholine & $59-89-2$ & Year & $2.35 \mathrm{E}-01$ & 0.00505 \\
\hline n-Nitroso-n-methylethylamine & $10595-95-6$ & Year & $5.08 \mathrm{E}-02$ & 0.00153 \\
\hline n-Nitrosopyrrolidine & $930-55-2$ & Year & $5.08 \mathrm{E}-02$ & 0.016 \\
\hline Perchloroethylene & $127-18-4$ & Year & $4.24 \mathrm{E}+01$ & 1.62 \\
\hline Polychlorinated Biphenyls (PCBs) & $1336-36-3$ & Year & $5.34 \mathrm{E}-01$ & 0.0168 \\
\hline Trichloroethylene & $79-01-6$ & Year & $4.27 \mathrm{E}+01$ & 4.8 \\
\hline Vinyl Chloride & $75-01-4$ & Year & $4.30 \mathrm{E}+01$ & 0.123 \\
\hline \multicolumn{5}{|l|}{ Mercury Compounds } \\
\hline Mercury, Elemental & $7439-97-6$ & $24-\mathrm{hr}$ & $1.43 \mathrm{E}-03$ & 0.000591 \\
\hline Dimethyl Mercury & $593-74-8$ & 24-hr & $2.96 \mathrm{E}-06$ & $1.00 \mathrm{E}-99$ \\
\hline \multicolumn{5}{|l|}{ Particulate Metals Compounds } \\
\hline $\begin{array}{l}\text { Arsenic \& Inorganic Arsenic } \\
\text { Compounds }\end{array}$ & $7440-38-2$ & Year & $1.72 \mathrm{E}+00$ & 0.00291 \\
\hline Beryllium \& Compounds (NOS) & $7440-41-7$ & Year & $8.61 \mathrm{E}-02$ & 0.004 \\
\hline Cadmium \& Compounds & $7440-43-9$ & Year & $8.61 \mathrm{E}-01$ & 0.00228 \\
\hline $\begin{array}{l}\text { Chromium Hexavalent: Soluble, } \\
\text { except Chromic Trioxide }\end{array}$ & $7440-47-3$ & Year & $2.63 \mathrm{E}+00$ & $6.40 \mathrm{E}-05$ \\
\hline Cobalt & $7440-48-4$ & 24-hr & 4.70E-03 & 0.000657 \\
\hline Manganese \& Compounds & $7439-96-5$ & 24-hr & $4.70 \mathrm{E}-03$ & 0.000263 \\
\hline
\end{tabular}


4.0 IdENTIFICATION AND EVALUATION OF EMISSION CONTROL TECHNOLOGY OPTIONS FOR Toxic ORganic COMPOUNDS

This section covers the detailed tBACT evaluation for toxic organic compound emissions for the DST farm system. Toxic organic compound emissions have been evaluated and defined by RPPRPT-44009 and SVF-1821. Thirty-two (32) different, toxic, organic compounds have been estimated to be above their de minimis levels (see Section 3.0, Table 3-1 as defined in RPP-RPT44009 and SVF-1821). All toxic organic compounds will be treated as a group of TAPs because they have similar physical and chemical properties and similar control technologies. The total annual toxic organic compounds emitted from the operations of a primary ventilation system of a DST farm are estimated to be 0.48 tons/year (derived from Table 3-1).

\section{Step 1: Emission Control Technologies Identified for Toxic Organic Compounds} The following emission control technologies have been identified for the destruction and/or removal of toxic organic compound emissions.

- Activated carbon adsorption.

- Wet scrubber absorption.

- Thermal catalytic oxidation.

- Thermal non-catalytic oxidation

\section{Step 2: Elimination of Technically Infeasible Options/Development of Short List for Toxic Organic Compounds}

Qualitative screening and elimination criteria were developed for the selective elimination of control technologies evaluated to be technically infeasible or not applicable for treatment of toxic organic compound emissions from the primary ventilation system in DST farm processes. The screening criteria were applied for the suite of control technologies for toxic organic compounds listed above and are shown in Table 4-1. The only identified emission control technology that was determined to be technically infeasible and eliminated for this application is thermal catalytic oxidation.

\begin{tabular}{|c|l|l|}
\hline \multicolumn{2}{c|}{ Table 4-1. Toxic Organic Compounds - Potential tBACT } \\
\hline Control & Description & Screening Results \\
\hline $\mathbf{1}$ & Activated Carbon Adsorption & Applicable \\
\hline $\mathbf{2}$ & Wet Scrubber Absorption & Applicable \\
\hline $\mathbf{3}$ & Thermal Catalytic Oxidizer & Eliminated \\
\hline $\mathbf{4}$ & Thermal Non-Catalytic Oxidation & Applicable \\
\hline
\end{tabular}

Thermal Catalytic Oxidation: Thermal catalytic oxidation can be used to reduce volatile or toxic organic compound emissions from a variety of sources. Generally high flow, low concentration applications are best suited to produce high removal efficiencies for this technology. Particulates or halogenated volatile organic compounds and heavy metals can clog the packed bed or poison or deactivate the catalyst reducing the design life of the unit. Specific poisons include halogenated compounds, mercury, arsenic, sulfur, sodium, and calcium. Many of these compounds are found in the tank waste in high concentrations. 


\section{Step 3: Rank Remaining Control Technologies by Control Effectiveness}

Effectiveness is defined by the ability of the control technology to reduce the post treatment emission rate for a given TAP or group of TAPs. The short list of tBACT technologies for toxic organic compounds in order of removal efficiency is provided in Table 4-2. The technologies with a removal efficiency of $99 \%$ or greater were down-selected for further tBACT economic evaluation which include activated carbon adsorption and thermal noncatalytic oxidation. Nevertheless, a general technology overview of wet scrubber absorption is described below for evaluation completeness.
Table 4-2. tBACT Ranking by Effectiveness for Control of Toxic Organic Compounds

Ranking/Technology

1a. Activated Carbon Removal Efficiency Adsorption

1b. Thermal Non-Catalytic $\quad 99 \%$ Oxidation 3. Wet Scrubber Absorption $\quad 70-90 \%$

Activated Carbon Adsorption: The principal use of activated carbon as a control technology is for the removal of VOCs such as hydrocarbons, solvents, toxic gases and organic based odors. In addition, chemically impregnated activated carbons can be used to control certain inorganic pollutants such as hydrogen sulfide, mercury, or radon. When properly applied, the adsorption process will remove pollutants for which it is designed, to virtually nondetectable levels. Carbon adsorption is equally effective on single component emissions as well as complex mixtures of pollutants.

\section{Figure 4-1. Typical Adsorption Isotherm (Benzene)}

\section{NUCON}

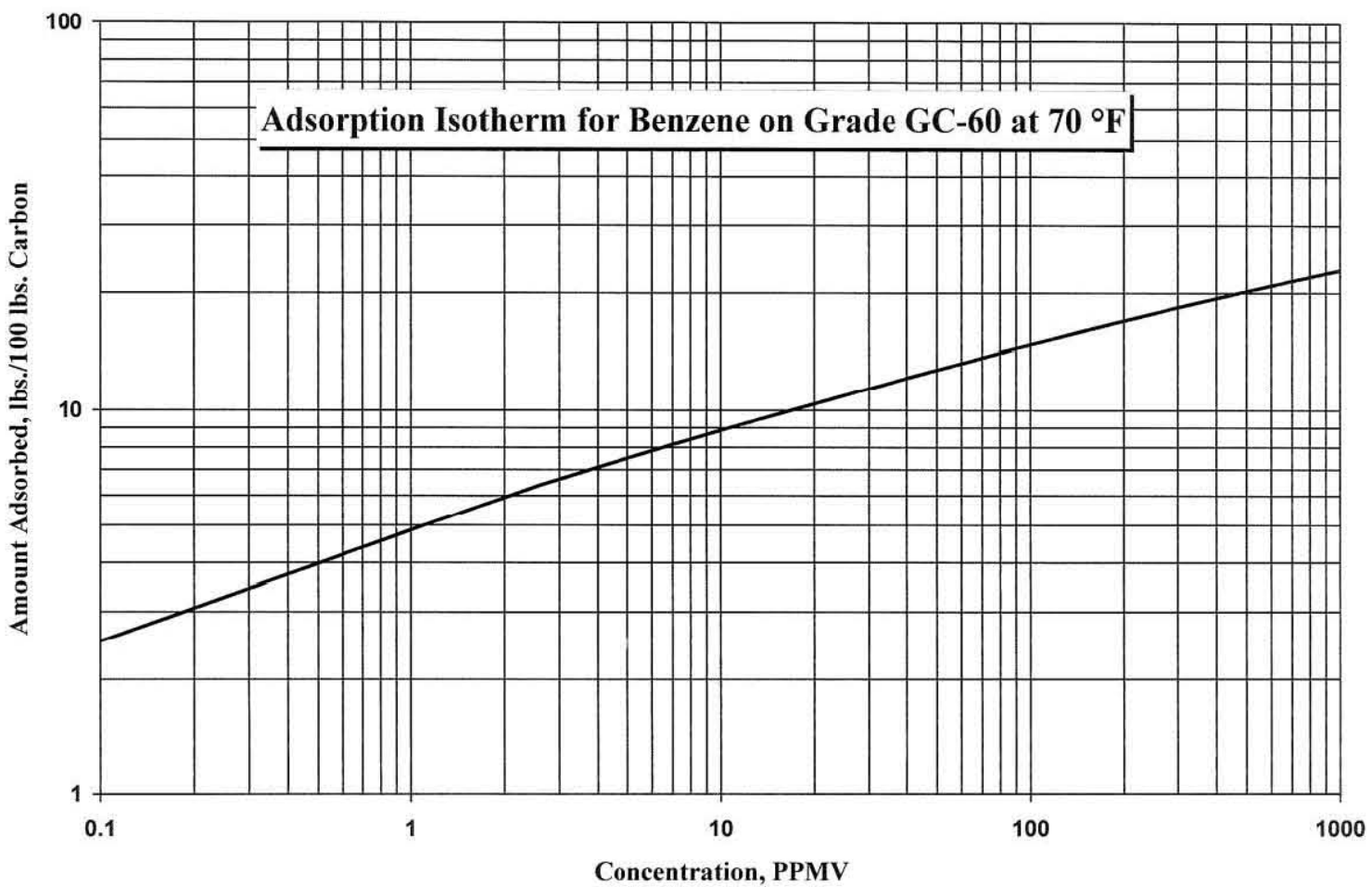


Physical adsorption is dependent on the characteristics of the pollutant to be adsorbed, the temperature of the gas stream to be processed, and the concentration of the contaminant in the gas stream. The adsorption capacity for a particular pollutant represents the amount of the pollutant that can be adsorbed on a unit weight of activated carbon consumed at the conditions present in the application. Typical adsorption capacities for moderately adsorbed compounds range from 5 to 30 percent of the weight of the carbon. A typical carbon adsorption isotherm (i.e., benzene) is shown in Figure 4-1. This figure shows that the adsorption of a compound is inversely proportional to the concentration when plotted on a log-log scale.

Activated carbon adsorption is applicable to low boiling point, small toxic, and volatile organic molecules. Large toxic or organic molecules are very difficult to remove from an activated carbon bed either by steam or by hot inert gas stripping and frequently result in decomposition or permanent plugging of the carbon bed. When a small fraction of the toxic organic compound "high boilers" (large molecular weight, high boiling point compounds) are present, a sacrificial guard bed is used to protect the main regenerable beds from poisoning. The guard bed is replaced when breakthrough occurs. Large toxic or organic molecule activated carbon adsorption is economical only when the recoverable toxic organic compound is the significant fraction of the total toxic organic compounds with a small percentage of high boilers.

For toxic or volatile organic compounds at low concentration (below $100 \mathrm{vppm}$ ), the typical control technology is fixed bed adsorption on activated carbon and disposal of carbon off site. In most cases, the adsorbent can be "reactivated" under similar conditions as the "activation process ( $\sim 1000 \mathrm{C}$ steam/air environment) where the adsorbed compounds are destroyed and the carbon is returned to near its original capacity. In addition, fixed adsorption is analogous to chromatography, the various organic compounds adsorbing have a significant impact on the adsorption capacity of other organic molecules, due to both displacement and to near permanent deposition on the carbon bed. Thus, while the adsorbent may indicate a relatively high pure component adsorption capacity for a particular component, when the gas stream has a large variety of organic molecule sizes and boiling points, the equilibrium capacity indicated by adsorption isotherms for that component cannot be approached.

As an example, a pure component isothermal capacity of $10 \mathrm{wt} \%$ may be reduced to as low as $0.1 \mathrm{wt} \%$ in a multi-component system due to displacement by other components of the gas stream or by the "plugging" of otherwise available surface by high molecular weight compounds. The effect of "co-adsorbates" in the individual breakthrough adsorption time of the toxic organic compounds was estimated by the National Research Council (NRC) in relation to chemical agent incineration effluent control in a dynamic system. (NRC 1999, The Disposal of Activated Carbon from Chemical Agent Disposal Facilities) and is shown in Table 4-3 (on next page).

Also, many emission source terms are defined with many safety factors, typically increasing the assumed concentration of the toxic organic compounds in the inlet gas stream, often by as much as an order of magnitude. Adsorption capacity is concentration dependent and an order magnitude decrease in organic compound concentration typically results in halving the adsorption capacity. Therefore, using an inflated source term for toxic organic compound concentrations, results in an undersized adsorption system. 


\begin{tabular}{|c|c|c|c|}
\hline $\begin{array}{l}\text { Volatile Organic } \\
\text { Compound }\end{array}$ & $\begin{array}{l}\text { Estimated Initial } \\
\text { Concentration }(\mathrm{ng} / \mathrm{m} 3)^{\mathrm{a}}\end{array}$ & $\begin{array}{l}\text { Estimated Breakthrough } \\
\text { Time as Single Component }\end{array}$ & $\begin{array}{l}\text { Estimated Time for Multi- } \\
\text { Component PFS Flue Gas }\end{array}$ \\
\hline Benzene & 90,000 & 2.4 years & 14.2 hours \\
\hline Carbon tetrachloride & 35,000 & 4.1 years & 7.1 minutes \\
\hline Chloroform & 22,000 & 2.5 years & 5.7 hours \\
\hline Vinyl chloride & 4,500 & 1.7 days & 9.5 minutes \\
\hline \multicolumn{4}{|c|}{$\begin{array}{l}\text { Notes: }{ }^{a} \text { Bed dimensions }=214 \text { square feet, } 1 \text { foot deep, } 3,030 \mathrm{~kg} \text { of carbon } \\
{ }^{b} \text { Calculated based on D-R equation assuming complete saturation of filter at } 135^{\circ} \mathrm{F} \\
\text { 'Based on multi-component computer model, } 135^{\circ} \mathrm{F}, 67 \text { percent relative humidity } \\
\text { Source: National Research Council, } 1999\end{array}$} \\
\hline
\end{tabular}

Furthermore, due to mass transfer limitations, only very large adsorbent beds approach the equilibrium capacity under dynamic conditions. The length of the mass transfer zone (MTZ) is again highly dependent on the properties of both the adsorbent structure (macro and micro porosity) and the properties of the organic compounds. This is further complicated in case of variable concentration of organic compounds entering the adsorbent bed, because both adsorption and desorption mass transfer needs to be considered. In most cases, the desorption MTZ is significantly longer than the adsorption MTZ. These factors establish the minimum bed depth (in the flow direction) criterion for adsorbent bed design. Typically, the minimum bed depth, for long term use applications, should be several orders of magnitude longer than the MTZ. Therefore, adsorbent beds cannot be designed solely on the adsorbent mass basis, the geometry is also important. If the bed depth is shorter than one MTZ for a particular compound, then instantaneous breakthrough of the organic compound will occur. (Schweitzer, 1988, Handbook of Separation Techniques for Chemical Engineers, $2^{\text {nd }}$ Edition).

In summary, activated carbon has been shown to be applicable for treatment of a wide variety of environmental pollutants. It is a proven technology that is simple to install and easy to operate and maintain. Capital costs are among the least expensive for most alternative treatment technologies. Operating costs are primarily related to the amount of activated carbon consumed in the adsorption process.

Thermal Non-Catalytic Oxidation: Thermal non-catalytic oxidation is the process of oxidizing combustible materials by raising the temperature of the material above its auto-ignition point in the presence of oxygen, and maintaining it at high temperature for sufficient time to complete combustion to carbon dioxide and water. Time, temperature, turbulence (for mixing), and the availability of oxygen all affect the rate and efficiency of the combustion process. These factors provide the basic design parameters for oxidation systems (ICAC 1999, Institute of Clean Air Companies, Control Technology Information - Thermal Oxidation). 
Typical thermal oxidation design efficiencies range from 98 to $99.99 \%$ and above, depending on system requirements and characteristics of the pollutants (EPA 1992; Control Techniques for Volatile Organic Emissions from Stationary Sources; EPA 1996, OAQPS Control Cost Manual). Thermal oxidation often the best choice when high efficiencies are needed and the waste gas is above $20 \%$ of the Lower Explosive Limit (LEL). Oxidation units, in general, are not recommended for controlling gases containing halogen- or sulfur-containing compounds because of the formation of highly corrosive acid gases. It may be necessary to install a post-oxidation acid gas treatment system in such cases, depending on the outlet concentration to reduce increased corrosion rates (EPA, 1996). Thermal incinerators are also not generally cost-effective for low-concentration, high-flow organic vapor streams (EPA 1995, Control and Pollution Prevention Options for Ammonia Emission).

Wet Scrubber Absorption: Wet scrubber absorption is widely used as a raw material and/or product recovery technique in separation and purification of gaseous streams containing high concentrations of volatile and toxic organic compounds, especially water soluble compounds such as methanol, ethanol, isopropanol, butanol, acetone, and formaldehyde (Croll Reynolds 1999, Croll Reynolds Company, Inc., web site http://www.croll.com). However, as an emission control technique, it is much more commonly employed for controlling inorganic gases than for volatile or toxic organic compounds. When using absorption as the primary control technique for organic vapors, the spent solvent must be easily regenerated or disposed of in an environmentally acceptable manner (EPA 1991, Control Technologies for Hazardous Air Pollutants). When used for particulate control, high concentrations can clog the bed, limiting these devices to controlling streams with relatively low dust loadings (EPA 1998, Stationary Source Control Techniques Document for Fine Particulate Matter).

Physical absorption depends on properties of the gas stream and liquid solvent, such as density and viscosity, as well as specific characteristics of the pollutant(s) in the gas and the liquid stream (e.g., diffusivity, equilibrium solubility). These properties are temperature dependent, and lower temperatures generally favor absorption of gases by the solvent. Absorption is also enhanced by greater contacting surface, higher liquid-gas ratios, and higher concentrations in the gas stream (EPA, 1991). Chemical absorption may be limited by the rate of reaction, although the rate-limiting step is typically the physical absorption rate, not the chemical reaction rate (EPA, 1996). In addition, spent scrubbing waste water will be generated during unit operations and usually is not returned to the original system for recycle.

\section{Step 4: Evaluation of Most Effective Control Technologies}

To generate the data for the evaluation of the most effective control technologies for toxic organic compounds, an economic evaluation of the two highest ranked technologies with efficiencies of $99 \%$ or greater was performed. The economic evaluations, total capital and annual operating costs, for thermal non-catalytic oxidation and activated carbon adsorption are given in Table $4-4$ and $4-5$, respectively.

The economic analyses included evaluation of direct and indirect capital costs (equipment and installation), as well as annual operating costs (utilities, labor, and maintenance costs). To estimate the technology equipment costs, the equipment was sized based on the flow of each unabated off-gas stream. The equipment cost estimates were based on EPA guidance documents and vendor information. Next, factors for fabrication from corrosion resistant materials were applied. The above costs do not include disposal of secondary waste or post-oxidation acid gas treatment. 
The equipment costs used in this evaluation were obtained by NUCON International, Inc by obtaining quotes from suppliers (Appendix 1) and using previous experience and expertise in ammonia TBACT evaluations; and reviewing costs from letter 0401233/DOE-ORP: 04-ED057,"Submittal of Toxic Best Available Control Technology (tBACT) Determination and Revised Pages to Non-Radiological Notice of Construction for Operation of New Ventilation Systems In AN and AW Tank Farms (RPP-20774)"- Letter.

and 24590-WTP-RPT-ENV-01-005, Best Available Control Technology Analysis for Toxic Air Pollutants for the WTP (2002). Specific quote costs were given priority over the report estimated costs, which were 2002 and 2004 vintage, although in several cases where comparisons were made between estimates and quotes; the differences in cost were minor. The total annualized costs were based on a $10 \%$ rate of return and a 40 -year facility life for activated carbon adsorption with treated adsorbent and a 10-year facility life for thermal non-catalytic oxidation due to corrosion issues mainly from halogenated organic compounds.

\section{Step 5: Select tBACT}

The cost/ton for removal of toxic organic compounds exceeds the cost effective threshold previously acceptable to Ecology. Therefore, no specific control technologies were selected for toxic organic compounds removal. The annualized costs are summarized in Section 8. 


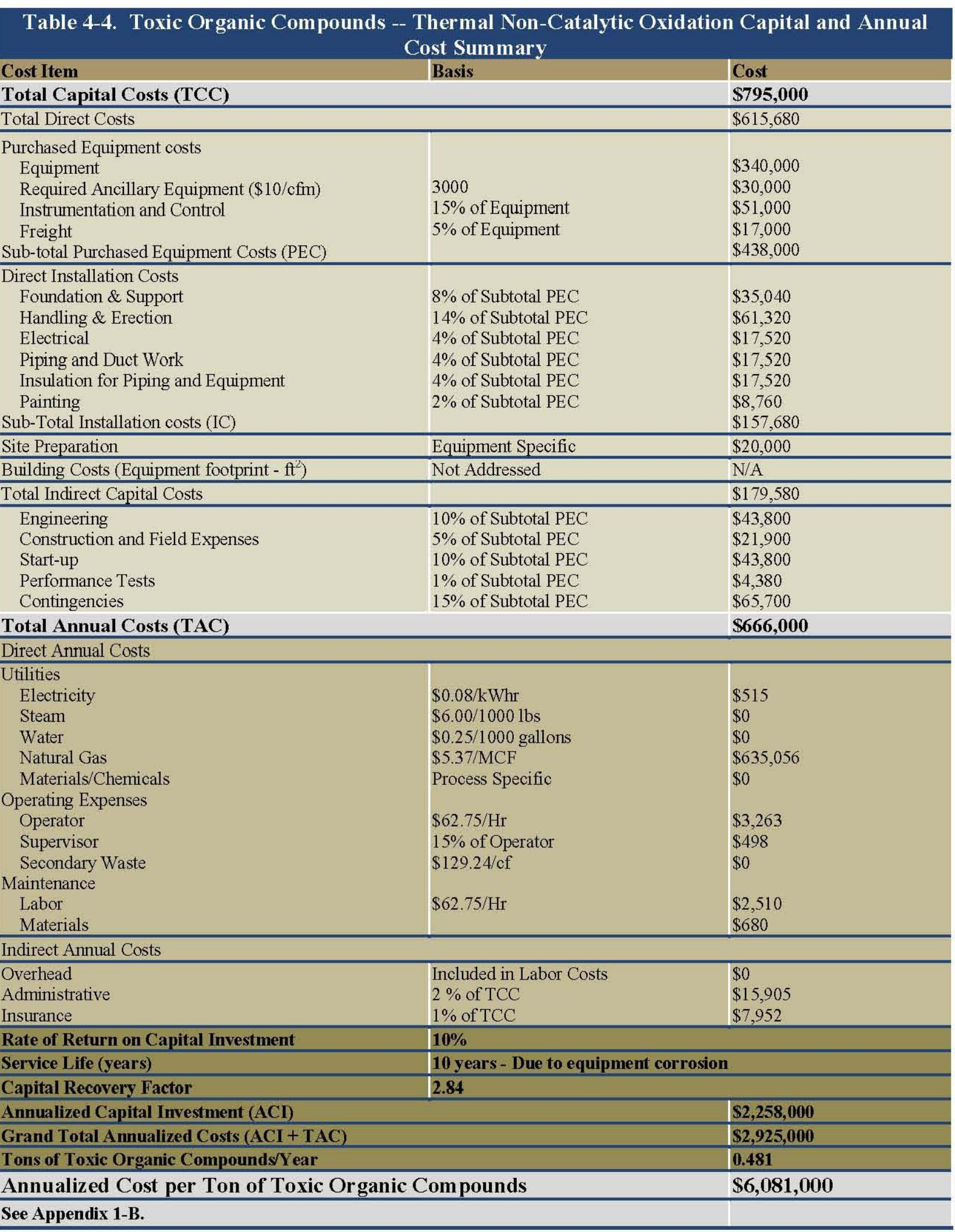




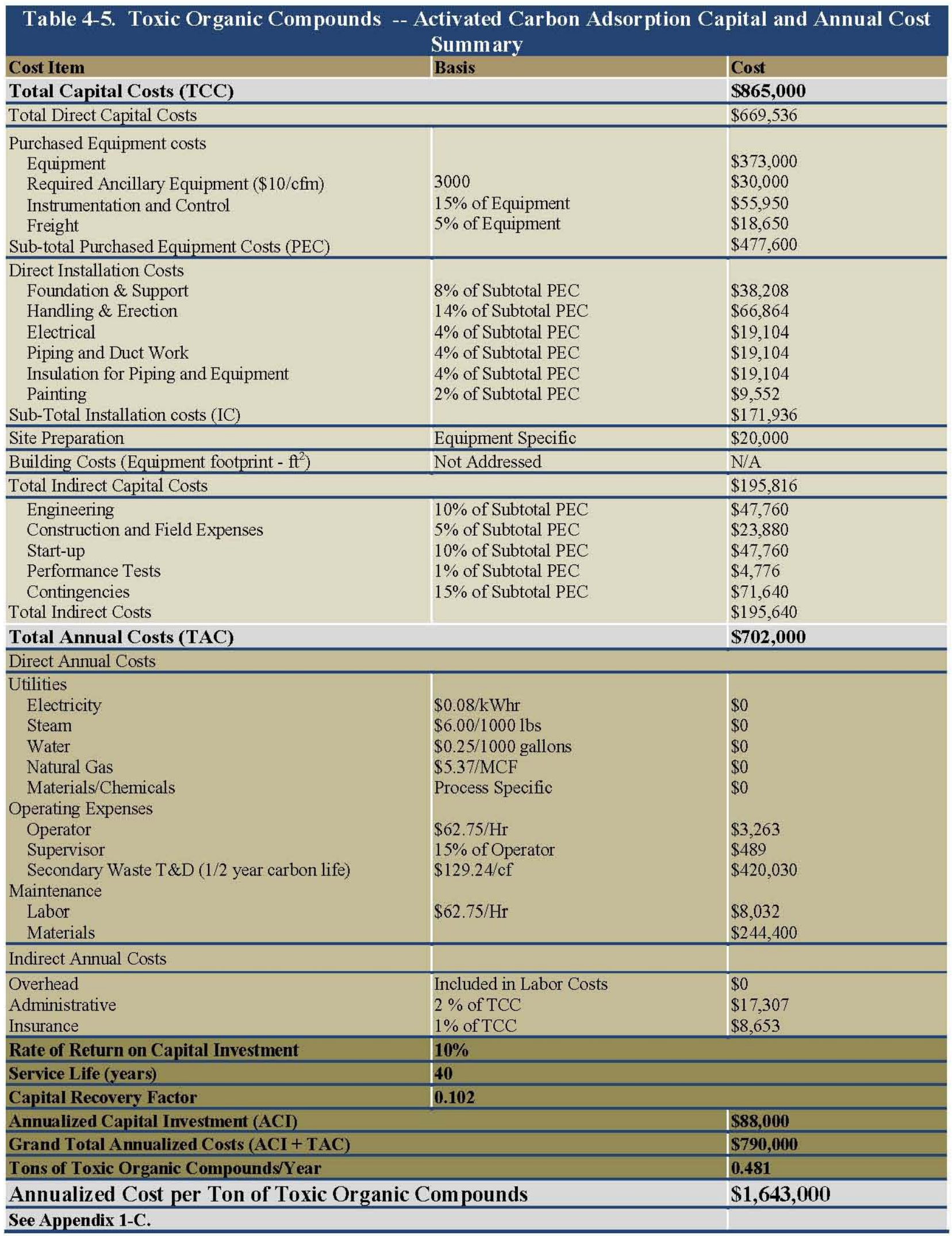


5.0 IdENTIFICATION AND EVALUATION OF EMISSION CONTROL TECHNOLOGY OPTIONS FOR AMmonia

This section covers the detailed evaluation for ammonia emissions tBACT. Ammonia emissions have been defined by RPP-RPT-44009 and SVF-1821. Emissions are estimated to be $72 \mathrm{lb} / 24 \mathrm{hr}$ averaging period derived from Table 3-1 or 13 tons/year.

\section{Step 1: Emission Control Technologies Identified}

EPA documents present add-on control technologies used for ammonia emissions control (Control and Pollution Prevention Options for Ammonia Emissions, EPA-456/R-95-002). The add-on control technologies identified are wet scrubbers and condensation. These technologies are thoroughly described in the EPA references (EPA-456/R-95-002 and EPA/452/B-02-001) and in letter 0401233/DOE-ORP: 04-ED-057. Use of the EPA cost estimating program also suggests two other technologies may be considered as control technologies including activated carbon adsorption and thermal oxidation. The following emission control technologies have been identified for the destruction and/or removal of ammonia:

- Wet scrubber absorption

- Activated carbon adsorption with untreated adsorbent

- Activated carbon adsorption with treated adsorbent

- Thermal non-catalytic oxidation

- Thermal catalytic oxidation

- Biofiltration

- Condensation

\section{Step 2: Elimination of Technically Infeasible Options}

Qualitative screening and elimination criteria were developed for the selective elimination of control technologies evaluated to be technically infeasible or not applicable for treatment of ammonia emissions from the primary ventilation system for DST farm operations. The screening criteria were applied for the suite of control technologies for ammonia removal and/or destruction listed above and are shown in Table 5-1. The identified emission control technologies that are technically infeasible and eliminated include:

- Activated carbon adsorption with untreated adsorbent

- Thermal catalytic oxidation

- Biofiltration

- Condensation

Activated Carbon Adsorption with Untreated Adsorbent: Activated carbon adsorption with untreated adsorbent is not suitable for the DST farm source term. This is due to low adsorption capacity/efficiency of most commercially available adsorbents and associated at the low ammonia concentrations that exist in the DST farm exhaust. See Section 4.0, Activated Carbon Adsorption discussion, for additional details. 


\begin{tabular}{c|l|c}
\hline \multicolumn{2}{c}{ Table 5-1. Ammonia - Potential tBACT } \\
Technology & Screening Results \\
\hline $\mathbf{1}$ & Wet Scrubber Absorption & Acceptable \\
\hline $\mathbf{2}$ & Activated Carbon Adsorption with Untreated adsorbent & Eliminated \\
\hline $\mathbf{3}$ & Activated Carbon Adsorption with Chemically Treated Adsorbent & Acceptable \\
\hline $\mathbf{4}$ & Thermal Non-Catalytic Oxidation & Acceptable \\
\hline $\mathbf{5}$ & Thermal Catalytic Oxidation & Eliminated \\
\hline $\mathbf{6}$ & Biofiltration & Eliminated \\
\hline $\mathbf{7}$ & Condensation & Eliminated
\end{tabular}

Thermal Catalytic Oxidation: Thermal catalytic oxidation can be used to reduce volatile organic compounds and ammonia emissions from a variety of sources. Generally high flow, low concentration applications are best suited to control these process units. Particulates or halogenated volatile organic compounds and heavy metals can clog the packed bed or poison or deactivate the catalyst reducing the design life of the unit. Specific poisons include halogenated compounds, mercury, arsenic, sulfur, sodium, and calcium. See Section 4.0, Thermal Catalytic Oxidation discussion, for further details.

Biofiltration: A bio-filter consists of a bed packed with biological material, sometimes even two or three beds. The gas stream is lead through the filter bed where the contaminants are removed from the waste gas by adsorption to and absorption by the filtering material. The components are then decomposed by micro-organisms. The bed consists of a carrier containing biological material such as: compost, tree bark, coconut fibers or peat. To decrease the amount of acidification, calcium or dolomite is sometimes added to the packing material. At high concentrations of nitrogenous, sulfurous or halogenated compounds, the forming of respectively nitric acid, sulfuric acid and hydrochloric acid may acidify the filtering material reducing the overall removal efficiency of the process, thus, drastically increasing the replacement frequency of the filtering material.

Condensation: Condensation technology removes pollutants from a gas stream that is saturated with water or warm and damp, by condensing to far below the water's dew point. The condensate that forms on the heat exchanger, serves as an absorption liquid for contaminants that are easily dissolvable in water. The relatively large contact surface that is required for the exchange of heat is also used as a contact surface for the exchange of dust. After passing through the condenser the gas stream is $100 \%$ saturated with water and the remaining condensate drips are collected with a demister, thus, the contaminants are captured and removed in the liquid phase. Due to the low concentration of ammonia and high moisture content of the DST farm emissions, the ventilation exhaust would have to be dried to lower dew points than the ammonia condensation temperature to prevent freezing and clogging of the condenser. 
Step 3: Rank Remaining Control Technologies by Control Effectiveness

The remaining applicable and available best control technologies for ammonia are shown in Table 5-2. All of these control technologies have a removal efficiency of $99 \%$ or greater and are ranked equally.

\section{Activated Carbon Adsorption with} Chemically Treated Adsorbent: For the removal of ammonia, the activated carbon needs to be chemically treated with phosphoric acid (between 15-30 wt\%) to obtain removal efficiencies of greater than $99 \%$. The activated carbon acts a collection substrate while the ammonia removal takes place by a reaction between the ammonia and the phosphoric acid. The ammonia removal capacity under equilibrium conditions is near stochiometric and is related to the phosphoric acid concentration. Adsorption efficiency is affected by other compounds that can be adsorbed on the activated carbon but will not be poisoned by them.

Removal efficiency is greater than $99 \%$ for fresh adsorbent and decreases near the stochiometric loading of the adsorbent. Adsorption on chemically treated activated carbon is more suitable for low concentrations of ammonia but it is capable of handling limited ammonia concentration spikes. Spent chemically treated adsorbent, while theoretically can be re-activated by thermal treatment, is typically disposed in landfills. See Section 4.0, Activated Carbon Adsorption discussion, for further details.

Thermal Non-Catalytic Oxidation: Thermal non-catalytic oxidation is a high temperature airammonia process reaction without the use of a catalyst. The destruction efficiency depends on the temperature of the unit operations. Greater than $99 \%$ ammonia destruction can be achieved at low temperature.

This technology is also capable of handling various concentrations of ammonia in the inlet stream and it is not sensitive to concentration spikes. In addition, thermal non-catalytic oxidation is not sensitive to halogenated or metallic compounds in the inlet stream (i.e., treats and destroys the majority of toxic or volatile organic compounds). However, acids and dioxins will be generated during the destruction of halogenated organic compounds, which will contribute an increased corrosion rate on materials of construction, thus, shortening the design life of the process unit. Oxides of nitrogen are also generated by this process, which depending on concentration may require additional treatment. See Section 4.0, Thermal Non-Catalytic Oxidation discussion, for further details.

Wet Scrubber Absorption: Scrubber absorption is a common emission technology for ammonia reduction, however it is used at higher concentrations than present in defined DST farm source term (RPP-RPT-44009 and SVF-1821). At defined source term concentrations, the scrubbing liquid has to be acidified to efficiently collect the ammonia. The scrubbing liquid is replenished based on the conversion rate to salt and needs to be treated as secondary waste. 
The spent scrubbing secondary waste water cannot be returned to the DST system and will need to be sent to the effluent treatment facility (ETF). The quantity of ammonium sulfate which would have to be treated by the ETF, based on the source term value, is in excess of 100 tons/year and exceeds the current ETF treatment capacity. See Section 4.0, Wet Scrubber Absorption discussion, for further details.

\section{Step 4: Evaluation of Most Effective Control Technologies}

To generate the data for the evaluation of the most effective control technologies for ammonia, an economic evaluation of the above identified technologies applied to each unabated off gas stream was performed. The economic evaluations for ammonia control technologies are shown in the following tables:

- Table 5-3 - Thermal non-catalytic oxidation

- Table 5-4 - Activated carbon adsorbers with treated adsorbent

- Table 5-5 - Wet scrubber absorption

The economic analyses included evaluation of direct and indirect capital costs (equipment, installation), as well as annual operating costs (utilities, labor, and maintenance costs). To estimate the technology equipment costs, the equipment was sized based on the flow of each unabated off gas stream. The equipment cost estimates were based on EPA guidance documents and vendor information. Factors for fabrication from corrosion resistant materials and adaptation to field operations and maintenance were applied. The above costs do not include disposal of secondary waste or post-oxidation acid gas treatment.

The equipment costs used in this evaluation were obtained by NUCON International, Inc by supporting the design and fabrication of similar facilities by obtaining quotes from suppliers (Appendix 1) and using previous experience and expertise in ammonia tBACT evaluations; and reviewing costs from letter 0401233/DOE-ORP: 04-ED-057. Specific quote costs were given priority over the report estimated costs, which were 2002 and 2004 vintage, although in several cases where comparisons were made between estimates and quotes the differences in cost were minor. The total annualized costs were based on a $10 \%$ rate of return and a 40 -year facility life for activated carbon adsorption with treated adsorbent and a 10-year facility life for thermal noncatalytic oxidation and wet scrubber absorption due to corrosion issues mainly from halogenated organic compounds and sulfuric acid scrubbing liquids, respectively.

\section{Step 5: Select tBACT}

The $\$$ /ton for removal of ammonia exceeds the cost effective threshold previously acceptable to Ecology. Therefore, no specific control technologies were selected for ammonia removal. The annualized costs are summarized in Section 8. 


\section{Table 5-3. Ammonia -- Thermal Non-Catalytic Oxidation Capital and Annual Cost Summary}

\section{Cost Item}

Basis

Total Capital Costs (TCC)

Cost

Total Direct Capital Costs

$\$ 795,000$

Purchased Equipment costs

$\$ 615,680$ Equipment

Required Ancillary Equipment (\$10/cfm)

Instrumentation and Control

Freight

Sub-total Purchased Equipment Costs (PEC)

Direct Installation Costs

Foundation \& Support

Handling \& Erection

Electrical

Piping and Duct Work

Insulation for Piping and Equipment

Painting

Sub-Total Installation costs (IC)

Site Preparation

)

$2 \%$

Building Costs (Equipment footprint - $\mathrm{ft}^{2}$ )

Total Indirect Capital Costs

Engineering

Construction and Field Expenses

Start-up

Performance Tests

Contingencies

Total Annual Costs (TAC)

Direct Annual Costs

Utilities

Electricity

Steam

Water

Natural Gas

Materials/Chemicals

Operating Expenses

Operator

Supervisor

Secondary Waste T\&D (1/2 year carbon life)

Maintenance

Labor

Materials

Equipment Specific

Indirect Annual Costs

Overhead

Administrative

Insurance

Rate of Return on Capital Investment

Service Life (years)

Capital Recovery Factor

Annualized Capital Investment (ACI)

Grand Total Annualized Costs (ACI + TAC)

Tons of Ammonia/Year

Annualized Cost per Ton of Ammonia

See Appendix 1-B.
3000

$15 \%$ of Equipment

$5 \%$ of Equipment

$8 \%$ of Subtotal PEC

$14 \%$ of Subtotal PEC

$4 \%$ of Subtotal PEC

$4 \%$ of Subtotal PEC

$4 \%$ of Subtotal PEC

$2 \%$ of Subtotal PEC

Not Addressed

$10 \%$ of Subtotal PEC

$5 \%$ of Subtotal PEC

$10 \%$ of Subtotal PEC

$1 \%$ of Subtotal PEC

$15 \%$ of Subtotal PEC

$\$ 340,000$

$\$ 30,000$

$\$ 51,000$

$\$ 17,000$

$\$ 438,000$

$\$ 35,040$

$\$ 61,320$

$\$ 17,520$

$\$ 17,520$

$\$ 17,520$

$\$ 8,760$

$\$ 157,680$

$\$ 20,000$

N/A

$\$ 179,580$

$\$ 43,800$

$\$ 21,900$

$\$ 43,800$

$\$ 4,380$

$\$ 65,700$

$\$ 666,000$

$\$ 515$

$\$ 0$

$\$ 0$

$\$ 635,056$

$\$ 0$

Process Specific

$\$ 3,263$

$\$ 62.75 / \mathrm{Hr}$

$15 \%$ of Operator

$\$ 129.24 / \mathrm{cf}$

$\$ 489$

$\$ 0$

$\$ 62.75 / \mathrm{Hr}$

$\$ 2,510$

$\$ 680$

Included in Labor Costs $\quad \$ 0$

$2 \%$ of TCC

$\$ 15,905$

$1 \%$ of TCC

$\$ 7,952$

$10 \%$

10 years - Due to equipment corrosion

2.84

$\$ 0.08 / \mathrm{kWhr}$

$\$ 0.25 / 1000$ gallons

(2.80




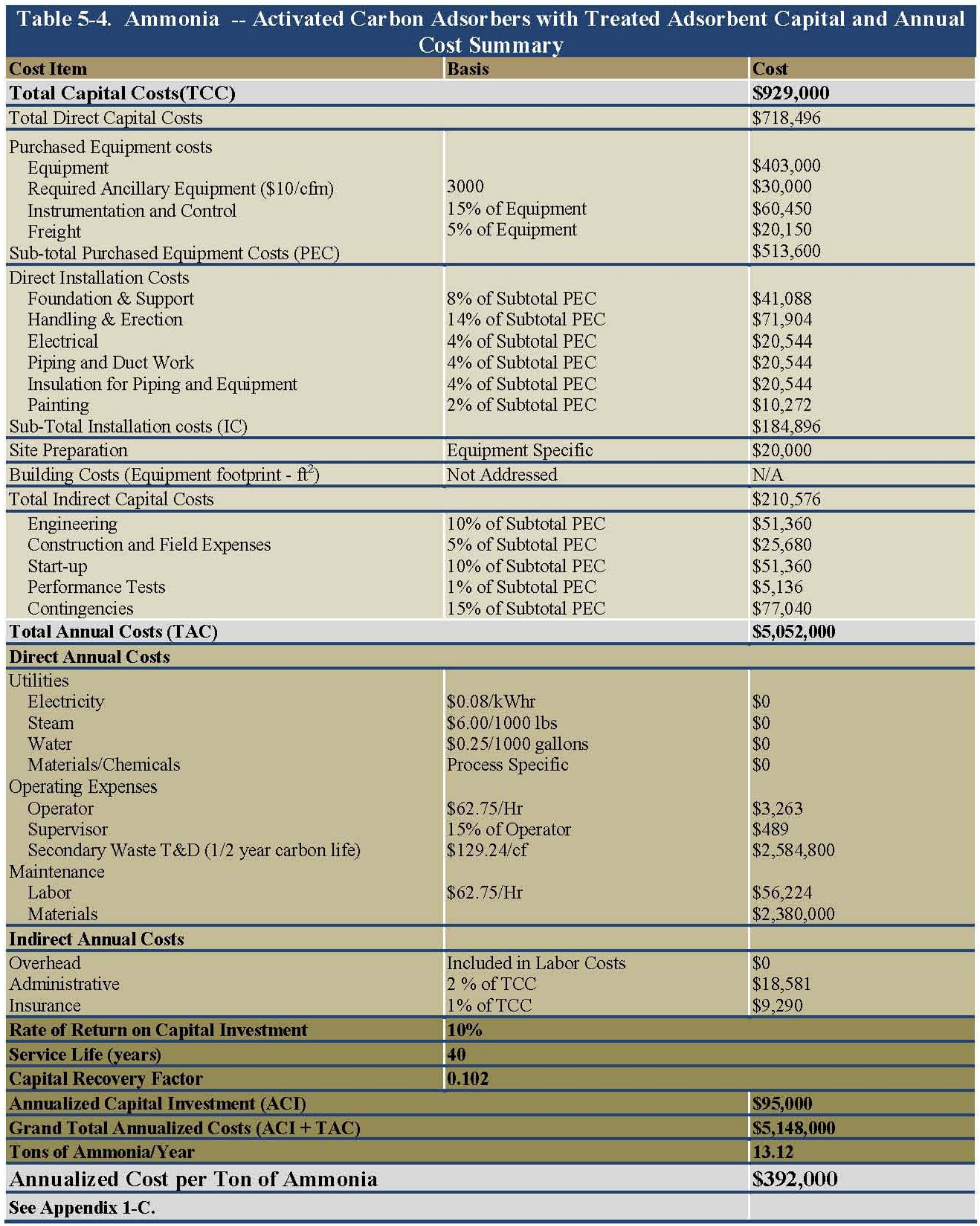




\begin{tabular}{|c|c|c|}
\hline Cost Item & Basis & Cost \\
\hline Total Capital Costs (TCC) & & $2,619,000$ \\
\hline Total Direct Capital Costs & & $\$ 2,017,568$ \\
\hline $\begin{array}{l}\text { Purchased Equipment costs } \\
\text { Equipment } \\
\text { Required Ancillary Equipment ( } \$ 10 / \mathrm{cfm}) \\
\text { Instrumentation and Control } \\
\text { Freight } \\
\text { Sub-total Purchased Equipment Costs (PEC) }\end{array}$ & $\begin{array}{l}3000 \\
15 \% \text { of Equipment } \\
5 \% \text { of Equipment }\end{array}$ & $\begin{array}{l}\$ 1,224,000 \\
\$ 0 \\
\$ 183,600 \\
\$ 61,200 \\
\$ 1,468,800 \\
\end{array}$ \\
\hline $\begin{array}{l}\text { Direct Installation Costs } \\
\text { Foundation \& Support } \\
\text { Handling \& Erection } \\
\text { Electrical } \\
\text { Piping and Duct Work } \\
\text { Insulation for Piping and Equipment } \\
\text { Painting } \\
\text { Sub-Total Installation costs (IC) } \\
\end{array}$ & $\begin{array}{l}8 \% \text { of Subtotal PEC } \\
14 \% \text { of Subtotal PEC } \\
4 \% \text { of Subtotal PEC } \\
4 \% \text { of Subtotal PEC } \\
4 \% \text { of Subtotal PEC } \\
2 \% \text { of Subtotal PEC }\end{array}$ & $\begin{array}{l}\$ 117,504 \\
\$ 205,632 \\
\$ 58,752 \\
\$ 58,732 \\
\$ 58,732 \\
\$ 29,376 \\
\$ 528,768\end{array}$ \\
\hline Site Preparation & Equipment Specific & $\$ 20,000$ \\
\hline Building Costs (Equipment footprint $-\mathrm{ft}^{2}$ ) & Not Addressed & N/A \\
\hline Total Indirect Capital Costs & & $\$ 602,208$ \\
\hline $\begin{array}{l}\text { Engineering } \\
\text { Construction and Field Expenses } \\
\text { Start-up } \\
\text { Performance Tests } \\
\text { Contingencies }\end{array}$ & $\begin{array}{l}10 \% \text { of Subtotal PEC } \\
5 \% \text { of Subtotal PEC } \\
10 \% \text { of Subtotal PEC } \\
1 \% \text { of Subtotal PEC } \\
15 \% \text { of Subtotal PEC }\end{array}$ & $\begin{array}{l}\$ 146,880 \\
\$ 73,440 \\
\$ 146,880 \\
\$ 14,688 \\
\$ 220,320\end{array}$ \\
\hline Total Annual Costs (TAC) & & $\$ 143,000$ \\
\hline \multicolumn{3}{|l|}{ Direct Annual Costs } \\
\hline $\begin{array}{l}\text { Utilities } \\
\text { Electricity } \\
\text { Steam } \\
\text { Water } \\
\text { Materials/Chemicals } \\
\text { Operating Expenses } \\
\text { Operator } \\
\text { Supervisor } \\
\text { Secondary Waste T\&D in excess of EFF capacity } \\
\text { (cannot be directly calculated but is very high) } \\
\text { Maintenance } \\
\text { Labor } \\
\text { Materials }\end{array}$ & $\begin{array}{l}\$ 0.08 / \mathrm{kWhr} \\
\$ 6.00 / 1000 \mathrm{lbs} \\
\$ 0.25 / 1000 \text { gallons } \\
\text { Process Specific } \\
\$ 62.75 / \mathrm{Hr} \\
15 \% \text { of Operator } \\
\$ 129.24 / \mathrm{cf} \\
\$ 62.75 / \mathrm{Hr}\end{array}$ & $\begin{array}{l}\$ 0 \\
\$ 0 \\
\$ 10,000 \\
\$ 50,000 \\
\$ 3,263 \\
\$ 489 \\
\$ 0 \\
\$ 753 \\
\$ 204\end{array}$ \\
\hline \multicolumn{3}{|l|}{ Indirect Annual Costs } \\
\hline $\begin{array}{l}\text { Overhead } \\
\text { Administrative } \\
\text { Insurance }\end{array}$ & $\begin{array}{l}\text { Included in Labor Costs } \\
2 \% \text { of TCC } \\
1 \% \text { of TCC }\end{array}$ & $\begin{array}{l}\$ 0 \\
\$ 52,395 \\
\$ 26,197 \\
\end{array}$ \\
\hline Rate of Return on Capital Investment & $10 \%$ & \\
\hline Service Life (years) & 10 years - Based on cor & a wet environment \\
\hline Capital Recovery Factor & 2.84 & \\
\hline Annualized Capital Investment (ACI) & & $\$ 7,439,000$ \\
\hline Grand Total Annualized Costs (ACI + TAC) & & $7,583,000$ \\
\hline Tons of Ammonia/Year & & 13.12 \\
\hline Annualized Cost per Ton of Ammonia & & $\$ 577,000$ \\
\hline See Appendix 1-D. & & \\
\hline
\end{tabular}


6.0 IdENTIFICATION AND EVALUATION OF EMISSION CONTROL TECHNOLOGY OPTIONS FOR MERCURY COMPOUNDS

This section covers the detailed tBACT evaluation for mercury and related compounds including dimethyl mercury for the DST farm system. Mercury and related compound emissions have been evaluated and defined by RPP-RPT-44009 and SVF-1821. Dimethyl mercury is the only compound identified exceeding its ASIL limit $\left(1.00 \mathrm{E}-99 \mu \mathrm{g} / \mathrm{m}^{3}\right)$. The maximum off-site concentration for dimethyl mercury is estimated to be $3.23 \mathrm{E}-8 \mu \mathrm{g} / \mathrm{m}^{3}$, with a corresponding release rate of 5.40E-7 tons/year (derived from Table 3-1).

\section{Step 1: Emission Control Technologies Identified for Mercury Compounds}

The following emission control technologies have been identified for mercury compounds including dimethyl mercury:

- Wet scrubber Absorption.

- Powdered Carbon Injection

- Powdered Carbon Injection with chemically treated carbon

- Fixed Carbon Beds

- Fixed Carbon Beds with chemically treated carbon

- Depleted Brine Scrubbing

- Selenium Filters

- Gold Amalgamation

\section{Step 2: Elimination of Technically Infeasible Options}

Qualitative screening and elimination criteria were developed for the selective elimination of control technologies evaluated to be technically infeasible or not applicable for treatment of mercury compounds, including dimethyl mercury, emissions from the primary ventilation system of the DST farm operations. The screening criteria for applicability were applied to the control technologies listed above and are shown in Table 6-1. All identified control technologies except for one has been eliminated for the removal of mercury compounds. The primary reason for elimination of these technologies is due to they have not been proven at a sufficient scale and irresolvable technical difficulties. A brief description of each of each control technology is given below:

\begin{tabular}{lll}
\multicolumn{2}{c}{ Table 6-1. } & Mercury Compounds - Potential tBACT \\
\hline Control & Technical Description & Screening Results \\
\hline $\mathbf{1}$ & Wet scrubber Absorption & Eliminated \\
\hline $\mathbf{2}$ & Powdered Carbon Injection & Eliminated \\
\hline $\mathbf{3}$ & Powdered Carbon Injection with chemically treated carbon & Eliminated \\
\hline $\mathbf{4}$ & Fixed Carbon Beds & Eliminated \\
\hline $\mathbf{5}$ & Fixed Carbon Beds with chem ically treated carbon & Applicable \\
\hline $\mathbf{6}$ & Depleted Brine Scrubbing & Eliminated \\
\hline $\mathbf{7}$ & Selenium Filters & Eliminated \\
\hline $\mathbf{8}$ & Gold Amalgamation & Eliminated \\
\hline
\end{tabular}


Wet Scrubber Absorption: Wet scrubbing, requires highly reactive sulfur containing additives in the scrubbing liquor and has reasonable efficiency for water soluble mercury compounds only. It has been applied on some coal fired power plants where the primary purpose of the scrubbing is acid gas removal. There is no chemical reason or any experimental data indication to expect that organic mercury compounds can be removed. For example, dimethyl mercury, an organic mercury compound, is not water soluble and is not applicable for wet scrubbing abatement technologies. Extensive waste liquid disposal or collection and treatment are required to support this technology. See Section 5.0, Wet Scrubber Absorption discussion, for further details.

Powdered Carbon Injection: Powdered carbon injection is an existing control technology for power plants where powdered carbon is injected into the flue gas and reacts with mercury both in the gas phase and upon deposition in the particulate collecting bag-house of the power plant. It can be considered only when bag-house collectors are installed downstream and the carbon is continually injected and removed in conjunction with the ash collected in the bag-house. Mercury removal efficiencies have been cited between $50-70 \%$ for elemental mercury.

Powdered Carbon Injection with Treated Carbon: Powdered Carbon Injection with chemically treated carbon, is a variation of the above process, resulting in somewhat higher mercury removal efficiency at an increased carbon cost and commensurate corrosion problems from the typical additive bromine.

Fixed Carbon Beds with Untreated Carbon: Fixed carbon beds are used in several applications for mercury vapor control, but their use has been almost completely superseded by the use of chemically treated carbon in the fixed beds. The mercury is only physically adsorbed on untreated activated carbon and migrates through the adsorbent bed according to the mass transfer conditions in the fixed bed. Untreated carbon is more sensitive to the presence toxic organic compounds and inorganic vapors than the treated carbons. (EPA-452-R-R7-010, Mercury Study Report to Congress, Volume VIII: An Evaluation of Mercury Control Technologies and Costs, December 1997 and EG\&G-2008-EERC-01-02, EG\&G Carbon Evaluation for Mercury Removal)

Depleted Brine Scrubbing: Depleted brine scrubbing is applicable only to chlor-alkali plants where the brine is one of the flow streams. This technology is not applicable and is not used in the other applications.

Selenium Filters: Selenium on adsorbent based filters was eliminated due to selenium being a toxic material. Sulfur on adsorbents is equally reactive without the additional toxic hazards and is lower in cost.

Gold Amalgamation: Gold amalgamation is not an industrial process and has only been applied in mercury concentration measuring instruments only. There is no commercial or industrial destruction or removal application for this process Sjostrom, et.al, EPA, "Development and Demonstration of Mercury Control by Adsorption Processes (MerCAP ${ }^{\mathrm{TM} 1}$ )."

${ }^{1} \mathrm{MerCAP}^{\mathrm{TM}}$ is a Trademark of Lesman Instrument Company, Bernice, Illonois 


\section{Step 3: Rank Remaining Control Technologies by Control Effectiveness}

Effectiveness is defined by the ability of the control technology to reduce the post treatment emission rate for dimethyl mercury. The only control technology found to be applicable for mercury (including dimethyl mercury) control is fixed carbon beds with chemically treated activated carbon.

Carbon, that is chemically treated with sulfur or iodine, can remove mercury compounds. The most common in industrial applications is the sulfur impregnation of the carbon and is used in similar composition and size off gas control in the U.S. (e.g., chemical weapons incineration off gas mercury control, mixed waste incinerator off gas control, nuclear waste melter off gas control, petrochemical processing). In these applications, the impregnated activated carbon (IAC) is placed in a fixed bed, either vertically or horizontally and used until the exhaustion of the IAC. The life of the IAC is dependent on total mercury inlet concentration.

Several laboratory, pilot and full scale tests have been performed with varying degrees of inlet mercury concentrations in air, in natural gas, and with organic compounds present in the offgases of melters, incinerators and other gaseous waste treatment facilities. [INEEL/CON-9701225 1997, Mercury Emissions Control Technologies for Mixed Waste Thermal Treatment (1997); INEEL/CON-00-01332 2001, Removal of Mercury from the Off-Gas from Thermal Treatment of Radioactive Liquid Wastes (2001)]. One of the common IACs is MERSORB® ${ }^{2}$ for which additional test reports are also attached. (Appendix 2)

Impregnated Activated Carbon mercury vapor abatement technologies are mature and have been successfully used for the control of effluents and emissions in both nuclear and military applications. The nuclear application typically treats radioactive waste melter effluents and incineration off gases from processes such as the THOR ${ }^{\circledR}$ Process ${ }^{3}$ [Soelberg, et al, IT3 2007 Conference, Off-Gas Mercury control using Sulfur Impregnated Activated Carbon - Test Results, (May 2007)]. The military applications consist primarily of the effluent control from chemical agent destruction either by thermal or chemical processes.

Several of the tests reported in the MERSORB® Bulletin were performed using radioactive mercury $\left({ }^{159} \mathrm{Hg}\right)$. Comparing the total mercury decontamination results between the air gas carrier and natural gas carrier gas streams indicates that the total mercury removal was better from the natural gas stream, where organic mercury could form from the air stream. The manner, in which the tests were run, would have indicated different movement of mercury species by dual radioactivity peaks. No movement of mercury species were observed for long-term test data generated under chemical agent incineration condition air flows and operations.

There are also reports showing that dimethyl mercury in the presence of methanol decomposes to methane and elemental mercury [Wongkasemjit, Laboratory Study of Corrosion Effect of Dimethyl Mercury on Natural Gas Processing Equipment (2000)]. Considering that the methanol flux in the gas stream is about six orders of magnitude higher than the dimethyl mercury flux, it is expected that during adsorption treatment of both compounds through the IAC bed, it would give sufficient contact time to decouple the mercury from the methyl group.

In addition, the Washington State Department of Ecology evaluated mercury and dimethyl mercury releases from several landfills. [Prestbo, Determination of Total and Dimethyl Mercury

\footnotetext{
${ }^{2}$ MERSORB is a registered trademark of Nucon International, Columbus, $\mathrm{OH}$

${ }^{3}$ THOR is a trademark of THOR Treatment Technologies, Richland, WA
} 
in Raw Landfill Gad with Site Screening for Elemental Mercury at Eight Washington State Landfills for the Washington State Department of Ecology )July 2003)] The sampling train which used an untreated carbon substrate without impregnation, preferentially adsorbed dimethyl mercury to elemental mercury.

Under the current Ecology regulations, evaluation of dimethyl mercury abatement systems is triggered at levels over 1.00E-99.

The landfill study, cited above, used the best available detection method and resulted in a dimethyl mercury analysis above $20 \mathrm{ng} / \mathrm{m} 3$. This resulted in a reasonable relative standard deviation (RSD) of $\sim 10 \%$. Below $2 \mathrm{ng} / \mathrm{m} 3$ the RSD increased to above $80 \%$. Based on this report, in a similar gas stream matrix, the minimum reliable detection limit for dimethyl mercury is $10 \mathrm{ng} / \mathrm{m} 3$ or $110 \mathrm{E}-2 \mu \mathrm{g} / \mathrm{m}^{3}$.

\section{Step 4: Evaluation of Most Effective Control Technologies}

On the basis of the above, the only available, proven technology for total mercury control, even in the presence of dimethyl mercury, is treatment of the gas stream by IAC. The sizing, costing and operating costs are based on one of the IACs MERSORB®. The economic evaluations, total capital and annual costs, are shown in Table 6-2.

The economic analyses included evaluation of direct and indirect capital costs (e.g., equipment, installation), as well as annual operating costs (e.g., utilities, labor, and maintenance costs). To estimate the technology equipment costs, the equipment was sized based on the flow of each unabated off-gas stream. The equipment cost estimates were based on EPA guidance documents and vendor information. Next, factors for fabrication from corrosion resistant materials and adaptation to radioactive environment operations and maintenance were applied. The above costs do not include disposal of secondary waste or post-oxidation acid gas treatment.

The equipment costs used in this evaluation were obtained by NUCON International, Inc. who owns MERSORB® technology. The total annualized costs were based on a $10 \%$ rate of return and a 40 -year facility life and a $10 \%$ rate of return on capital for mercury compounds including dimethyl mercury emissions control.

\section{Step 5: Select tBACT}

The cost/ton for removal of mercury and mercury related compounds exceeds the cost effective threshold previously acceptable to Ecology. Therefore, no specific control technologies were selected for mercury and mercury related compounds removal. The annualized costs are summarized in Section 8. 
Table 6-2. Mercury and Mercury Related Compounds - Fixed Carbon Beds with Chemically Treated Adsorbent tBACT Control Technology - Capital and Annual Cost Summary

Cost Item Basis

Cost

Total Capital Costs (TCC)

$\$ 598,000$

Total Direct Capital Costs

$\$ 463,904$

Purchased Equipment costs Equipment

Required Ancillary Equipment (\$10/cfm)

Instrumentation and Control

Freight

Sub-total Purchased Equipment Costs (PEC)

$\$ 247,000$

3000

$\$ 30,000$

$15 \%$ of Equipment $\$ 37,050$

$5 \%$ of Equipment $\$ \$ 12,350$

Direct Installation Costs

Foundation \& Support

Handling \& Erection

Electrical

Piping and Duct Work

Insulation for Piping and Equipment

Painting

Sub-Total Installation costs (IC)

Site Preparation

C)

Building Costs (Equipment footprint $-\mathrm{ft}^{2}$ )

Total Indirect Capital Costs

Engineering

Construction and Field Expenses

Start-up

Performance Tests

Contingencies

$\$ 326,400$

Total Annual Costs (TAC)

$8 \%$ of Subtotal PEC

$14 \%$ of Subtotal PEC

$4 \%$ of Subtotal PEC

$4 \%$ of Subtotal PEC

$4 \%$ of Subtotal PEC

$2 \%$ of Subtotal PEC

Equipment Specific

Not Addressed

$10 \%$ of Subtotal PEC

$5 \%$ of Subtotal PEC

$10 \%$ of Subtotal PEC

$1 \%$ of Subtotal PEC

$15 \%$ of Subtotal PEC

Total Annual Direct Costs

Utilities

Electricity

Steam

Water

Materials/Chemicals

Operating Expenses

Operator

Supervisor

Secondary Waste T\&D ( $1 / 2$ year carbon life)

Maintenance

Labor

Materials

Total Annual Indirect Costs

Overhead

Administrative

Insurance

Rate of Return on Capital Investment

Service Life (years)

Capital Recovery Factor

Annualized Capital Investment (ACI)

Grand Total Annualized Costs (ACI + TAC)

Tons of Mercury Compounds/Year

Annualized Cost per Ton of Mercury and Mercury Related Compounds

\section{$\$ 0.08 / \mathrm{kWhr}$}

$\$ 6.00 / 1000 \mathrm{lbs}$

$\$ 0.25 / 1000$ gallons

Process Specific

$\$ 62.75 / \mathrm{Hr}$

$15 \%$ of Operator

$\$ 129.24 / \mathrm{cf}$

$\$ 62.75 / \mathrm{Hr}$

Included in Labor Costs

$2 \%$ of TCC

$1 \%$ of TCC

$10 \%$

40

0.102
$\$ 26,112$

$\$ 45,696$

$\$ 13,056$

$\$ 13,056$

$\$ 13,056$

$\$ 6,528$

$\$ 117,504$

20,000

N/A

$\$ 133,824$

$\$ 32,640$

$\$ 16,320$

$\$ 32,640$

$\$ 3,264$

$\$ 48,960$

$\$ 33,000$

$\$ 0$
$\$ 0$
$\$ 0$
$\$ 0$
$\$ 3,263$
$\$ 489$
$\$ 4,061$
$\$ 401$
$\$ 4,675$

o

$\$ 11,954$

$\$ 5,977$

See Appendix 1-C. 
7.0 IdENTIFICATION AND EVALUATION OF EMISSION CONTROL TECHNOLOGY OPTIONS FOR Particulate Metal Compounds

This section covers the detailed tBACT evaluation for non-mercury metal compounds for the DST farm system. Several of the non-mercury metal compounds have emissions above the de minimis levels. RPP-RPT-44009 and SVF-1821 and are summarized in Table 7-1. These compounds will be present in particulate form as metals or metal salts.

\begin{tabular}{l|l}
\hline \multicolumn{2}{c|}{ Table 7-1. Particulate Concentrations } \\
Particulate & Concentration $\left(\boldsymbol{\mu g} / \mathbf{m}^{\mathbf{3}}\right)$ \\
\hline Arsenic (particulate form only; excludes hydrides) & $1.69 \mathrm{E}-06$ \\
\hline Beryllium & $8.46 \mathrm{E}-08$ \\
\hline Cadmium & $8.46 \mathrm{E}-07$ \\
\hline Chromium & $2.59 \mathrm{E}-06$ \\
\hline Cobalt & $5.14 \mathrm{E}-05$ \\
\hline Manganese & $5.14 \mathrm{E}-05$ \\
\hline
\end{tabular}

WAC 173-480-060, Emission Standards for New and Modified Emission Units and WAC 246247-040, Radiation Protection - Air Emissions state that a BARCT for radionuclides (particulates) is required and that, at a minimum, a filter train consisting of prefilters, mist eliminators, and dual HEPA filters must be employed. Since these technologies have already been evaluated for radionuclides, they will control emissions of particulate metal compounds identified in Table 7-1. No further technology selection or evaluation steps were performed except for the evaluation of the radiological control required filtering components efficiency for these pollutants.

The individual technology components in-place stage efficiencies of exhaust trains required by WAC 173-480-060 are: Mist Eliminator - 99\%, Prefilter - 80\%, and HEPA Filtration each stage $99.95 \%$. This combination results in higher than $99.99 \%$ combined removal efficiency, but a conservative removal efficiency value of $99.99 \%$ is used. The efficiencies listed for HEPA filters are based on the 0.1-0.3 micrometer size, least filterable, particle size range. The efficiency for this type of HEPA filter is higher for both smaller and larger particle sizes.

The combination of the above listed particulate metal compounds control technologies achieve a combined removal efficiency of $99.99 \%$ (in-place), when assembled according to ASME/ANSI N-509 Standard and have components that meet ASME AG-1 Code: Section FA (mist eliminators), Section FB (pre-filters), and Section FC (HEPA filters). This combination of air cleaning control technology components is currently required for primary ventilation of DST farms. Therefore, no further $\mathrm{tBACT}$ evaluations are required for particulate metal compounds. This set of control technologies are credited by a decontamination factor (DF) of 10,000 for the above listed particulate metal compounds TAPs, which brings all of these untreated TAP concentrations to the following treated values.

Justification of the $\mathbf{9 9 . 9 9 \%}$ mass based removal of metal aerosols: The existing and proposed DST farm Air Cleaning Unit (ACU) consists of particle removal components: demister (mist agglomerator); prefilter; HEPA filter 1; and HEPA filter 2. 
These elements remove various size aerosols at the currently accepted efficiency of:

- Demister $\rightarrow 99 \%$ liquid droplets by mass minimum and 99\% minimum for 5-10 micron range

- Pre-Filter $\rightarrow \sim 30-80 \%$ Atmospheric dust depending on type

- $1^{\text {st }}$ HEPA Filter $\rightarrow 99.97 \%$ Hot DOP minimum at 0.3 micron (AMAD size)

- $2^{\text {nd }}$ HEPA Filter $\rightarrow 99.97 \%$ Hot DOP minimum at 0.3 micron (AMAD size)

The above listed efficiencies are all based on single component efficiencies. The same efficiencies may not be true when applied to a system containing multiple components. Components that are installed in a "filter train" may have installation irregularities, in-place testing occurs using heterogeneous aerosol particles with a median diameter of 0.7 microns, and thus, each single bank installed HEPA filter leak tightness has to be a minimum of $99.95 \%$. These qualifications and in place tests are not "mass based" with the exception of mist eliminator which has a required mass basis a minimum of $99 \%$ efficiency.

The HEPA filters are qualification tested with 0.3 micron liquid aerosol droplets (DOP, Polyolefin, etc). The particle removal efficiency of the HEPA filters is higher for both larger and smaller aerosol sizes as shown on Figure 7-1. (Vendel 2009, NEA/CSNI/R 2009). The typical metal and metal oxide aerosols are heterogeneous in distribution and typically larger than the minimum efficiency filterable 0.3 micron. (Bowling 1941, Lujaniene 1995, Ogordkinov 2004, Papastefanos 2009). The removal efficiency for multiple banks HEPA filters while difficult to determine using the conventional DOP aerosol test method (due to inadequate test aerosol after the first stage) has been determined using radioactive aerosols. For example, a 0.22-0.66 micron ${ }^{238} \mathrm{PuO} 2$ aerosol resulted in a DF of $1.88 \mathrm{E} 12$ to $1.7 \mathrm{E} 13$ and for three HEPA filters in series the DF was from 2.1E12 to 4.7E13 [(Gonzales, Performance of Multiple HEPA Filters against Plutonium Aerosols (1974); Linck, In-Place Testing of Multiple Stage HEPA Filter Plenums (1974)]

In this evaluation, the decontamination credit of $99.99 \%$ by mass (DF of 10E4) for the metal aerosol compounds is assigned to the combination of a moisture separator, a prefilter and two HEPA filters in series when built according to the ASME AG-1 Code and in place tested according to ASME/ANSI N-510 (i.e. each HEPA stage in place tested individually). This combined mass removal efficiency can be achieved solely by the combined filtration efficiency of the above listed air cleaning elements without including the additional removal of the water droplet scrubbing of these aerosols on the mist eliminator. 


\section{Figure 7-1. Filter Penetration Versus Particle Size}

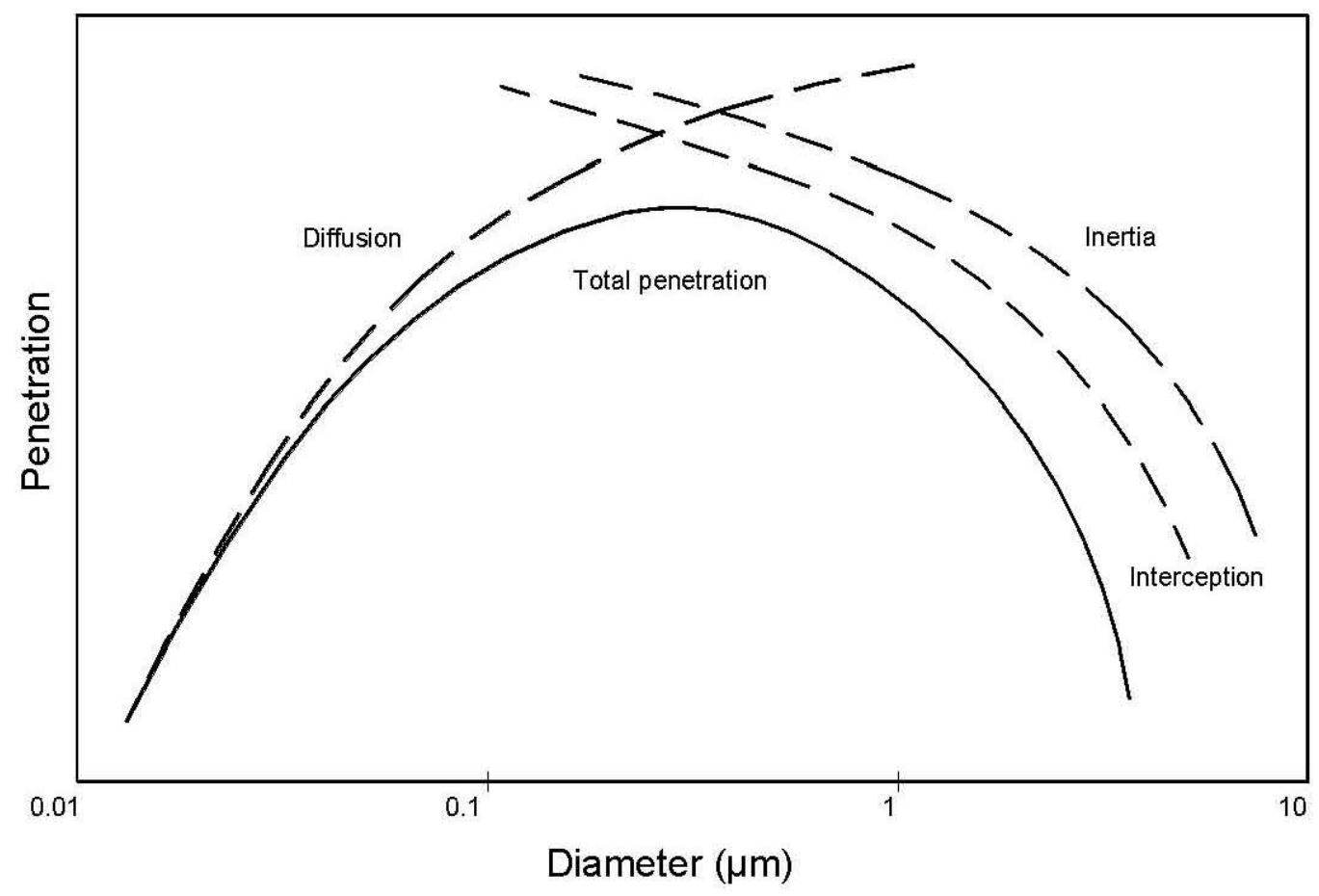




\subsection{TBACT RECOMMENDATION}

After detailed evaluation of the four TAPs and/or groups of TAPs and the effectiveness and costs of emission control technologies for each, a \$/ton was determined to implement a control technology as identified in Table 8-1. All of the identified technologies were eliminated because their cost per ton exceeded the cost ceiling guidelines previously approved by Ecology and EPA as economically unjustifiable. Although the evaluated technology would remove $98-99 \%$ of the pollutants, the cost of the abatement becomes prohibitive on a per ton basis due to the low emission rates.

Based on the results of this $\mathrm{tBACT}$ evaluation, the proposed $\mathrm{tBACT}$ control technology for the DST primary ventilation systems consists of a moisture de-entrainer, pre-heater, pre-filters, and a HEPA filtration system in the treatment train.

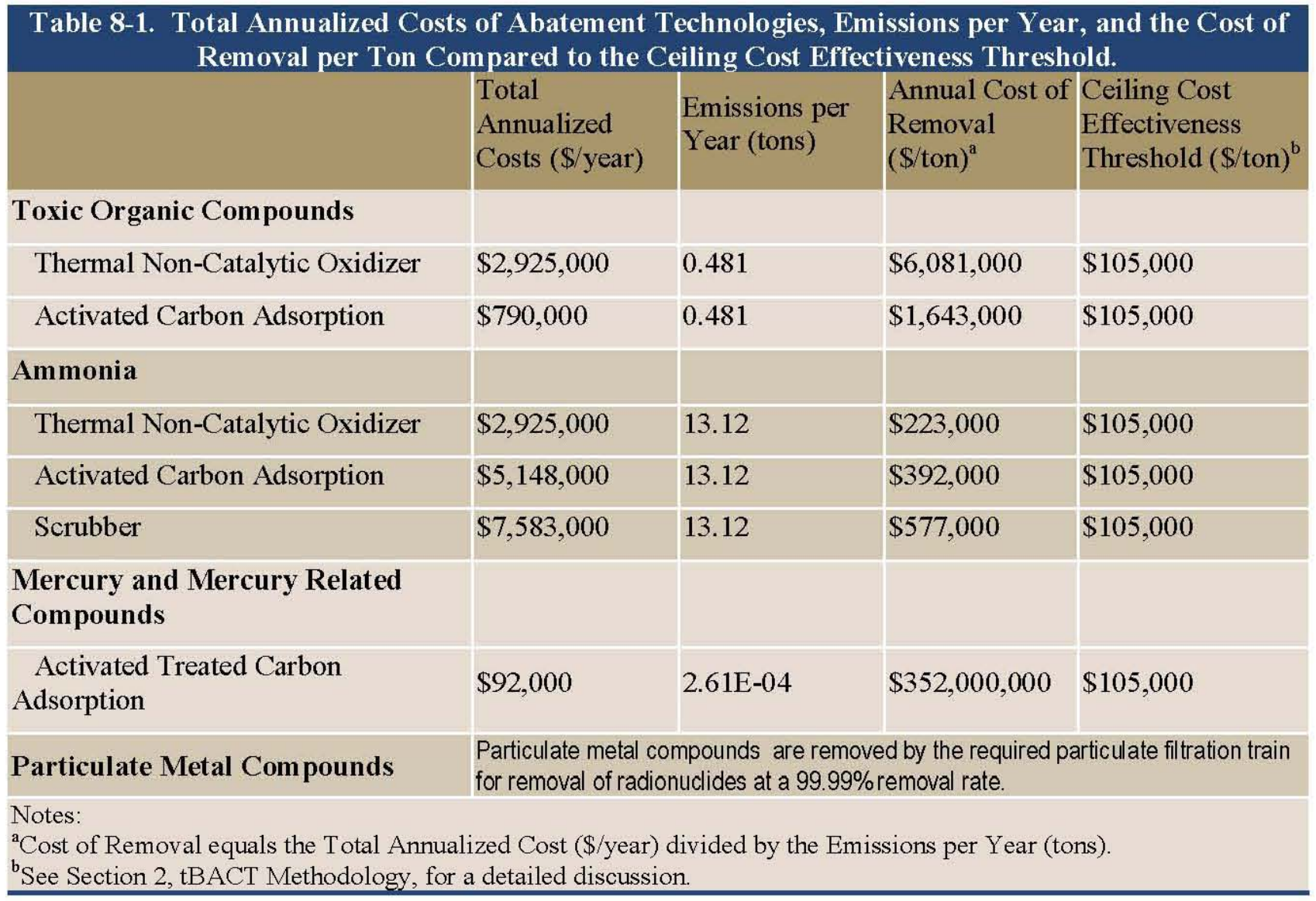




\subsection{REFERENCES}

ASME/ANSI N-509 Standard

ASME-AG-1-2009; Code on Nuclear Air and Gas Treatment; (September 30, 2009)

Bowling, R et al. No title, Ind. Eng. Chemical News, Vol.19, p. 965 (1941)

Croll Reynolds, Croll Reynolds Company, Inc., web site http://www.croll.com (Accessed March 2010)

EG\&G-2008-EERC-01-02; "EG\&G Carbon Evaluation for Mercury Removal" (Final Report), Stanley J. Miller, G.E. Dunham, L. V. Heebink \& E. s. Olsen (January 2008)

Eichholz, Richard, 11th International Chemical Weapons Demilitarization conference and Exhibition, "Investigation of Sulfur-Impregnated Carbon for Mercury Abatement in Chemical Weapons Incinerators" (May 2009)

EPA, Air Pollution Engineering Manual, Second Edition. U.S. Environmental Protection Agency, Research Triangle Park, North Carolina (1973)

EPA, New Source Review Workshop Manual, Prevention of Significant Deterioration (Containment Area Permitting, Washington, D.C., USA (1990)

EPA, Office of Research and Development, "Control Technologies for Hazardous Air Pollutants," EPA/625/6-91/014, Washington, D.C. (June, 1991)

EPA, Office of Air Quality Planning and Standards, "Control Techniques for Volatile Organic Emissions from Stationary Sources," EPA-453/R-92-018, Research Triangle Park, NC. (December, 1992)

EPA, Control and Pollution Prevention Options for ammonia emission' Control Technology Center, EPA-456-R-95-002 (April 1995)

EPA 453/B-96-001, Office of Air Quality Planning and Standards, "OAQPS Control Cost Manual," Fifth Edition, EPA 453/B-96-001, Research Triangle Park, NC (February, 1996)

EPA-452-R-R7-010, Mercury Study Report to Congress, Volume VIII: An Evaluation of Mercury Control Technologies and Costs, (December 1997)

EPA, Office of Air Quality Planning and Standards, "Stationary Source Control Techniques Document for Fine Particulate Matter," EPA-452/R-97-001, Research Triangle Park, NC (October, 1998)

EPA, Spray Tower Scrubber, EPA-CICA Pollution Technology Fact Sheet. EPA Internet Site, http://www.epa.gov/ttn/catc/products.html (2000).

EPA, Thermal Incinerator, EPA-CICA Pollution Technology Fact Sheet. EPA Internet Site http://www .epa.gov/ttn/catc/products.html (2001)

EPA, Air Pollution Control Cost Manual, Sixth Edition, EPA-452-B-02-001 (January 2002)

EPA 1995, Control and Pollution Prevention Options for ammonia emission 
EPA-452-B-02-001, Office of Air Quality Planning and Standards Air Pollution Control Cost Manual, Sixth Edition (2002)

Gonzales, M, et al "Performance of Multiple HEPA Filters against Plutonium Aerosols," $13^{\text {Th }}$ AEC Air Cleaning Conf., p501 (1974)

ICAC 1999, Institute of Clean Air Companies, Control Technology Information - Thermal Oxidation,

Letter February 18, 2005, M.A. Wilson to R.J. Schepens, Approval of Non-Radioactive Air emissions Notice of Construction (NOC) for Operation of New Ventilation Systems in AN and AW Tank Farms, Approval Order DE05NWP-001.

Letter October 12, 2005, M.A. Wilson to R.J. Schepens, Approval of Criteria and Toxic Emissions Notice of Construction (NOC) Application for Operations of Waste Retrieval Systems in Single-Shell Tank (SST) Farms as Supplemented with C Farm Exhauster Operation Incorporating C-200 Series Tanks and Aggregated Exhaust Points for the 241C Tank Farm, Approval Order DE05NWP-002, Rev. 1.

Letter July 31, 2007, J.A. Hedges to S Olinger, Approval of Criteria and Toxic Emissions Notice of Construction (NOC) Application, Hanford Single-Shell Tank Waste Retrieval, Approval Order DE05NWP-002 Rev. 2.

Letter July 8, 2004, R.J. Schepens to M.A. Wilson, Submittal of Toxic Best Available Control Technology (tBACT) Determination and Revised Pages to Non-Radiological Notice of Construction for Operation of New Ventilation Systems In AN and AW Tank Farms (RPP-20774), letter 0401233/DOE-ORP: 04-ED-057.

Linck, F.J. and Geer, J.A. "In-Place Testing of Multiple Stage HEPA Filter Plenums. $13^{\text {th }}$ AEC Air Cleaning Conf., p526 (1974)

Lujaniene, G et al. "An Investigation of Changes in Radionuclide Carrier Properties," J Environ. Radioactivity, Vol. 35 No 1 pp 71-90 (1996)

MERSORB® Mercury Adsorbents NUCON Bulletin 11B28 (August 2004)

National Research Council, "Carbon Filtration for Reducing Emissions from Chemical Agent Incineration", Committee on Review and evaluation of the Army Chemical Stockpile Disposal Program, Board on Army Science and Technology, Committee on Engineering and Technical Systems, National Research Council; (National Academy Press) (1999)

Prestbo, et.al., Frontier Geosciences, Inc, "Determination of Total and Dimethyl Mercury in Raw Landfill Gad with Site Screening for Elemental Mercury at Eight Washington State Landfills for the Washington State Department of Ecology," (July 2003)

RPP-RPT-44009 Rev 1, Spreadsheet Description Document for Non-Radiological Air Source Term for 241-SY Farm and 241-AP Farm Primary Ventilation System Upgrades, (May 2010)

Schweitzer, et.al., "Handbook of Separation Techniques for Chemical Engineers, 2 nd Edition; Section 3.1, "Gas Phase Adsorption,". (1988) 
Sjostrom, et.al., "Development and Demonstration of Mercury Control by Adsorption Processes $\left(\operatorname{MerCAP}^{\mathrm{TM}}\right), "(2001)$.

Soelberg, et.al, "IT3'07 Conference "Off-Gas Mercury Control Using Sulfur-Impregnated Activated Carbon-Test Results," (THOR Treatment Technologies, LLC," (May 2007)

SVF-1821, Rev 1, Non-Radiological Air Source Term for 241-SY Farm and 241-AP Farm Primary Ventilation System (May 2010)

WRPS, 2009a, Tank Waste Farms Information System (TWINS), Queried 12/28/2009, [Data,Data source selection forms, Measurements, SACS, Surface Level, AN107, Auto ENRAF, Surface level= 395.9 inches], Internet at http://wins.pnl.gov/twins.htm, Washington River Protection Solutions, LLC, Richland, Washington.

WRPS, 2009b, Tank Waste Farms Information System (TWINS), Queried 12/28/2009, [TWINS DataBase, Data, Data Source Selection Forms, Best Basis Calculation Detail, Tank 241AN-107, All analytes], Internet at http://twins.pnl.gov/twins.htm, Washington River Protection Solutions, LLC, Richland, Washington.

Vendel, j. et al. "Lessons learnt over 30 years of air filtration in the nuclear industry. Journal of Physics: Conf Series," 17001206 (2009)

WAC 246-247, "Radiation Protection - Air Emissions," Washington Administrative Code, as amended.

WAC 173-303, "Dangerous Waste Regulations," Washington Administrative Code, as amended.

WAC 173-400, "General Regulations for Air Pollution Sources," Washington Administrative Code, as amended.

WAC 173-460-150, "Controls for New Sources of Toxic Air Pollutants," Washington Administrative Code, as amended

WAC 173-480-060, "Emission Standards for New and Modified Emission Units," Washington Administrative Code, as amended

WAC 173-460-020, "Definitions," Washington Administrative Code, as amended.

WAC 173-460-040, "Controls of New Sources of Air Toxic Pollutants," Washington Administrative Code, as amended.

WAC-173-460-150, "Table of ASIL, SQER and De Minimis Values", Washington Administrative Code, as amended.

WAC 173-460-160, "Class B Air Toxic Pollutants and Acceptable Source Impact Levels," Washington Administrative Code, as amended.

Wongkasemjit, et.al, "Laboratory Study of Corrosion Effect of Dimethyl Mercury on Natural Gas Processing Equipment," Journal of Corrosion Science and Engineering, Volume 1. Paper 12 (2000.)

24590-WTP-RPT-ENV-01-005, "Best Available Control Technology Analysis for Toxic Air Pollutants for the WTP," Rev 0 (2002) 


\section{Appendix A}

The cost basis used to generate the data for each of the cost estimates for toxic organic compounds, ammonia, and mercury and mercury related compound were developed using previous experience and expertise in ammonia BACT evaluations; and reviewing costs from letter 0401233/DOE-ORP: 04-ED-057 and 24590-WTP-RPT-ENV-01-005, Best Available Control Technology Analysis for Toxic Air Pollutants for the WTP (2002). Specific quote costs were given priority over the report estimated costs, which were 2002 and 2004 vintage, although in several cases where comparisons were made between estimates and quotes; the differences in cost were minor. In addition, equipment cost estimates were based on EPA guidance documents and vendor information. Factors for fabrication from corrosion resistant materials were applied when necessary. Cost estimates do not include disposal of secondary waste or potential posttreatment gas treatment. 
Appendix 1-A Thermal Oxidizer Cost Estimates 


\section{IIS SYSTEMS \\ D) (Thermal Oxidation

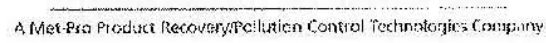

\section{THERMAL OXIDIZER}

Budget Proposal No. 4665

NUCON International, Inc.

DECEMBER 10, 2009
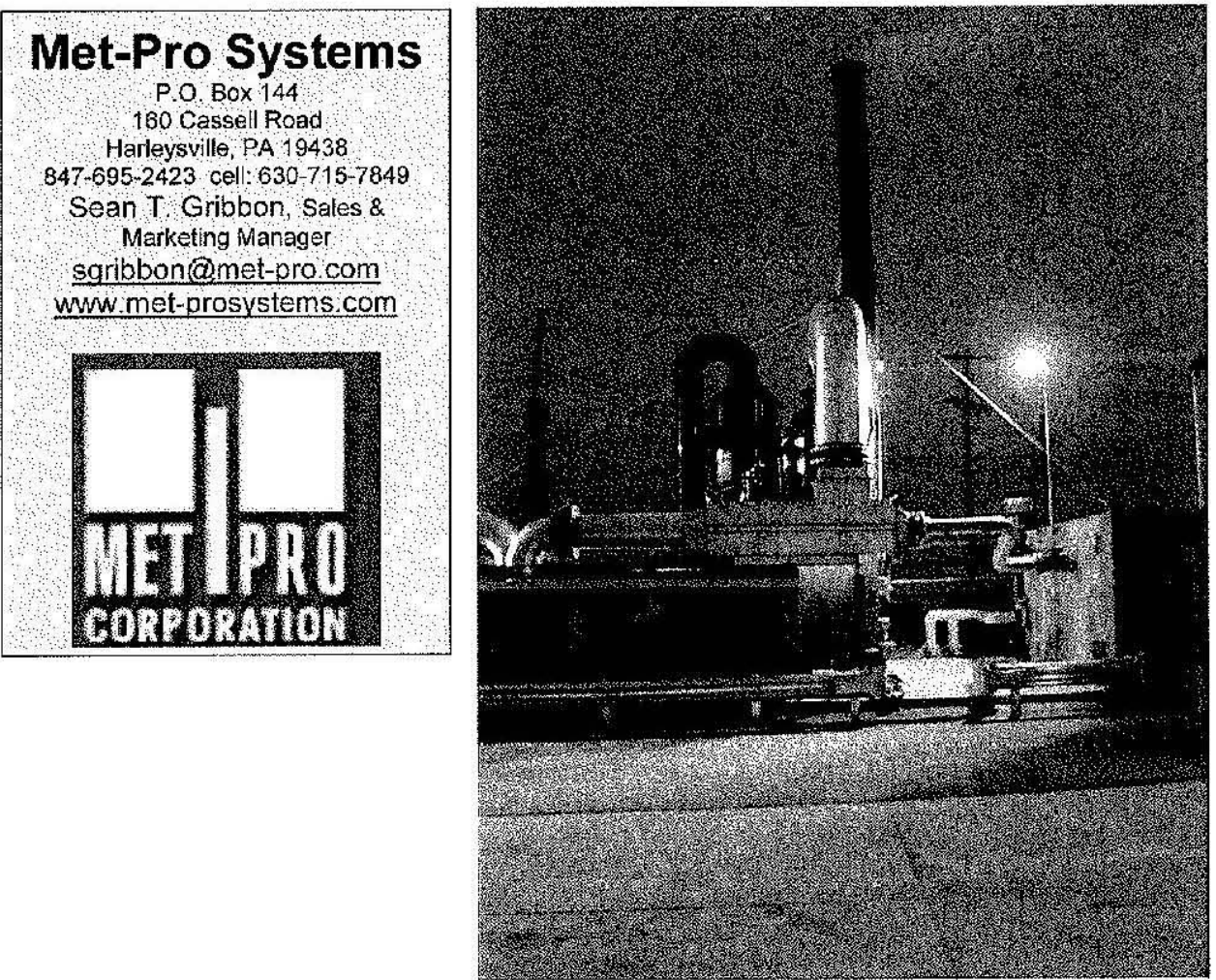


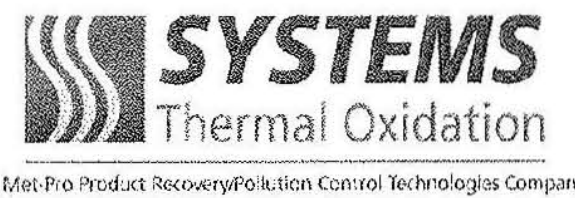

BUDGET PROPOSAL 4665

NUCON International, Inc.

DECEMBER 10, 2009

A Met. Pio Product Rccowerypoltzicn control Yechnologies Company

\section{INTRODUCTION}

\section{COMPANY INTRODUCTION}

Met-Pro Systems is pleased to submit this proposal for your consideration. Met-Pro Corporation, a NYSE listed company headquartered in Pennsylvania, USA is one of the world's leading suppliers of air and fluid purification and handling technology, products and solutions. With 10 divisions and multiple subsidiaries in the USA and Europe, Met-Pro Corporation has the global experience with over 30,000 installations in over 70 countries to provide unequalled integrated product and systems solutions.

Met-Pro Corporation was recently recognized, for the second consecutive year, as one of America's "200 Best Small Companies" by Forbes magazine. Through its business units, in the United States, Canada, Europe and The People's Republic of China, a wide range of products and services are offered for industrial, commercial, municipal and residential markets worldwide. These include product recovery and pollution control technologies for purification of air and liquids; fluid handling technologies for corrosive, abrasive and high temperature liquids; and filtration and purification technologies including proprietary water treatment chemicals and filter products.

Met-Pro Corporation has been recognized for the second consecutive year as one of the world's "Top Small to Midsize Manufacturers" by Start-It magazine. According to Start-It, the "SMB 1200, "is "a complete list of the top small and medium-sized manufacturers in the world". All of the companies that appear on the SMB 1200 have annual revenues between $\$ 40$ million and just under $\$ 1$ billion, and many, according to Start-lt, "have shown intense resilience even as industry continues to face significant market pressures."
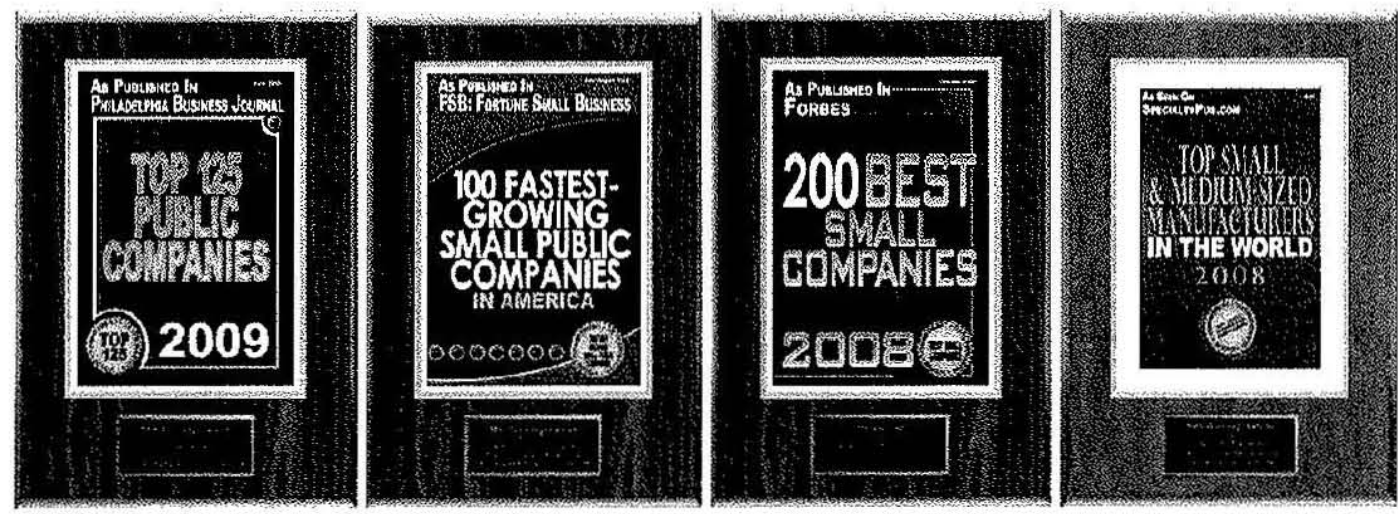

2 
BUDGET PROPOSAL 4665

NUCON International, Inc.

DECEMBER 10, 2009

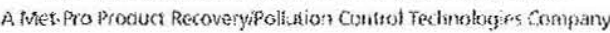

\section{EQUIPMENT DESCRIPTION}

The thermal oxidizer is used to convert hydrocarbons to carbon dioxide and water. This occurs by heating the hydrocarbons in an oxygen rich atmosphere to a temperature that will allow the oxidation reaction to occur at a rapid rate. The thermal oxidizer operates at $2200^{\circ} \mathrm{F}$. The reactants are held at this temperature level for approximately 2 seconds. This will provide a minimum destruction efficiency of $99.99 \%$ of the organic contaminants.

The thermal oxidizer shall be of a cylindrical configuration and mounted horizontally or vertically, depending on required pollution control equipment downstream. Support legs shall be fastened to a foundation with embedded anchor bolts and grouted in place (by others). The casing shall be constructed of carbon steel plate and standard structural shapes. The exterior shall be painted with a single coat of high temperature silicone-based paint and the interior shall be refractory lined.

Air for combustion shall be drawn from ambient air and blended with the process air to achieve a level of oxygen required for flame stability (oxygen in the process is low because of the high water vapor content).

During "Heat-up", "Idle", and "Cool-Down" periods, no waste shall enter the unit. Fresh ambient air shall be forced through the system using the fan. Dampers on the inlet of the fan shall isolate the unit from the process and provide an inlet for the ambient air. Heat-up ramp rate is $50^{\circ} \mathrm{F}$ to $100^{\circ} \mathrm{F}$ per minute. Cold start to operation time is less than 30 minutes.

$\begin{array}{ll}\text { Overall Length: } & 23^{\prime} \\ \text { Casing Diameter: } & 7^{\prime}-4^{\prime \prime} \\ \text { Estimated Equipment Weight: } & 15,000 \text { lbs } \\ \text { Combustion/Dilution Air Connection: } & 14^{\prime \prime} \\ \text { Natural Gas Connection: } & 3^{\prime \prime}\end{array}$

Ancillary equipment for the thermal oxidizer shall include:

- One (1) Nozzle Mix Burner

- One (1) NEMA 12 Control Enclosure with Sub-Panel

- One (1) Allen Bradley SLC5/05 PLC Controller

- One (1) lot of Field Instrumentation for Met-Pro supplied equipment. 


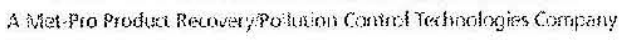

- Interconnecting carbon steel Ductwork with Expansion Joints between Met-Pro Supplied Equipment.

- One (1) Gas Train Assembly with Temperature Control Valve for natural gas

- Class I, Division II Outdoor Electrical Classification

- One (1) Combustion/Dilution Air Blower with Starter

- Two (2) Control Dampers for Combustion and Dilution air

- Two (2) Pneumatic Dampers for Process and Fresh Air Isolation

\section{UTILITIES}

Combustion Air Blower:

Natural Gas Supply:

Compressed Air Supply:

Electrical Power:

Control Power:
$10 \mathrm{hp}$

270 SCFM@10 PSIG

$275 \mathrm{lb} / \mathrm{hr} @ 80 \mathrm{PSIG}$

460 volt / 3 Phase / $60 \mathrm{~Hz}$

120 volt / 1 Phase / $60 \mathrm{~Hz}$

\section{PERFORMANCE}

Destruction and Removal Efficiency of Organic Compounds: $99.99 \%$

\section{SCOPE OF WORK}

Supply by Met-Pro

- Equipment arrangement and design

- Equipment Supply and Fabrication (see "Equipment Description" above)

- Programming of Local control system and HMI

- Operating and Maintenance Manuals

- Installation Instructions 


\section{ISO SYSTEMS ). Thermal Oxidation

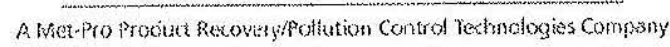

BUDGET PROPOSAL 466 ?

NUCON International, Inc

DECEMBER 10, 200؛

\section{Supply by Others}

The following items are to be supplied by others and are not included in Met-Pro Systems scope of supply:

- Demolition of existing equipment or facilities

- Any modifications to existing equipment

- Building, structural, foundations, anchor bolts, grouting, embedded materials, or any other Civil Design, Materials, and Installation

- Cranes and other tools required for demolition or installation.

- Installation labor and materials

- Design and supply of any equipment upstream of the Thermal Oxidizer.

- Any freeze or personnel protection equipment or materials including insulation and cladding.

- Design and supply of utilities.

- Design, programming, and hardware for integration with plant control system and data acquisition.

- All Interconnecting wiring, conduit, termination, and supports

- All Interconnecting piping, tubing, and supports.

- Interconnecting ductwork and supports for supply to Met-Pro Equipment.

- Transportation and receiving of materials to site

- Installation supervision or commissioning services

Our service department can provide installation supervision and commission services if desired at our standard rates. 
BUDGET PROPOSAL 4665

NUCON International, Inc.

DECEMBER 10, 2009

A Wet Fro Product Recoverypolluticn Control Tedmologies Conphity

\section{PRICING}

The pricing given is for the supply of equipment only. Installation design, labor, materials, and supervision shall be by others.

Met-Pro Supply as described above is:

$\$ 340,000$

\section{Field Supervision, Commissioning, and Training}

Field Supervision, Commissioning, and Training Services are not included in the Met-

Pro Supply price given above. These services are offered at the following rates:

Field Service Personnel.. $\$ 1,500 /$ Day/Person

Travel and Living Expenses. $\$ \operatorname{Cost}+10 \%$

\section{Validity}

Pricing is valid for 30 days, excluding escalation, from the date given on the cover page of this document.

\section{Escalation}

Due to current market volatility in steel, nickel, chrome, copper, precious, and other metals, pricing provided may be subject to escalation at time of Met-Pro issuance of purchase orders to its suppliers. 
BUDGET PROPOSAL 4665

NUCON International, Inc.

DECEMBER 10, 2009

A Merprofrodu Rewerypoliuticn Control rechnologies Company

\section{ENGINEERING AND FABRICATION SCHEDULE}

Based upon current equipment and material availability, we anticipate the following schedule applying to this project:

\section{MILESTONE}

Receipt of purchase order

Drawings for approval

Approval of drawings

Fabrication

Delivery
TIME

6 weeks

2 weeks

16 weeks

1 weeks
ELAPSED TIME

0

6 weeks

8 weeks

24 weeks

25 weeks

This schedule is predicated on customer approval within the time frame noted. Delays in approval will extend the completion date by at least the time equal to the delay. Lengthy delays may result in rescheduling of manufacturing, which could result in a greater offset of shipping dates and increased prices as a result of raw material increases. Shipment timing may change depending upon shop load at the time of order.

\section{COMMERCIAL TERMS}

- $\quad$ All Pricing is in US Dollars.

- All credit subject to approval.

- Payment Terms

$25 \%$ of order upon award

$25 \%$ of order upon complete submittal of the approval drawings

$25 \%$ of order with drawing approval/release to manufacturing

$25 \%$ of order with shipment

Met-Pro Systems Terms and Conditions are attached hereto and form an integral part of this proposal. 


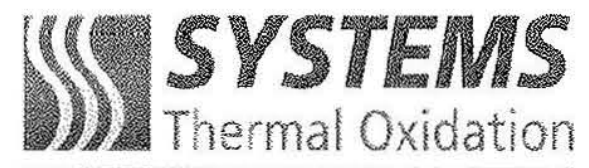

\author{
BUDGET PROPOSAL 4665 \\ NUCON International, Inc. \\ DECEMBER 10, 2009
}

A Net-Pro Prodist Pexoveryspolation Control Techologies Company

\title{
MET-PRO TERMS AND CONDITIONS OF SALE
}

The following terms and conditions form part of each proposal submitted by Met-Pro Corporation, its divisions or subsidiaries, hereinafter called "Seller," for the sale of equipment, machinery, materials, consumables or services (collectively the "Contract Goods") to a Client/Customer, hereafter called "Buyer", and any contract made by and beiween the parties includes as part thereof these terms and conditions. Any provisions or conditions of Buyer's order which are in any way inconsistent with, or in addition to Seller's terms ano conditions shall not be binding on Seller, and shall not be applicable, except with Seller's written acceptance. No changes in, modifications of, or additions to the terms and conditions of this form shall be binding on Seller unless in writing and signed by a representative of Seller duly authorized for that purpose. Any contract resulting from this proposal shall be construed and enforced in accordance with the laws of the Commonwealth of Pennsyivania without giving effect to the choice or conflict of law provisions or ruies thereof. The parties agree that any action arising out of or selating to this sale, shall be brought oniy in the Court of Common Pleas of Montgomery County, Pennsyivania, or the United States District Court for the Eastern Division of Pennsyivania, and hereby consent to venue in such courts.

\section{MATERIAL WARRANTY}

Warranty - Seller warrants to Buyer that the Contract Goods manufactured by it is free from defects in material and workmanship under normal use and service for a period of eighteen (18) months after shipment or twelve (12) months after initial operation, whichever occurs first, or for such period of time as is specifically provided for on the face of the written quotation or order form, and for no additional period of time unless Seller expressly agrees in writing to a longer warranty. All auxiliary equipment not manufactured by Seller carries such warranty as given by the manufacturer thereof and which is hereby assigned to Buyer without recourse to Seller. Seller's warranty for consumables shall be prorated over the applicable aforementioned period.

No warranty is offered as to refractories or protective coatings, other than the material composition is in compliance with specifications

Terms - Upon discovery of defecis in materials or workmanship during such eighteen (18) months after shipment or twelve (12) months after initial operation as described above, Seller shall either repair or replace the equipment, on the condition that the conditions set forth immediately below are met. Even if Seller repairs or replaces the equipment, its original warranty term is not extended. Seller's obligation under this warranty is, at Seller's sole option, to a one-time repair or replacement of any part which is shown to Seller's reasonable satisfaction to have been defective as to material, workmanship or design, provided that:

1. Written notice of such defect is given to Seller within ten (10) calendar days of discovery thereof;

2. the equipment has been installed and operaled $n$ accordance with the purpose for which it was purchased and the installation, operating and maintenance instructions provided by Seller:

3. no alterations or substitutions have been made in the equipment;

4. Seller may require the return of the defective material to establish any claim or make repairs but in no event shall the material be returned without Seller's consent. All returned equipment or parts must be free from any hazardous materials;

5. No payment or allowances wili be made for repairs or alterations in the equipment unless Seller's prior written approval has been oblained. All removal, shipping, and reinstallation cosis shall be to Buyer's account; and

6. Selfer shall not be required to honor any warranty obligation until such time as it shall have been paid in full by Buyer.

\section{PATENT WARRANTY}

Seller shall defend at its expense any suit or proceeding brought against Buyer based on any claim that the equipment manufactured by Seller, except for equipment/material manufactured and/or designed to Buyer's specifications, infringes any Unifed States patent issued as of the date of the proposal or contract provided Buyer gives to Seller immediate notice in writing of the instilution of the suit or proceedings and permits Seller, through its Counsel, to defend the same and gives Seller all needed information, assistance and authority to enable Seller to do so. On any equipment or component manufactured by others, Seller shall pass through any patent indemnity offered by said manufacturer. Seller's liability shall be limited to rendering reasonable assistance to Buyer to enforce said indemnity, which term shall not be deemed to include the payment of any fees or expenses of Buyer's legal counsel or to require Seller to institute suit or to participate in any such litigation.

IMPLIED WARRANTIES AND DISCLAIMER

THE WARRANTIES FURNISHED BY SELLER AS EXPRESSLY INCLUDED I-IEREIN CONSTITUTE SELLLER'S SOLE OBLIGATION HEREUNDER AND ARE IN LIEU OF ANY OTHER WARRANTIES EXPRESSED OR IMPLIED, INCLUDING WITHOUT LIMITATION 


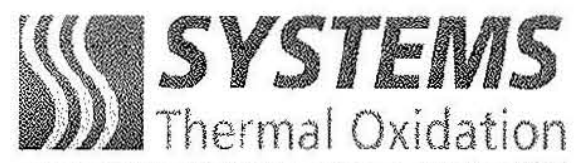

BUDGET PROPOSAL 4665
NUCON International, Inc.
DECEMBER 10, 2009

A Mest-pro Produci Recoverypolution Control Tecinolcgies Company

WARRANTIES OF MERCHIANTABILITY OR FITNESS FOR A PARTICULAR PURPOSE, EVEN IN THE EVENT OF A FUNDAMENTAL BREACH BY SELLER. THERE ARE NO WARRANTIES, WHICH EXTEND BEYOND THE DESCRIPTION ON THE FACE HEREOF.

\section{DISCLAIMER OF WARRANTIES}

SELLER SHALL NOT BE LIABLE TO BUYER OR BUYER'S CUSTOMER FOR INCIDENTAL, CONSEQUENTIAL OR LIQUIDATED

DAMAGES INCLUDING, BUT NOT LIMITED TO, LOSS OF PROFITS OR REVENUE, LOSS OF USE OF CONTRACT GOODS, COSTS OF REPLACEMENT POWER OR CONTRACT GOODS, ADDITIONAL EXPENSES INCURRED IN THE USE OF CONTRACT GOODS OR

FACII ITIES, OR THE CLAIMS OF THIRD PARTIES, EVEN IF SELLER HAS BEEN ADVISED OF POSSIBILITY OF SUCH DANAGGES. THIS OISCLAIMER SHALL APPLY TO INCIDENTAL, CONSEQUFNTIAL OR LIQUIDATED DAMAGES BASED UPON ANY CAUSE OF ACTION WHATSOEVER ASSERTED AGAINST SELLER, INCLUDING ONE ARISING OUT OF PRINCIPLES OF CONTRACT, ANY BREACH OF WARRANTY, EXPRESSED OR IMPLIED, GUARANTEE, EQUIPNENT OR OTHER CONTRACT GOODS LIABILITY, NEGLIGENCE, TORT, OR ANY OTHER CAUSE PERTAINING TO PERFORMANCE OR NON-PERFORMANCE TO THE PROPOSAL OR CONTRACT BY SELLER. BUYER SHALL. HOLD SELLER HARMLESS FROM ANY SUCH CLAIMS BY BUYER'S CUSTOMER.

\section{INSPECTION}

If upon receipt of the Contract Goods by Buyer, the same shall not conform to Buyer's order, Buyer shall notify Seller in writing within ten (10) days from receipt of the Contract Goods and before any part of the Contract Goods has been changed from its original condition. Such notification shall provide detailed information as to the nonconformity or shortage and Buyer shall hold the Contraci Goods for Seller's disposition and afford Seller a reasonable opportunity to inspect the Contract Goods. Seller may, at its option, replace without charge, refund the purchase price, or make a fair allowance for defects or shortages demonstrated to Seller's satisfaction to have existed at the time of delivery. Seller may require the return of the Contract Goods to establish any claim but in no event shall Contract Goods be returned without Seiler's consent.

\section{LIMITATION OF LIABILITY OF SELLER}

In addition to the other limitations on Seller's liability provided for herein, in no event will Seller's liability to Buyer for any and all claims, including property damage or personal injury c:aims, allegedly resulting from breach of contract, warranty, strict liability, tort, or any other theory of liability involving this proposal or contract exceed the amount of the purchase price paid to Seller.

\section{PRICE}

1. Prices are F.O.B. point of shipment

2. Oral and written quotations are subject to acceptance within thirty $\{30$ ) days from date.

3. Prices on equipment of Seller's manufacture are firm, provided it is shipped within the quoted and agreed upon shipment schedule. If Buyer causes shipment to be delayed Seller reserves the right to invoice at Seller's price effective at time of shipment.

4. Any excise, sales, use taxes or other taxes imposed by Federal, State, or municipal authority and incurred by Seller applicable to the malerial sold, shall be to Buyer's account and are in addition to the prices qusoted, unless Buyer provides Seller with a proper taxexemption certificate. Buyer hereby agrees to indemnify, defend and hold harmless Seller from any taxes, fines, penalties and costs, including attorneys' fees, incurred or paid by Seller arising out of an!y such claim of exemption. This defense and indemnity requirement shall survive this contract and any releases resulting from same.

TERMS

Terms of payment are in accordance with the proposed payment terms and are payable 30 days net from the date of invoice

For late payment, Buyer is subject to a late charge of eighteen percent (18\%) of the unpaid fees per annum (1.5\% per month) or the maximum allowed by law, whichever is less.

If Seller does not receive payment in full for the Contract Goods and any monies otherwise dise by the due date then Seller may. at its option at any time while the whole or any part of the monies due remain outstanding, take possession of the Contract Goods, or any part, delay or stop future deliveries, and terminate this agreement, in which case Seller is entitled to recovor any loss, including loss of profit, which loss will carry interest under paragraph 2 of this Section.

Pro rata retainage fees or backcharges will not be accepted by Seller.

Buyer will be responsible for all expenses incurred from any collection proceedings.

\section{DELIVERY}

Delivery dates are estimated by Seller on the basis of the best available information and cannot be guaranteed.

Where Contract Goods are delivered in multiple deliveries, Seller may deem each delivery to be a separate contract, and no defautt or fallure by Selter in respect of any ane or more insiallments shall vitiate any contracts with respect to Contract Goods previously delivered or undelivered. 


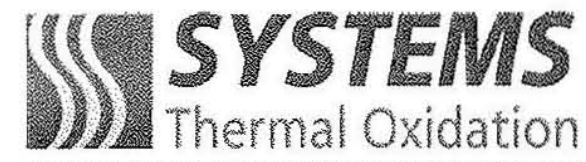

BUDGET PROPOSAL 4665
NUCON International, Inc.
DECEMBER 10, 2009

A Wiet. Pro Product Recoverypolition Control Technolagies Company

Force Majeure - Seller shall not he liable for any loss or damage arising out of delay in shipmest or delivery, or failure to manufacture, or failure of equipment to operate, due to causes beyond its reasonable control, such as but not limited to. Acts of God, Acts of Buyer, Acts of Civil or Misitary Authority, priorities, fires, strikes, floods, epidemics, quarantine restrictions, war, riot. delays in transportation, car shortages, and Seller's inability to obtain necessary labor, materials, or manufacturing facilities. In the event of any such delay, the date of delivery shall be extended for a period ecual to the time lost by reason of the delay and Seller shal! be entitled to an equitabie adjustment in the sales price for increased costs incurred.

All risk of loss or damage to Contract Goods furnished hereunder shall pass to Buyer, F.O.B. point of shipment.

Seller reserves the right to ship all or any part of the Contract Goods from any stipping point of any of its sources of supply other than the shipping point specified herein. Shipment will be made by the method or carrier deemed most feasible by Seller unless othervise requested in writing by Buyer.

\section{GRANT OF SECURITY INTEREST}

As security for the payment in full for the Contract Goods, as a condition of the passage of title to Buyer for the Contract Goods as provided for hereunder, Buyer grants to Seller a first priority security interest in the Contract Goods, wherever located, together with all Accounts, Products and Proceeds of any and all of the Contract Goods (as such terms are defined by the Uniform Commercial Code as from time to time in effect in any applicable jurisdiction). Upon default in payment by Buyer, Seller may exercise all rights of a Secured Party as provided for by the Uniform Commercial Code.

\section{CANCELLATION}

Cancellation of order by Buyer, or any part thereof. will not be effective unless accepted by Seller in writing. Accepted cancellation will be subject to a charge to cover all cosis incurred to the date of acceptance, plus reasonable vancellation costs, plus profit on the completed work.

\section{SUSPENSION}

In the event Buyer suspends the execution of work, Buyer shall reimburse Seller for all costs incurred by Seller as a resull of such suspension, including, without limitation, all borrowing and opportunity costs. In the event the suspension exceeds 180 days in duration, in addition to being entitled to full reimbursement of costs as aforesaid, Selter shatl have the unqualified right to cancel the unfinished portion of the contract without liability to Buyer of any kind.

\section{GENERAL CONDITIONS}

1. Non-stock Contracl Goods made specifically to order are not subject to return for credit. Any portion of non-stock Contract Goods in process of manufacture is not subject to cancellation. Any charges after manufacture has started could necessitate additional charges for work done and material consumed.

2. Quotations are merely negotiations to trade and not offers to contract.

3. Seller reserves the right to correct any factory, engineering, clerical and/or stenographic errors or omissions

4. Changes in design are made af Seller's discretion. Seller has no obligation to incorporate these changes in units manufactured prior to the change.

5. It is expressly understood that any and all drawings, instructions, and/or technical and engineering services, which Seller may furnish with reference to the installation or use of its Contract Goods, are furnished solely for the review and approval of Buyer and its engineers. Seller makes no represenlation or warranty with respect to the accuracy or sufficiency of any such information and assumes no obligation or liability for results oblained.

6. Waiver by Seller of a breach of any of these Terms and Conditions shail not be construed as a waiver of any other breach.

7. To combat corrosion, abrasion, or erosion, or operation at elevated temperalures, any such recommendations will be based on the best avaliable experience of Seller and the supplier of the material, BUT WILL NOT CONSTITUTE A GUARANTEE AGAINST THESE EFFECTS 
Appendix 1-B Thermal Non-Catalytic Cost Estimates 
24590-WTP-RPT-ENV-01-005, Rev. 0 Best Available Control Technology Analysis fot roxic Air Pollutants for the WTP

Table B-4. TBACT Control Technology Cost Estimate Thermal Noncatalytic Oxidation Stream S120 HLW Melter Offgas Unabated

\begin{tabular}{|c|c|c|c|}
\hline Cost Item & Basis & & Example Cust \\
\hline \multicolumn{4}{|l|}{ Direct Costs } \\
\hline \multicolumn{4}{|l|}{ Purchased Equipment Costs } \\
\hline Equipment & & & $\$ 382,316.00$ \\
\hline Required Ancillary Equipment & & & $\$ 0.00$ \\
\hline Instrumentation and Control & $15 \%$ of Equipment & & $\$ 57,347.40$ \\
\hline Freight & $5 \%$ of Equipment & & $\$ 19,115.80$ \\
\hline Subtotal Purchased Equipment Costs (PEC) & & & $\$ 458,779.20$ \\
\hline \multicolumn{4}{|l|}{ Direct Installation Costs } \\
\hline Foundations \& Supports & $8 \%$ of Subtotal PEC & & $\$ 36,702.34$ \\
\hline Handling \& Erection & $14 \%$ of Subtotal PEC & & $\$ 64,229.09$ \\
\hline Electrical & $4 \%$ of Subtotal PEC & & $\$ 18,351.17$ \\
\hline Piping and Duct Work & $4 \%$ of Subtotal PEC & & $\$ 18,351.17$ \\
\hline Insulation for Piping \& Equipment & $4 \%$ of Subtotal PEC & & $\$ 18,351.17$ \\
\hline Painting & $2 \%$ of Subtotal PEC & & $\$ 9.175 .58$ \\
\hline Subtotal Installation Costs (IC) & & & $\$ 165,160.51$ \\
\hline $\begin{array}{l}\text { Site Preparation } \\
\text { Building Costs }\end{array}$ & $\begin{array}{l}\text { Equipment Specific } \\
\text { see cost factors below }\end{array}$ & equipment size & $\$ 20,000.00$ \\
\hline C 5 Location per square foot & $\$ 1,388 / \mathrm{sf}$ & $66 \mathrm{sf}$ & $\$ 91.608 .00$ \\
\hline Subtotal - Building (per highest applicable cost area) & Equipment Specific & & $\$ 91,608.00$ \\
\hline Total Direct Cost & & & $\$ 735,547.71$ \\
\hline \multicolumn{4}{|l|}{ Indirect Costs (Installation) } \\
\hline Engineering & $10 \%$ of PEC & & $\$ 45,877.92$ \\
\hline Construction and Field Expenses & $5 \%$ of PEC & & $\$ 22,938.96$ \\
\hline Start-up & $10 \%$ of PEC & & $\$ 45,877.92$ \\
\hline Performance Tests & $1 \%$ of PEC & & $\$ 4,587.79$ \\
\hline Contingencies & $15 \%$ of PEC & & $\$ 68,816.88$ \\
\hline Total Indirect Costs & & & $\$ 188,099.47$ \\
\hline Total Capital Costs (TCC) & & & $\$ 923,647.18$ \\
\hline
\end{tabular}

Source: Modified from EPA Handbook Control Technologies for Hazardous Air Pollutanis (June 1991) 
24590-WTP-RPT-ENV-01-005, Rev. 0 Best Available Control Technology Analysis for Toxic Air Pollutants for the WTP

Table B-4. TBACT Control Technology Cost Estimate Thermal Noncatalytic Oxidation

Stream S120 HLW Melter Offgas Unabated

\begin{tabular}{|c|c|c|}
\hline Cost Item & Factor & Example Cost \\
\hline \multicolumn{3}{|l|}{ Direct Annual Costs } \\
\hline \multicolumn{3}{|l|}{ Utilities } \\
\hline Electricity & $\$ 0.08 / \mathrm{kWhr}$ & $\$ 5,000.00$ \\
\hline Steam & $\$ 6.00 / 1000 \mathrm{lb}$ & $\$ 0.00$ \\
\hline Water & $\$ 0.25 / 1000 \mathrm{gal}$ & $\$ 0.00$ \\
\hline Materials/Chemicals & & $\$ 52,013.00$ \\
\hline \multicolumn{3}{|l|}{ Operating Expenses } \\
\hline Operator & $\$ 20 / \mathrm{Hr}$ & $\$ 1,040.00$ \\
\hline Supervisor & $15 \%$ of Operator & $\$ 156.00$ \\
\hline Secondary Waste T\&D & Process Specific & $\$ 100,000.00$ \\
\hline \multicolumn{3}{|l|}{ Maintenance } \\
\hline Labor & $24 \mathrm{hr} / 2 \mathrm{yr}$ & $\$ 204.00$ \\
\hline Materials & $100 \%$ of Maintenance Labor & $\$ 204.00$ \\
\hline \multicolumn{3}{|l|}{ Indirect Annual Costs } \\
\hline Overhead & $6 \%$ of Labor Costs & $\$ 840.00$ \\
\hline Administrative & $2 \%$ of TCC & $\$ 18,472.94$ \\
\hline Insurance & $1 \%$ of TCC & $\$ 9,236.47$ \\
\hline Total Annual Costs (TAC) & & $\$ 187,166.42$ \\
\hline Rate of Return on Capital Investment & $10.00 \%$ & \\
\hline Service Life (years) & 40 & \\
\hline Capital Recovery Factor & 0.1023 & \\
\hline Annualized Capital Investment ( $\mathrm{ACl})$ & & $\$ 94,451.62$ \\
\hline Grand Total Annualized Costs & $\mathbf{A C I}+\mathrm{TAC}$ & $\$ 281,618.04$ \\
\hline
\end{tabular}

Source: Modified from EPA Handbook Control Technologies for Hazardous Air Pollutants (June 1991). 
24590-WTP-RPT-ENV-01-005, Rev. 0 Best Available Control Technology Analysis for Toxic Air Pollutants for the WTP

Table B-4. TBACT Control Technology Cost Estimate

Thermal Noncatalytic Oxidation

Stream S74/S1

LPP LAW Melter Feed Evaporator

\begin{tabular}{|c|c|c|c|}
\hline Cost Item & Basis & & Example Cost \\
\hline \multicolumn{4}{|l|}{ Direct Costs } \\
\hline \multicolumn{4}{|l|}{ Purchased Equipment Costs } \\
\hline Equipment & & & $\$ 427,609.00$ \\
\hline Required Ancillary Equipment & & & $\$ 0.00$ \\
\hline Instrumentation and Control & $15 \%$ of Equipment & & $\$ 64,141.35$ \\
\hline Freight & $5 \%$ of Equipment & & $\$ 21,380.45$ \\
\hline Subtotal Purchased Equipment Costs (PEC) & & & $\$ 513,130.80$ \\
\hline \multicolumn{4}{|l|}{ Direct Installation Costs } \\
\hline Foundations \& Supports & $8 \%$ of Subtotal PEC & & $\$ 41,050.46$ \\
\hline Handling \& Erection & $14 \%$ of Subtotal PEC & & $\$ 71,838.31$ \\
\hline Electrical & $4 \%$ of Subtotal PEC & & $\$ 20,525.23$ \\
\hline Piping and Duct Work & $4 \%$ of Subtotal PEC & & $\$ 20,525.23$ \\
\hline Insulation for Piping \& Equipment & $4 \%$ of Subtotal PEC & & $\$ 20,525.23$ \\
\hline Painting & $2 \%$ of Subtotal PEC & & $\$ 10,262.62$ \\
\hline Subtotal Installation Costs (IC) & & & $\$ 184,727.09$ \\
\hline Site Preparation & Equipment Specific & & $\$ 20,000.00$ \\
\hline Building Costs & see cost factors below & equipment size & \\
\hline C5 Location per square foot & $\$ 1,388 / \mathrm{sf}$ & $88 \mathrm{sf}$ & $\$ 122,144.00$ \\
\hline Subtotal - Building (per highest applicable cost area) & Equipment Specific & & $\$ 122,144.00$ \\
\hline Total Direct Cost & & & $\$ 840,001.89$ \\
\hline \multicolumn{4}{|l|}{ Indirect Costs (Installation) } \\
\hline Engineering & $10 \%$ of PEC & & $\$ 51,313.08$ \\
\hline Construction and Ficld Expenses & $5 \%$ of PEC & & $\$ 25,656.54$ \\
\hline Start-up & $10 \%$ of PEC & & $\$ 51,313.08$ \\
\hline Performance Tests & $1 \%$ of PEC & & $\$ 5,131.31$ \\
\hline Contingencies & $15 \%$ of PEC & & $\$ 76,969.62$ \\
\hline Total Indirect Costs & & & $\$ 210,383.63$ \\
\hline Total Capital Costs (TCC) & & & $\$ 1,050,385.52$ \\
\hline
\end{tabular}

Source: Modified from EPA Handbook Control Technologies for Hazardous Air Pollutants (June 1991).

Page B-226 
24590-WTP-RPT-ENV-01-005, ReV. 0 Best Available Control Technology Analysis for Toxic Air Pollutants for the WTP

Table B-4. TBACT Control Technology Cost Estimate Thermal Noncatalytic Oxidation

Stream $\mathrm{S41Z}$

PT Vessel Vents Unabated

\begin{tabular}{|c|c|c|}
\hline Cost Item & Basis & Example Cost \\
\hline \multicolumn{3}{|l|}{ Direct Costs } \\
\hline \multicolumn{3}{|l|}{ Purchased Equipment Costs } \\
\hline Equipment & & $\$ 393,515.00$ \\
\hline Required Ancillary Equipment & & $\$ 0.00$ \\
\hline Instrumentation and Control & $15 \%$ of Equipment & $\$ 59,027.25$ \\
\hline Freight & $5 \%$ of Equipment & $\$ 19,675.75$ \\
\hline Subtotal Purchased Equipment Costs (PEC) & & $\$ 472,218.00$ \\
\hline \multicolumn{3}{|l|}{ Direct Installation Costs } \\
\hline Foundations \& Supports & $8 \%$ of Subtotal PEC & $\$ 37,777.44$ \\
\hline Handling \& Erection & $14 \%$ of Subtotal PEC & $\$ 66,110.52$ \\
\hline Electrical & $4 \%$ of Subtotal PEC & $\$ 18,888.72$ \\
\hline Piping and Duct Work & $4 \%$ of Subtotal PEC & $\$ 18,888.72$ \\
\hline Insulation for Piping \& Equipment & $4 \%$ of Subtotal PEC & $\$ 18,888.72$ \\
\hline Painting & $2 \%$ of Subtotal PEC & $\$ 9,444,36$ \\
\hline Subtotal Installation Costs (IC) & & $\$ 169,998.48$ \\
\hline $\begin{array}{l}\text { Site Preparation } \\
\text { Building Costs }\end{array}$ & $\begin{array}{l}\text { Equipment Specific } \\
\text { see cost factors below equipment size }\end{array}$ & $\$ 20,000.00$ \\
\hline C5 Location per square foot & $\$ 1,388 / \mathrm{sf}$ & $\$ 91.608 .00$ \\
\hline Subtotal - Building (per highest applicable cost area) & Equipment Specific & $\$ 91,608.00$ \\
\hline Total Direct Cost & & $\$ 753,824.48$ \\
\hline \multicolumn{3}{|l|}{ Indirect Costs (Installation) } \\
\hline Engineering & $10 \%$ of PEC & $\$ 47,221.80$ \\
\hline Construction and Field Expenses & $5 \%$ of PEC & $\$ 23,610.90$ \\
\hline Start-up & $10 \%$ of $\mathrm{PEC}$ & $\$ 47,221.80$ \\
\hline Performance Tests & $1 \%$ of PEC & $\$ 4,722.18$ \\
\hline Contingencies & $15 \%$ of PEC & $\$ 70,832.70$ \\
\hline Total Indirect Costs & & $\$ 193,609.38$ \\
\hline Total Capital Costs (TCC) & & $\$ 947,433.86$ \\
\hline
\end{tabular}

Source: Modified from EPA Handbook Control Technologies for Hazardous Air Pollutants (June 1991).

Page B-170 
24590-WTP-RPT-ENV-01-005, Rev. 0 Best Available Control Technology Analysis for Toxic Air Pollutants for the WTP

Table B-4. TBACT Control Technology Cost Estimate

Thermal Noncatalytic Oxidation

Stream S74/S1

LPP LAW Melter Feed Evaporator

\begin{tabular}{|c|c|c|}
\hline Cost Item & Factor & Example Cost \\
\hline \multicolumn{3}{|l|}{ Direct Annual Costs } \\
\hline \multicolumn{3}{|l|}{ Utilities } \\
\hline Electricity & $\$ 0.08 / \mathrm{kWhr}$ & $\$ 5,000,00$ \\
\hline Steam & $\$ 6.00 / 1000 \mathrm{lb}$ & $\$ 0.00$ \\
\hline Water & $\$ 0.25 / 1000$ gal. & $\$ 0.00$ \\
\hline Materials/Chemicals & & $\$ 74,019.00$ \\
\hline \multicolumn{3}{|l|}{ Operating Expenses } \\
\hline Operator & $\$ 20 / \mathrm{Hr}$ & $\$ 1,040.00$ \\
\hline Supervisor & $15 \%$ of Operator & $\$ 156.00$ \\
\hline Secondary Waste T\&D & Process Specific & $\$ 100,000.00$ \\
\hline \multicolumn{3}{|l|}{ Maintenance } \\
\hline Labor & $24 \mathrm{hr} / 2 \mathrm{yr}$ & $\$ 204.00$ \\
\hline Materials & $100 \%$ of Maintenance Labor & $\$ 204.00$ \\
\hline \multicolumn{3}{|l|}{ Indirect Annual Costs } \\
\hline Overhead & $6 \%$ of Labor Costs & $\$ 840.00$ \\
\hline Administrative & $2 \%$ of TCC & $\$ 21,007.71$ \\
\hline Insurance & $1 \%$ of TCC & $\$ 10,503.86$ \\
\hline Total Annual Costs (TAC) & & $\$ 212,974.57$ \\
\hline Rate of Return on Capital Investment & $10.00 \%$ & \\
\hline Service Life (years) & 40 & \\
\hline Capital Recovery Factor & 0.1023 & \\
\hline Annualized Capital Investment (ACI) & & $\$ 107,411.81$ \\
\hline Grand Total Annualized Costs & $\mathbf{A C I}+\mathbf{T A C}$ & $\$ 320,386.37$ \\
\hline
\end{tabular}

Source: Modified from EPA Handbook Control Technologies for Hazardous Air Pollutants (June 1991). 
24590-WTP-RPT-ENV-01-005, Rev. 0 Best Available Control Technology Analysis for

Toxic Air Pollutants for the WTP

Table B-4. TBACT Control Technology Cost Estimate

Thermal Noncatalytic Oxidation

Stream $\mathrm{S41Z}$

PT Vessel Vents Unabated

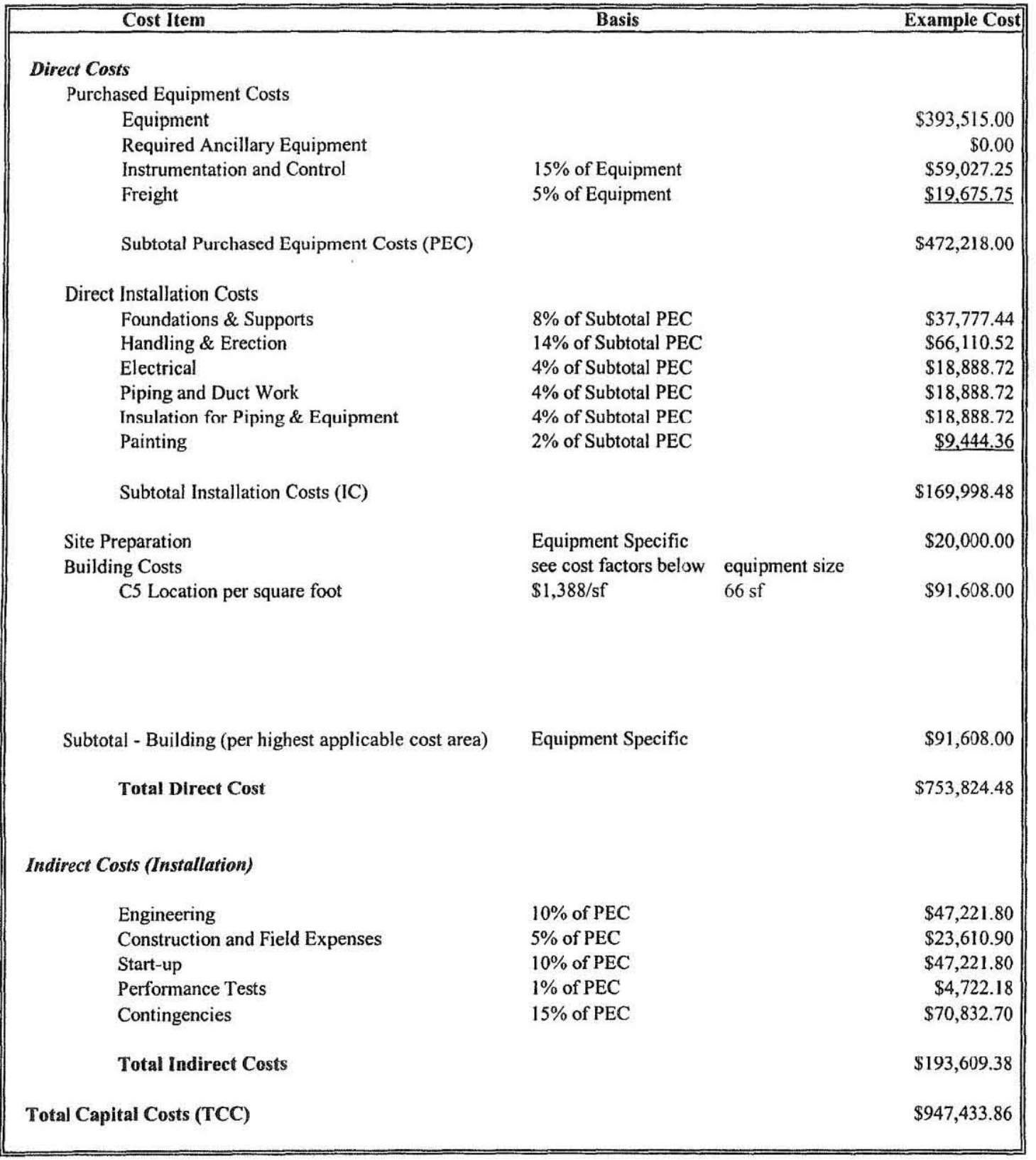

Source: Modified from EPA Handbook Control Technologies for Hazardous Air Pollutants (June 1991).

Page B-170 
24590-WTP-RPT-ENV-01-005, ReV. 0 Best Available Control Technology Analysis for Toxic Air Pollutants for the WTP

Table B-4. TBACT Control Technology Cost Estimate

Thermal Noncatalytic Oxidation

Stream S41Z

PT Vessel Vents Unabated

\begin{tabular}{|c|c|c|}
\hline Cost Item & Factor & Example Cost \\
\hline \multicolumn{3}{|l|}{ Direct Annual Costs } \\
\hline \multicolumn{3}{|l|}{ Utilities } \\
\hline Electricity & $\$ 0.08 / \mathrm{kWhr}$ & $\$ 5,000.00$ \\
\hline Steam & $\$ 6.00 / 1000 \mathrm{lb}$ & $\$ 0.00$ \\
\hline Water & $\$ 0.25 / 1000$ gal. & $\$ 0.00$ \\
\hline Materials/Chemicals & & $\$ 52,013.00$ \\
\hline \multicolumn{3}{|l|}{ Operating Expenses } \\
\hline Operator & $\$ 20 / \mathrm{Hr}$ & $\$ 1,040.00$ \\
\hline Supervisor & $15 \%$ of Operator & $\$ 156.00$ \\
\hline Secondary Waste T\&D & Process Specific & $\$ 0.00$ \\
\hline \multicolumn{3}{|l|}{ Maintenance } \\
\hline Labor & $24 \mathrm{hr} / 2 \mathrm{yr}$ & $\$ 204.00$ \\
\hline Materials & $100 \%$ of Maintenance Labor & $\$ 204.00$ \\
\hline \multicolumn{3}{|l|}{ Indirect Annual Costs } \\
\hline Overhead & $6 \%$ of Labor Costs & $\$ 840.00$ \\
\hline Administrative & $2 \%$ of TCC & $\$ 18,948.68$ \\
\hline Insurance & $1 \%$ of TCC & $\$ 9,474.34$ \\
\hline Total Annual Costs (TAC) & & $\$ 87,880.02$ \\
\hline Rate of Return on Capital Investment & $10.00 \%$ & \\
\hline Service Life (years) & 40 & \\
\hline Capital Recovery Factor & 0.1023 & \\
\hline Annualized Capital Investment (ACI) & & $\$ 96,884.03$ \\
\hline Grand Total Annualized Costs & $\mathbf{A C I}+\mathbf{T A C}$ & $\$ 184,764.05$ \\
\hline
\end{tabular}

Source: Modified from EPA Handbook Control Technologies for Hazardous Air Pollutants (June 1991). 


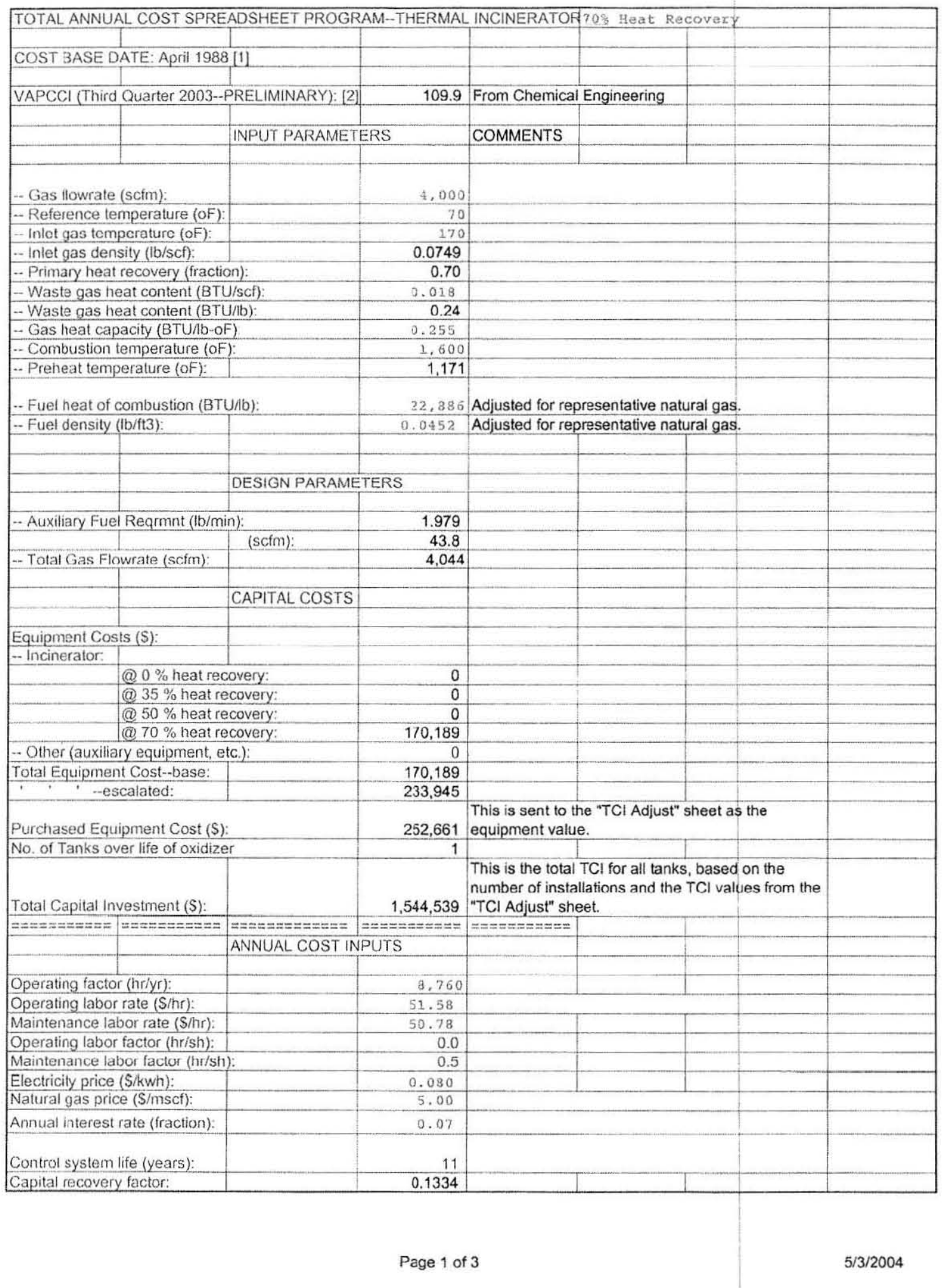




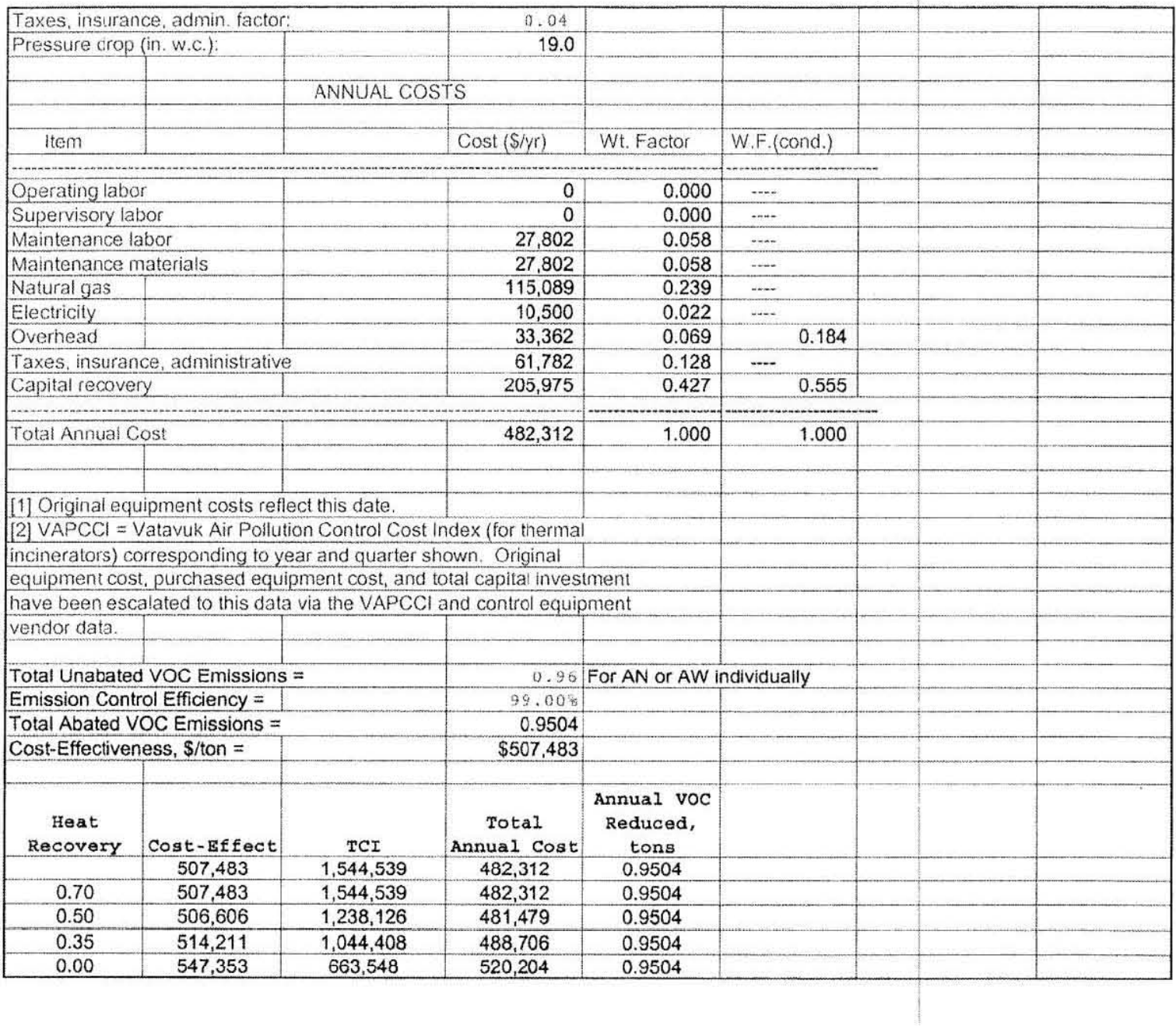




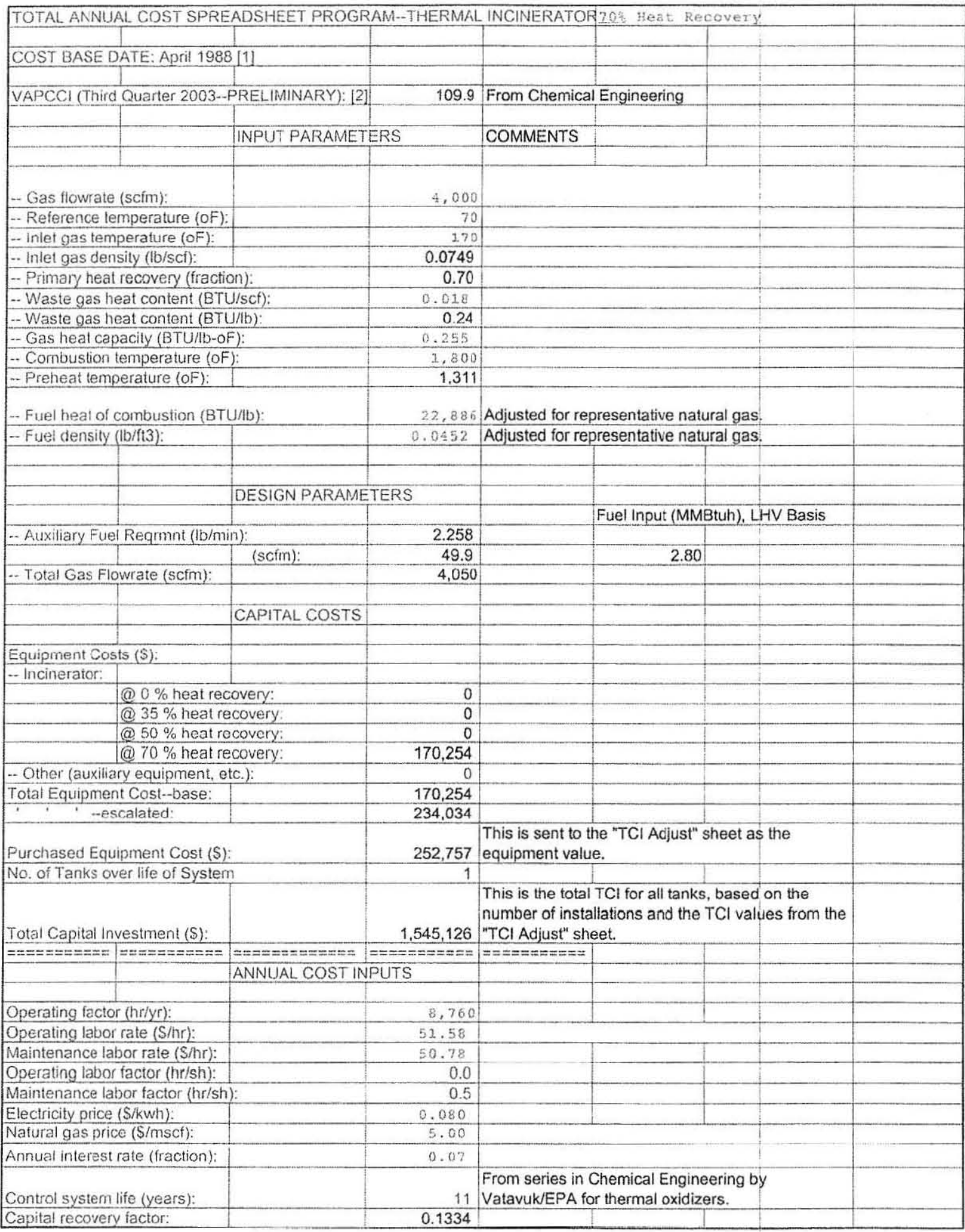




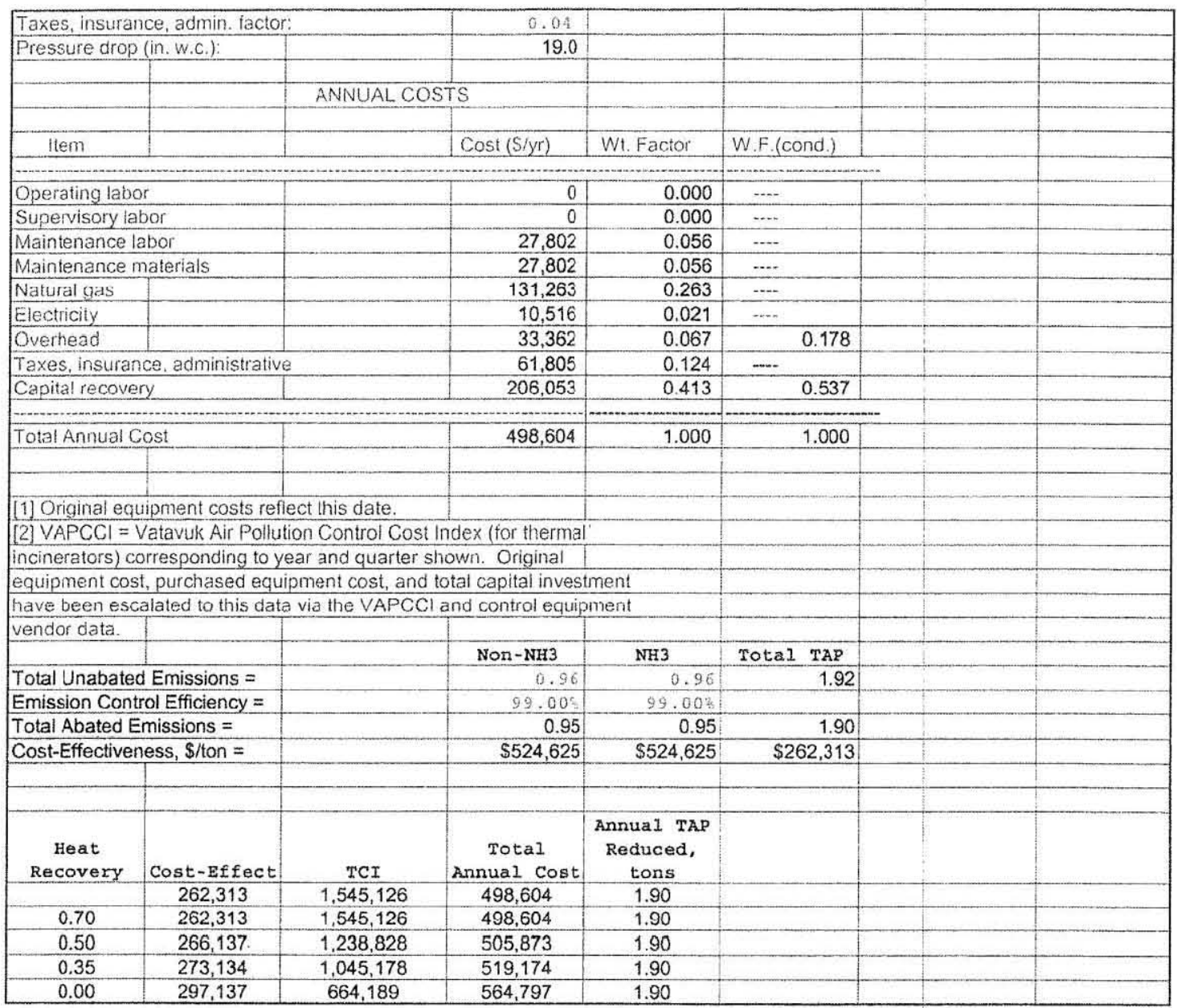




\section{Appendix 1-C Adsorber Costs}




\section{NUCON International, Inc 7000 Huntley Road \\ Columbus, $\mathrm{OH} 43229$}

Phone: 614-846-5710

Fx: 614-431-0858

www.nucon-int.com

\section{QUOTATION/PROPOSAL}

Proposal No.:

Attachments:
12328

Vessel Description Adsorbent data sheet
Date:

Exp. Date:
12 Apr 10

12June 10

Name:

Phone:

Fax:

Email:

Company: Columbia Nuclear International LLC

Address:

\begin{tabular}{|l|l|l|l|r|}
\hline Ref & \multicolumn{1}{|c|}{ Description } & Qty. & Unit Price & Total Price \\
\hline & $\begin{array}{l}\text { Adsorber vessel per attached description with 11,000 lbs } \\
\text { of NUCON MERSORB 3 Mercury Adsorbent }\end{array}$ & lot & $\$ \mathbf{2 4 7 , 0 0 0}$ & $\mathbf{\$ 2 4 7 , 0 0 0}$ \\
\hline & & & & \\
\hline & Terms: Net 30 days & & & \\
\hline & Shipment: 20 weeks after drawing approval & & & \\
\hline & FOB: Columbus, OH & & & \\
\hline & & & & \\
\hline & & & & \\
\hline & & & & \\
\hline & & & & \\
\hline & & & & \\
\hline & & & & \\
\hline & & & & \\
\hline & & & & \\
\hline & & & & \\
\hline & & & & \\
\hline & & & & \\
\hline
\end{tabular}

\begin{tabular}{|l|l|l|l|}
\hline Please Contact: & Joe Enneking & Phone Ext.: 111 & Email: joe.enneking@nucon-int.com \\
\hline
\end{tabular} 
Date: $24-F e b-10$

\section{NUCON International, Inc. \\ 7000 Huntley Road, Columbus OH 43229}

Phone: 614-846-5710 FAX: 614-431-0858 Internet: www.nucon-int.com Preliminary Design for a Vertical Adsorber with ASME Flanged \& Dished Heads

Client: Hanford $\mathrm{Hg}$ Adsorber

Fluid Properties:

Fluid flow rate, lb.hr

Fluid pressure, psia (Ref. only)

Fluid temp., ${ }^{\circ} \mathrm{F}$ (Ref, only)

Average mol. wt.(Ref. only)

Viscosity, Centipoise

Fluid actual density, lb/cu ft

Compressibility factor (Ref. only)

Dew Point, ' $F$ (Ref only)

Vessel Design:

Material (CS or SS)

Diameter, $\mathrm{ft}$

Design Temp, ${ }^{\circ} \mathrm{F}$

Design Pressure, psig

Corrosion allowance, in.

Joint efficiency

Activated Carbon:

Pellet diameter, $\mathrm{mm}$.

Carbon weight, , lb

Carbon bulk density, Ib/cu ft

Calculations:

Inlet \& outlet nozzles, in.

Carbon volume, cu ft

Carbon depth, $\mathrm{ft}$

Carbon depth. in.

Design stress, psi

Shell thickness, in

Head thickness, in

Cylinder length, inches

Over all vessel height, $\mathrm{ft}$

Total steel weight, ib

Flow area, sq ft

Superficial velocity, $\mathrm{ft} / \mathrm{min}$

Superficial velocity, $\mathrm{ft} / \mathrm{sec}$

Total Flow, acfm

Mass velocity, $\mathrm{lb} / \mathrm{hr} / \mathrm{sq} \mathrm{ft}$

Empty Bed Contact Time, sec

Delta P, "WG/ft

Total Bed Delta P, "WG

Total Bed Delta P, psi

9150
14.7
167
28.966
0.0209
0.050754

50

55
10.0
200
15

1

3
11000
35

14
314
4.0
48
16700
$3 / 16$
$3 / 16$
90
10.9
3969
79
38.26
0.64
3005
117
6
0.66
2.63
0.10

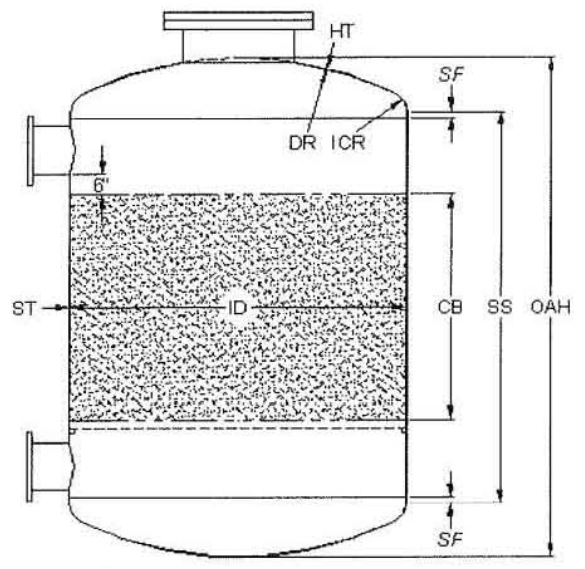

VESSEL SKETCH IS NOT TO SCALE

All Dimensions in Inches

$\mathrm{CB}=\quad 48$

$\mathrm{DR}=\quad 120$

$H T=\quad 3 / 16$

$\mathrm{ICR}=\quad 7.3$

$I D=120$

$\mathrm{OAH}=131$

$\mathrm{SF}=11 / 2$

SS $=90$

$\mathrm{ST}=\quad 3 / 16$

Beta Version 1.07 
PROJLCT RESPONSIBILITY Proposal 13238

The following project responsibility matrix is the basis for this proposal. Any changes in scope may result in price adjustments.

\begin{tabular}{|c|c|c|c|}
\hline \multirow{2}{*}{\multicolumn{2}{|c|}{ ACTIVITY }} & \multicolumn{2}{|c|}{ RESPONSIBILITY } \\
\hline & & NUCON & CLIENT \\
\hline 5.1 & \multicolumn{3}{|l|}{ ENGINEERING AND DESIGN } \\
\hline 5.1 .1 & $\begin{array}{l}\text { Verilication of design data - operational flow rates, } \\
\text { adsorbatc compositions, ctc. }\end{array}$ & & $\mathrm{x}$ \\
\hline 5.1 .2 & Equipment specifications & $\mathrm{X}$ & \\
\hline 5.1 .3 & Electrical engincering & $\mathrm{N} / \mathrm{A}$ & \\
\hline 5.1 .4 & Fire protection \& salety engincering & & $\mathrm{X}$ \\
\hline 5.1 .5 & Process enginecring & $\mathrm{X}$ & \\
\hline 5.1 .6 & Mechanical enginecring & $\mathrm{X}$ & \\
\hline 5.1 .7 & Insulation specilications & $\mathrm{X}$ & \\
\hline 5.1 .8 & Software validation (when required) & $\mathrm{N} / \mathrm{A}$ & \\
\hline 5.1 .9 & Process review of vendor drawings & $\mathrm{X}$ & \\
\hline 5.1 .10 & Dimensional revicw of vendor drawings & $\mathrm{x}$ & \\
\hline 5.1 .11 & Safety review (pre-shipment) & $\mathrm{X}$ & \\
\hline 5.1 .12 & Control system engincering & N/A & \\
\hline 5.1 .13 & Heat and material balance llow sheet & $\mathrm{N} / \mathrm{A}$ & \\
\hline 5.1 .14 & Design criteria & & $\mathrm{X}$ \\
\hline 5.1 .15 & Instrument loop diagrams & $\mathrm{N} / \mathrm{A}$ & \\
\hline 5.1 .16 & Piping and instrumentation diagram & $\mathrm{X}$ & \\
\hline 5.1 .17 & Construction drawings (civil and foundation) & & $\mathrm{X}$ \\
\hline 5.1 .18 & Demolition drawings (civil and foundation) & & $\mathrm{X}$ \\
\hline 5.1 .19 & Drawing revisions and updates & $\mathrm{X}$ & \\
\hline 5.1 .20 & System layout drawings & $\mathrm{X}$ & \\
\hline 5.1 .21 & Equipment arrangements drawings & $\mathrm{X}$ & \\
\hline
\end{tabular}




\begin{tabular}{|c|c|c|c|}
\hline \multirow{2}{*}{\multicolumn{2}{|c|}{ ACTIVITY }} & \multicolumn{2}{|c|}{ RESPONSIBILITY } \\
\hline & & NUCON & CLIENT \\
\hline 5.1 .22 & Process flow diagrams & $\mathrm{X}$ & \\
\hline 5.1 .23 & Piping schedule (line list) & $\mathrm{X}$ & \\
\hline 5.1 .24 & Instrument specilications & $\mathrm{N} / \mathrm{A}$ & \\
\hline 5.2 & PROCUREMENT & & \\
\hline 5.2 .1 & Process equipment procurement & $\mathrm{X}$ & \\
\hline 5.2 .2 & Process Safety equipment procurement & $\mathrm{N} / \mathrm{A}$ & \\
\hline 5.2 .3 & Shop inspection & $\mathrm{x}$ & \\
\hline 5.2 .4 & Receiving/storing/warchousing & $\mathrm{X}$ & \\
\hline 5.2 .5 & Expediting & $\mathrm{X}$ & \\
\hline 5.2 .6 & Fire protection equipment procurement & & $\mathrm{X}$ \\
\hline 5.2 .7 & Handling and distribution of vendor drawings & $\mathrm{X}$ & \\
\hline 5.2 .8 & Sparc parts & & $\mathrm{X}$ \\
\hline 5.2 .9 & Quality Assurance & $\mathrm{X}$ & \\
\hline 5.3 & FIELD CONSTRUCTION & & \\
\hline 5.3.1 & Sitc studies and preparation & & $\mathrm{X}$ \\
\hline 5.3.2 & Demolition & & $\mathrm{X}$ \\
\hline 5.3 .3 & Construction specilications & & $\mathrm{X}$ \\
\hline 5.3 .4 & Construction contracts & & $\mathrm{x}$ \\
\hline 5.3 .5 & Equipment/materials protection & & $\mathrm{X}$ \\
\hline 5.3 .6 & Insulation shop installed at NUCON & $\mathrm{X}$ & \\
\hline 5.3.7 & Insulation field installed on-site & & $\mathrm{X}$ \\
\hline 5.3 .8 & Field construction management and supervision & & $\mathrm{x}$ \\
\hline 5.3 .9 & Ficld inspection & & $\mathrm{X}$ \\
\hline 5.3 .10 & On-site space and services for NUCON personnel & & $\mathrm{X}$ \\
\hline
\end{tabular}




\begin{tabular}{|c|c|c|c|}
\hline \multirow{2}{*}{\multicolumn{2}{|c|}{ ACTIVITY }} & \multicolumn{2}{|c|}{ RESPONSIBILITY } \\
\hline & & NUCON & CLIENT \\
\hline 5.4 & UTILITIES & & \\
\hline 5.4 .1 & Electrical power & & $\mathrm{X}$ \\
\hline 5.4 .2 & $\mathrm{MCC}$ & & $\mathrm{X}$ \\
\hline 5.4 .3 & Stcam (Not applicable this Proposal) & & \\
\hline 5.4 .4 & Cooling water & & $\mathrm{X}$ \\
\hline 5.4 .5 & Chilled water & & $\mathrm{X}$ \\
\hline 5.4 .6 & Plant compressed air & & $\mathrm{X}$ \\
\hline 5.4 .7 & Instrument air & & $\mathrm{X}$ \\
\hline 5.4 .8 & Nitrogen & & $\mathrm{X}$ \\
\hline 5.4 .9 & Process Control Computer & $\mathrm{N} / \mathrm{A}$ & \\
\hline 5.5 & PROJECT CONTROL \& MONITORING & & \\
\hline 5.5 .1 & Project management & $\mathrm{X}$ & \\
\hline 5.5 .2 & Scheduling & $\mathrm{X}$ & \\
\hline 5.5 .3 & Progress/status reporting & $\mathrm{X}$ & \\
\hline 5.6 & OPERATIONS & & \\
\hline 5.6 .1 & Commissioning Technical Assistance & $\mathrm{X}$ & \\
\hline 5.6 .2 & Start-up Technical Assistance & $\mathrm{X}$ & \\
\hline 5.6 .3 & Pre-operational safety check & & $\mathrm{X}$ \\
\hline
\end{tabular}




\section{NUCON International, Inc.}

TELEPHONE: (614) 846.5710

FAX: (614) 431.0858

P.O. BOX 291517000 HUNTLEY ROAD

COLUMBUS, OHIO 43229 U.S.A.

Technical Data Sheet: MERSORB $^{\text {ID }}-3$ (2005/03)

\section{NUSORB ${ }^{\circledR}$ MERSORB $^{\circledR}-3$}

TYPICAL APPLICATIONS:

RAW MATERIAL:

ACTIVATION METHOD:

PARTICLE TYPE:

IMPREGNANT:

PHYSICAL PROPERTIES:

\author{
Mercury control \\ Coal \\ High Temperature Steam \\ Pellet \\ Sulfur
}

$\begin{array}{lll}\text { APPARENT DENSITY } & \text { (ASTM D2854) } & 0.55 \mathrm{~g} / \mathrm{ml} \text {, Typical } \\ \text { HARDNESS } & \text { ASTM D3802) } & 98 \% \text { Typical } \\ \text { ASH } & \text { (ASTM D2866) } & 10 \mathrm{wt} \% \text { Typical } \\ \text { MOISTURE CONTENT, as packaged } & \text { (ASTM D2867) } & 5 \% \text { Maximum } \\ \text { PARTICLE SIZE, } & & 3 \mathrm{~mm} \text { Diameter } \\ \text { CARBON TETRACHLORIDE ACTIVITY } & \text { (ASTM D3467) } & 60 \% \text { Minimum } \\ \text { SULFUR CONTENT } & & 13 \% \text { Typical }\end{array}$

Additional ASTM or custom testing available on request

PACKAGING: Square fiber drums (150 pounds) or "tote bags"(1,000 pounds)

Information herein is accurate to the best of our knowledge. User should determine the suitability of the product for the intended use; liability consists of replacing product. NUCON INTERNATIONAL, INC., does not suggest violation of any existing patents or give permission to practice any patented invention without a license.

For additional information contact:

NUCON International, Inc, 7000 Huntley Road, Columbus, OH 43229, USA

Telephone: 614-846-5710 FAX: 614-431-0858 www.nucon-int.com 
Pressure Drop Curve for All NUSORB ${ }^{\circledR}$ Grades of $1.5 \mathrm{~mm}, 3 \mathrm{~mm}$ and $4 \mathrm{~mm}$ Diameter Pelleted Carbons

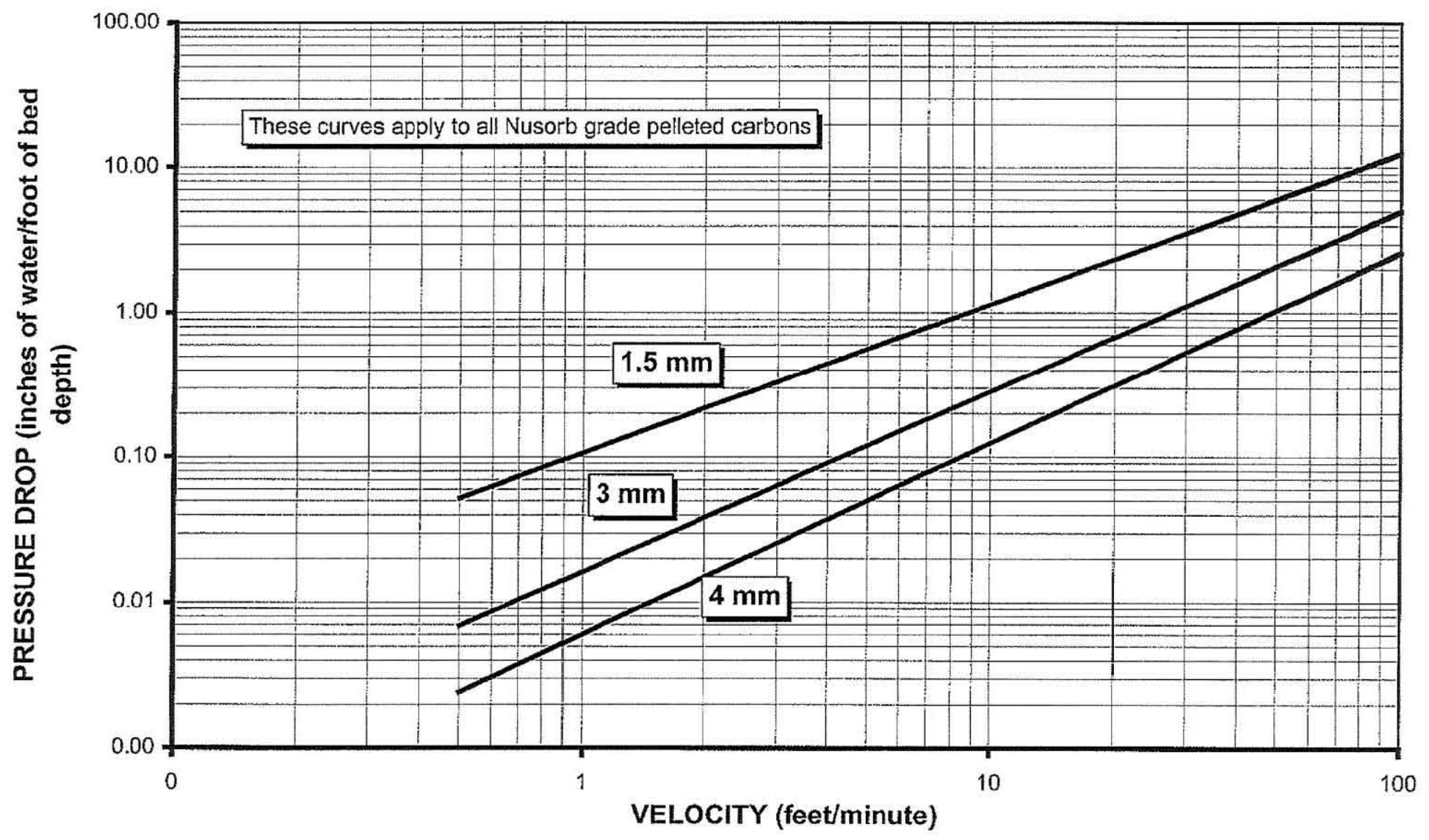


24590-WTP-RPT-ENV-01-005, Rev. 0 Best Available Control Technology Analysis for Toxic Air Pollutants for the WTP

Table B-4. TBACT Control Technology Cost Estimate Activated Carbon Adsorber

Stream $\mathbf{S 1 2 0}$

HLW Melter Offgas Unabated

\begin{tabular}{|c|c|c|c|}
\hline Cost Item & Basis & & Example Cost \\
\hline \multicolumn{4}{|l|}{ Direct Costs } \\
\hline \multicolumn{4}{|l|}{ Purchased Equipment Costs } \\
\hline Equipment & & & $\$ 1,977,962.00$ \\
\hline Required Ancillary Equipment ( $\$ 10 / \mathrm{cfm})$ & & & $\$ 23,000.00$ \\
\hline Instrumentation and Control & $15 \%$ of Equipment & & $\$ 296,694.30$ \\
\hline Freight & $5 \%$ of Equipment & & $\$ 98,898.10$ \\
\hline Subtotal Purchased Equipment Costs (PEC) & & & $\$ 2,396,554.40$ \\
\hline \multicolumn{4}{|l|}{ Direct Installation Costs } \\
\hline Foundations \& Supports & $8 \%$ of Subtotal PEC & & $\$ 191,724.35$ \\
\hline Handling \& Erection & $14 \%$ of Subtotal PEC & & $\$ 335,517.62$ \\
\hline Electrical & $4 \%$ of Subtotal PEC & & $\$ 95,862.18$ \\
\hline Piping and Duct Work & $4 \%$ of Subtotal PEC & & $\$ 95,862.18$ \\
\hline Insulation for Piping \& Equipment & $4 \%$ of Subtotal PEC & & $\$ 95,862.18$ \\
\hline Painting & $2 \%$ of Subtotal PEC & & $\$ 47.931 .09$ \\
\hline Subtotal Installation Costs (IC) & & & $\$ 862,759.58$ \\
\hline Site Preparation & Equipment Specific & & $\$ 20,000.00$ \\
\hline Building Costs & see cost factors below & equipment size & \\
\hline C5 Location per square foot & $\$ 1,388 / \mathrm{sf}$ & $52 \mathrm{sf}$ & $\$ 72.176 .00$ \\
\hline Subtotal - Building (per highest applicable cost area) & Equipment Specific & & $\$ 72,176.00$ \\
\hline Total Direct Cost & & & $\$ 3,351,489.98$ \\
\hline \multicolumn{4}{|l|}{ Indirect Costs (Installation) } \\
\hline Engineering & $10 \%$ of PEC & & $\$ 239,655.44$ \\
\hline Construction and Field Expenses & $5 \%$ of PEC & & $\$ 119,827.72$ \\
\hline Start-up & $10 \%$ of PEC & & $\$ 239,655.44$ \\
\hline Performance Tests & $1 \%$ of PEC & & $\$ 23,965.54$ \\
\hline Contingencies & $15 \%$ of $\mathrm{PEC}$ & & $\$ 359,483.16$ \\
\hline Total Indirect Costs & & & $\$ 982,587.30$ \\
\hline Total Capital Costs (TCC) & & & $\$ 4,334,077.29$ \\
\hline
\end{tabular}

Source: Modified from EPA Handbook Control Technologies for Hazardous Air Pollutants (June 1991). 
24590-WTP-RPT-ENV-01-005, Rev. 0 Best Available Control Technology Analysis for

Toxic Air Pollutants for the WTP

Table B-4. TBACT Control Technology Cost Estimate Activated Carbon Adsorber

Stream S120

HLW Melter Offgas Unabated

\begin{tabular}{|c|c|c|c|}
\hline Cost Item & Factor & & Example Cost \\
\hline \multicolumn{4}{|l|}{ Direct Annual Costs } \\
\hline \multicolumn{4}{|l|}{ Utilities } \\
\hline Electricity & $\$ 0.08 / \mathrm{kWhr}$ & & $\$ 0.00$ \\
\hline Steam & $\$ 6.00 / 1000 \mathrm{lb}$ & & $\$ 0.00$ \\
\hline Water & $\$ 0.25 / 1000$ gal. & & $\$ 0.00$ \\
\hline Materials/Chemicals & Process Specific & & $\$ 0.00$ \\
\hline \multicolumn{4}{|l|}{ Operating Expenses } \\
\hline Operator & $\$ 20 / \mathrm{Hr}$ & $52 \mathrm{hr}$ & $\$ 1,040.00$ \\
\hline Supervisor & $15 \%$ of Operator & & $\$ 156.00$ \\
\hline Secondary Waste T\&D & $184 \mathrm{cf} / \mathrm{yr} \times \$ 129.24 / \mathrm{cf}$ & & $\$ 23,780.16$ \\
\hline \multicolumn{4}{|l|}{ Maintenance } \\
\hline Labor & $\$ 17 / \mathrm{Hr}$ & $72 \mathrm{hr} / 2 \mathrm{yr}$ & $\$ 612.00$ \\
\hline Materials & $5,520 \mathrm{lbs} / \mathrm{yr}$ & & $\$ 5,520.00$ \\
\hline \multicolumn{4}{|l|}{ Indirect Annual Costs } \\
\hline Overhead & $6 \%$ of Labor Costs & & $\$ 1,084.80$ \\
\hline Administrative & $2 \%$ of TCC & & $\$ 86,681.55$ \\
\hline Insurance & $1 \%$ of TCC & & $\$ 43,340.77$ \\
\hline Total Annual Costs (TAC) & & & $\$ 162,215.28$ \\
\hline Rate of Return on Capital Investment & $10.00 \%$ & & \\
\hline Service Life (years) & 40 & & \\
\hline Capital Recovery Factor & 0.1023 & & \\
\hline Annualized Capital Investment (ACI) & & & $\$ 443,200.21$ \\
\hline Grand Total Annualized Costs & $\mathrm{ACI}+\mathrm{TAC}$ & & $\$ 605,415.48$ \\
\hline
\end{tabular}

Source: Modified from EPA Handbook Control Technologies for Hazardous Air Pollutants (June 1991).

Page B-59 
24590-WTP-RPT-ENV-01-005, ReV. 0 Best Available Control Technology Analysis for Toxic Air Pollutants for the WTP

Table B-4. TBACT Control Technology Cost Estimate Activated Carbon Adsorber

Stream S74/S1

LPP LAW Melter Feed Evaporator

\begin{tabular}{|c|c|c|c|}
\hline Cost Item & Factor & & Example Cost \\
\hline \multicolumn{4}{|l|}{ Direct Annual Costs } \\
\hline \multicolumn{4}{|l|}{ Utilities } \\
\hline Electricity & $\$ 0.08 / \mathrm{kWhr}$ & & $\$ 0.00$ \\
\hline Steam & $\$ 6.00 / 1000 \mathrm{lb}$ & & $\$ 0.00$ \\
\hline Water & $\$ 0.25 / 1000$ gal. & & $\$ 0.00$ \\
\hline Materials/Chemicals & Process Specific & & $\$ 0.00$ \\
\hline \multicolumn{4}{|l|}{ Operating Expenses } \\
\hline Operator & $\$ 20 / \mathrm{Hr}$ & $52 \mathrm{hr}$ & $\$ 1,040.00$ \\
\hline Supervisor & $15 \%$ of Operator & & $\$ 156.00$ \\
\hline Secondary Waste T\&D & $296 \mathrm{cf} / \mathrm{yr} \times \$ 129.24 / \mathrm{cf}$ & & $\$ 38,255.04$ \\
\hline \multicolumn{4}{|l|}{ Maintenance } \\
\hline Labor & $\$ 17 / \mathrm{Hr}$ & $72 \mathrm{hr} / 2 \mathrm{yr}$ & $\$ 612.00$ \\
\hline Materials & $5,520 \mathrm{lbs} / \mathrm{yr}$ & & $\$ 10,000.00$ \\
\hline \multicolumn{4}{|l|}{ Indirect Annual Costs } \\
\hline Overhead & $6 \%$ of Labor Costs & & $\$ 1,084.80$ \\
\hline Administrative & $2 \%$ of TCC & & $\$ 115,524.16$ \\
\hline Insurance & $1 \%$ of TCC & & $\$ 57,762.08$ \\
\hline Total Annual Costs (TAC) & & & $\$ 224,434.08$ \\
\hline Rate of Return on Capital Investment & $10.00 \%$ & & \\
\hline Service Life (years) & 40 & & \\
\hline Capital Recovery Factor & 0.1023 & & \\
\hline Annualized Capital Investment (ACI) & & & $\$ 590,671.66$ \\
\hline Grand Total Annualized Costs & $\mathbf{A C I}+\mathbf{T A C}$ & & $\$ 815,105.74$ \\
\hline
\end{tabular}

Source: Modified from EPA Handbook Control Technologies for Hazardous Air Pollutants (June 1991). 
24590-WTP-RPT-ENV-01-005, Rev. 0 Best Available Control Technology Analysis for Toxic Air Pollutants for the WTP

Table B-4. TBACT Control Technology Cost Estimate Activated Carbon Adsorber

Stream S41Z

PT Vessel Vents Unabated

\begin{tabular}{|c|c|c|c|}
\hline Cost Item & Basis & & Example Cost \\
\hline \multicolumn{4}{|l|}{ Direct Costs } \\
\hline \multicolumn{4}{|l|}{ Purchased Equipment Costs } \\
\hline Equipment & & & $\$ 2,128,949.00$ \\
\hline Required Ancillary Equipment (\$10/cfm) & & & $\$ 26,000.00$ \\
\hline Instrumentation and Control & $15 \%$ of Equipment & & $\$ 319,342.35$ \\
\hline Freight & $5 \%$ of Equipment & & $\$ 106,447.45$ \\
\hline Subtotal Purchased Equipment Costs (PEC) & & & $\$ 2,580,738.80$ \\
\hline \multicolumn{4}{|l|}{ Direct Installation Costs } \\
\hline Foundations \& Supports & $8 \%$ of Subtotal PEC & & $\$ 206,459.10$ \\
\hline Handling \& Erection & $14 \%$ of Subtotal PEC & & $\$ 361,303.43$ \\
\hline Electrical & $4 \%$ of Subtotal PEC & & $\$ 103,229.55$ \\
\hline Piping and Duct Work & $4 \%$ of Subtotal PEC & & $\$ 103,229.55$ \\
\hline Insulation for Piping \& Equipment & $4 \%$ of Subtotal PEC & & $\$ 103,229.55$ \\
\hline Painting & $2 \%$ of Subtotal PEC & & $\$ 51,614.78$ \\
\hline Subtotal Installation Costs (IC) & & & $\$ 929,065.97$ \\
\hline Site Preparation & Equipment Specific & & $\$ 20,000.00$ \\
\hline Building Costs & see cost factors below & equipment size & \\
\hline C5 Location per square foot & $\$ 1,388 / \mathrm{sf}$ & $52 \mathrm{sf}$ & $\$ 72.176 .00$ \\
\hline Subtotal - Building (per highest applicable cost area) & Equipment Specific & & $\$ 72,176.00$ \\
\hline Total Direct Cost & & & $\$ 3,601,980.77$ \\
\hline \multicolumn{4}{|l|}{ Indirect Costs (Installation) } \\
\hline Engineering & $10 \%$ of PEC & & $\$ 258,073.88$ \\
\hline Construction and Field Expenses & $5 \%$ of PEC & & $\$ 129,036.94$ \\
\hline Start-up & $10 \%$ of PEC & & $\$ 258,073.88$ \\
\hline Performance Tests & $1 \%$ of PEC & & $\$ 25,807.39$ \\
\hline Contingencies & $15 \%$ of $\mathrm{PEC}$ & & $\$ 387,110.82$ \\
\hline Total Indirect Costs & & & $\$ 1,058,102.91$ \\
\hline Total Capital Costs (TCC) & & & $\$ 4,660,083.68$ \\
\hline
\end{tabular}

Source: Modified from EPA Handbook Control Technologies for Hazardous Air Pollutants (June 1991).

Page B-140 
24590-WTP-RPT-ENV-01-005, Rev. 0 Best Available Control Technology Analysis for Toxic Air Pollutants for the WTP

Table B-4. TBACT Control Technology Cost Estimate Activated Carbon Adsorber

Stream $\mathrm{S412}$

PT Vessel Vents Unabated

\begin{tabular}{|c|c|c|c|}
\hline Cost Item & Factor & & Example Cost \\
\hline \multicolumn{4}{|l|}{ Direct Annual Costs } \\
\hline \multicolumn{4}{|l|}{ Utilities } \\
\hline Electricity & $\$ 0.08 / \mathrm{kWhr}$ & & $\$ 0.00$ \\
\hline Steam & $\$ 6.00 / 1000 \mathrm{lb}$ & & $\$ 0.00$ \\
\hline Water & $\$ 0.25 / 1000 \mathrm{gal}$. & & $\$ 0.00$ \\
\hline Materials/Chemicals & Process Specific & & $\$ 0.00$ \\
\hline \multicolumn{4}{|l|}{ Operating Expenses } \\
\hline Operator & $\$ 20 / \mathrm{Hr}$ & $52 \mathrm{hr}$ & $\$ 1,040.00$ \\
\hline Supervisor & $15 \%$ of Operator & & $\$ 156.00$ \\
\hline Secondary Waste T\&D & $208 \mathrm{cf} / \mathrm{yr} \times \$ 129.24 / \mathrm{cf}$ & & $\$ 26,881.92$ \\
\hline \multicolumn{4}{|l|}{ Maintenance } \\
\hline Labor & $\$ 17 / \mathrm{Hr}$ & $72 \mathrm{hr} / 2 \mathrm{yr}$ & $\$ 612.00$ \\
\hline Materials & $6240 \mathrm{lbs} / \mathrm{yr}$ & & $\$ 6,240.00$ \\
\hline \multicolumn{4}{|l|}{ Indirect Annual Costs } \\
\hline Overhcad & $6 \%$ of Labor Costs & & $\$ 1,084.80$ \\
\hline Administrative & $2 \%$ of TCC & & $\$ 93,201.67$ \\
\hline Insurance & $1 \%$ of TCC & & $\$ 46,600.84$ \\
\hline Total Annual Costs (TAC) & & & $\$ 175,817.23$ \\
\hline Rate of Return on Capital Investment & $10.00 \%$ & & \\
\hline Service Life (years) & 40 & & \\
\hline Capital Recovery Factor & 0.1023 & & \\
\hline Annualized Capital Investment $(\mathrm{ACl})$ & & & $\$ 476,537.43$ \\
\hline Grand Total Annualized Costs & $\mathbf{A C I}+\mathrm{TAC}$ & & $\$ 652,354.66$ \\
\hline
\end{tabular}

Source: Modified from EPA Handbook Control Technologies for Hazardous Air Pollutants (June 1991) 


\begin{tabular}{|c|c|c|c|c|c|c|c|c|}
\hline \multicolumn{9}{|c|}{ TOTAL ANINUAL. COST SPREADSHEET PROGRAM-CAREON ADSORBERS $[1]$} \\
\hline & & & & & & & & \\
\hline \multicolumn{9}{|c|}{ COST BASE DATE Third Quarter 1989 [2] } \\
\hline & & & & & & & & \\
\hline \multicolumn{3}{|c|}{ VAPCCI (Third Cuanter 2003-PRELIMINARY): [3] } & & 113.8 & & & & \\
\hline & & & & & & & & \\
\hline \multicolumn{2}{|c|}{ INPUT PARAMETERS } & & & & & & & \\
\hline \multicolumn{2}{|c|}{ - Iniet stream flowrate (actni): } & & & 4.985 & & & & \\
\hline \multicolumn{2}{|c|}{ - Inlel stream temperature (OF): } & & & 220 & & & & \\
\hline \multicolumn{2}{|c|}{ - Inlet stream pressura (aim): } & & & 1 & & & & \\
\hline \multicolumn{2}{|c|}{ - VOC to be condensed: } & & Mix of vola & tile organics (primarily) & & & & \\
\hline \multicolumn{2}{|c|}{$\because$ Inlel VOC fowrate flodin? } & & & 0.22 & Annual average & & & \\
\hline \multirow{2}{*}{\multicolumn{2}{|c|}{$\begin{array}{l}\text { - VOC molecular weight (bibib-mcte) } \\
\text { - VOC inlet volume traction: }\end{array}$}} & & & 80.00 & & & & \\
\hline & & & & $3.9 E-06$ & & & & \\
\hline$\because$ VOC iniel concentratic & (pprnv) & & & 3.9 & & & & \\
\hline$\because$ VOC iniel partial pres: & re (psia): & & & 0.000057 & & & & \\
\hline - Required VOC remov & (fraction) & & & 0.98 & & & & \\
\hline$\because$ Freundticn isotherm $\mathrm{e}$ & ation constants for $V$ & OC isee Table I be & low): & & & & & \\
\hline & VOC number (enter & or Table 1 \# or zero, & if no data): & 0 & & & & \\
\hline & & & $k$ & 0.000 & & & & \\
\hline & & & M: & 0.000 & & & & \\
\hline - Yaws isotherm equati & constants (see Table & le 2 below): & & & & & & \\
\hline & VOC number (enter & or Table 2 for zero, & (no data): & 0 & : & & & \\
\hline & & & & 0.00000 & & & & \\
\hline & & & & 0.00000 & & & & \\
\hline & & & & 0.00000 & & & & \\
\hline - Adsorption time (hr): & & & & 8.0 & & & & \\
\hline - Desorption lime (hr) & & & & 4.0 & & & & \\
\hline - Number of adsorbing & ssels: & & & 1 & & & & \\
\hline - Superficial carbon bec & glocity (ivmin). & & & 75 & & & & \\
\hline - Carbon price $(5 / \mathrm{ib})$ : & & & & 2.00 & & & & \\
\hline - Material of constructio & see list below): $[4]$ & & & 1.3 & & & & \\
\hline & & & & & & & & \\
\hline & & DESIGN PARAME & TERS: & & & & & \\
\hline - Carbon equibrium ca & Clty-Freundich (I0 V & VOCat carb) & & 0.0000 & Void for this pro & ject. & & \\
\hline 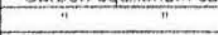 & - - Yaws et a & al $" 1-7$ & & 0.0000 & Void for this pro & ject. & & \\
\hline - Carbon working capae & (to VOCllb carioon): & & & 0.3241 & Linked to "Carb & on Capacity Est & timate" sheet. & \\
\hline - Number of desorbing & ssets. & & & 1. & & & $i$ & \\
\hline - Total number of vesse & & & & 2 & & & & \\
\hline - Carbon requirement, & al (ib): & & & 11 & $=7$ & & & \\
\hline - Carbon requirement p & vessei (1b) & & & 5 & $-\quad$ & & & \\
\hline . Gas flowrate per vess & (acim): & & & 4988 & & & & \\
\hline - Adsorber vessel diarn & er (if): & & & 9.202 & 1 & & & \\
\hline - Adsorber vessel lengt & & & & 4.003 & 77 & & & \\
\hline - Adscrber vessel surfa & area (It2) & & & 248.73 & 11 & & & \\
\hline - Carbon bed thickness & & & & 0.003 & & & & \\
\hline - Carbon bed pressure & $p p$ (in wac) $15 i$ & & & 0.009 & + & & & \\
\hline & & & & & & & & \\
\hline & & CAPITAL COSTS & & & & Accessories & & \\
\hline Equipment Costs (\$): & & & & & Item & Cost & Comments & \\
\hline - Adsorber vassels & & & & 51,501 & $\begin{array}{l}\mathrm{HX} \text { for cooling } \\
\text { and dehumid }\end{array}$ & 178,000 & $\begin{array}{l}\text { Hudson } \\
\text { Products } \\
\text { software }\end{array}$ & \\
\hline - Caroon & & & & 22 & $\begin{array}{l}\text { HX fan, duct, } \\
\text { damper, and } \\
\text { temp control }\end{array}$ & & & \\
\hline - Other equipment (con & nser, decantes, etc, & & & 58,636 & $\begin{array}{l}\text { Heating coil } \\
\text { with temp } \\
\text { control }\end{array}$ & & & \\
\hline Ictat equinment cost (\$) & ase. & & & 96,627 & & & & \\
\hline -escalate & & & & 121,948 & & & & \\
\hline Puichased Equipment C & $(\$)$. & & & 131,704 & & & T. & \\
\hline Accessories & & & & 178,000 & Total & 178,000 & & \\
\hline PEC, with Accossories & & & & 309,704 & & & & \\
\hline No of Tanks over life of & & & & 1 & & & & \\
\hline Total Capital investment & & & & $1,456,281$ & & & & \\
\hline $4 \quad-1$ & (Siacim). & & & 292.0 & & & & \\
\hline & & & & & & & & \\
\hline & & ANINUAL COST IN & DUTS & & & & & \\
\hline Operating factor (hitive): & & & 8760 & & & & & \\
\hline Operating labor rate i $\$ \mathrm{~h}$ & & & 51.58 & & & & & \\
\hline Maintenance labor rate & & & 50.78 & & & & & \\
\hline Operating labor factor (h & & & 0.0 & & & & & \\
\hline Maintenance isvor factor & arish): & & 0.5 & & & & & \\
\hline Electricity price (\$ $/ \mathrm{k}^{\prime} \mathrm{W} / \mathrm{hr}$ & & & 0.08 & & & & & \\
\hline
\end{tabular}




\begin{tabular}{|c|c|c|c|c|c|c|c|c|}
\hline Recovered voc value (S & & & 0.0000 & & & & & \\
\hline Steam price $(S / 1000 \mathrm{lb})$ & & & 600 & & & & & \\
\hline Cooling water price $(\$ / 10$ & ogal: & & 0.20 & & & & & \\
\hline Carbon replacement labo & $(s+b)$ & & 0.05 & & & & & \\
\hline Overnead rate (fraction): & & & 0.6 & & & & & \\
\hline Annual interest rate (frac & & & 007 & & & & & \\
\hline Control system life (year & & & 11 & & & & & \\
\hline Capital recovery factor is & steni) & & 0.1334 & & & & & \\
\hline Carbon life (years): & & & 5. & & & & & \\
\hline Capital recovery factor ic & thonj & & 0.2439 & & & & & \\
\hline Taxes, insurauce, admin & actor & & 0.04 & & & & & \\
\hline & & & & & & & & \\
\hline & & ANNUUAL COS & STS: & & & & & \\
\hline Item & & & $\operatorname{Cost}($ Siyr) & Wit Factor & W.F.(cond.) & & & \\
\hline-1 & 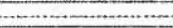 & 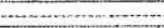 & $(-1-1-1-1-1$ & $\ldots \ldots \ldots$ & 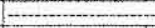 & & & \\
\hline Operating lathor & & & 0 & 0.000 & $\ldots$ & & & \\
\hline Supervisory labor & & & 0 & 0.000 & $\cdots$ & & & \\
\hline Ma:ntenance labor & & & 27,802 & 0.081 & $\cdots$ & & & \\
\hline Maintenance materials & & & 27,802 & 0.081 & $\ldots .$. & & & \\
\hline Electricity & & & 7 & 0.000 & $\ldots$ & & & \\
\hline Steam & & & 40 & 0.000 & $\ldots .$. & & & \\
\hline Cooling watei & & & 5 & 0.000 & $\cdots \cdot$. & & & \\
\hline Carbon replacement & & & 6 & 0.000 & $\cdots$ & & & \\
\hline Overnead & & & 33,362 & 0.098 & 0.261 & & & \\
\hline Taxes, insurance, admini & rative & & 58,251 & 0.171 & - & & & \\
\hline Capitul recovery & & & 194,202 & 0.569 & 0.739 & & & \\
\hline 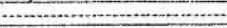 & - & 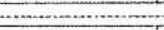 & $+\ldots$ & $-+-1+1-1$ & $-1+1$ & & & \\
\hline Total Annual Cost (witho & credits) & & 341,478 & 1.000 & 1.000 & & & \\
\hline Recovery credits & & & 0 & & & & & \\
\hline Totai Annual Cost (with o & dits; & & 341,478 & & & & & \\
\hline$" \quad$ " $\quad$ (\$ & (illion acf) & & 130.25 & & & & & \\
\hline & & & & & & & & \\
\hline Total Unabatect Orpanic & P Emissions, tons & & 0.96 & & & & & \\
\hline Emission Control Éficien & $y=$ & & 0.98 & & & & & \\
\hline Total Abated Organic TA & Emissions, tons $=$ & & 0.94 & & & & & \\
\hline Cost-Effectiveness. Silon & & & 362,965 & & & & & \\
\hline & & & & & & & & \\
\hline & & & & & & & & \\
\hline Notes & & & & & & & & \\
\hline$\ldots \ldots$ & & & & & & & & \\
\hline [1] This program has bee & based on data and & rocedures in Chap & $\operatorname{tet} 4$ & & & & & \\
\hline of the OAQPS CONTRO & COST MANUAL $\angle 5 I$ & Edition) & & & & & & \\
\hline & & & & & & & & \\
\hline [2] Base equipment costs & eflect this oate & & & & & & & \\
\hline & & & & & & & & \\
\hline [3] VAPCCI $=$ Vatavuk Ai & Pollution Control Co & tincex ffor carben & & & & & & \\
\hline adsoribers) corresponding & - year and quarter : & lown Base equipt & ment & & & & & \\
\hline cost, purchased equipme & cost, and total capi & al invesiment have & been & & & & & \\
\hline escalated to this date via & Ie $V A P C C I$ and con & ol equipment vend & dor data & & & & & \\
\hline & & & & & & & & \\
\hline (4) Enter one of the follow & g: carbon steel- 1 . & 316 stainless steel & & & & & & \\
\hline 1.3 : Carpenter $20 / C B-3$ & 1.9.' Monel-400-'2 & 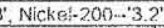 & & & & & & \\
\hline titanium -4.5 & & & & & & & & \\
\hline & & & & & & & & \\
\hline [5] This is the carbon bed & ressure drop ONLY & There will be add & ditional pressure & $\mathrm{rep}$ & & & & \\
\hline through the ductwork. F & estimating ductwor & pressure losses, s & see Chapter 10 & & & & & \\
\hline of the OAQPS CONTRO & COST MANUAL (5t) & edition) & & & & & & \\
\hline & & & & & & & & \\
\hline & Table 1. Freundlic & Constants for Sel & $a c$ & is [6] & & & & \\
\hline & & & & & & Correlation $R$ & ange (psia) & \\
\hline VOC name & & VOC number & K & $M$ & Temperature (F & Minimum & Maximum & \\
\hline 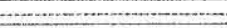 & - & $\cdots+$ & …… & 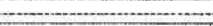 & (1) & $+1+1+n$ & $\ldots$ & \\
\hline Benzene & & 1001 & 0.597 & 0.176 & 77 & 0.0001 & 0.05 & \\
\hline Chlorobenzene & & 1002 & 1.05 & 0.188 & 77 & 0.0001 & 0.01 & \\
\hline Cyclohexane & & 1003 & 0.508 & 0.210 & 100 & 0.0001 & 0.05 & \\
\hline Dichroroethane & & 1004 & 0.976 & 0.281 & 77 & 0.0001 & 0.04 & \\
\hline Phend & & 1005 & 0.855 & 0.153 & 104 & 0.0001 & 0.03 & \\
\hline Trichloroethane & & 1006 & 1.06 & 0.161 & 77 & 0.0001 & 0.04 & \\
\hline Vinyl chloride & & 1007 & 0.200 & 0.477 & 100 & 0.0001 & 0.05 & \\
\hline m-xylene low-pressure r & age) & 1008 & 0.708 & 0.113 & 77 & 0.0001 & 0.001 & \\
\hline mi-Xyiene ihigh-pressure & inge) & 1009 & 0.527 & 0.0703 & 77 & 0.001 & 0.05 & \\
\hline Acrylonitrile & & 1010 & 0.935 & 0.424 & 100 & 0.0001 & 0.015 & \\
\hline Acetone & & 1011 & 0.412 & 0.389 & 100 & 0.0001 & 0.05 & \\
\hline Toluene & & 1012 & 0.551 ! & 0.110 & 77 & 0.0001 & 0.05 & \\
\hline (b) These conetants fit th & 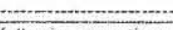 & & & 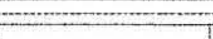 & 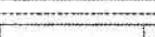 & & A......... & \\
\hline [6) These constants fit th & following equation: & & & & & & & \\
\hline & $Q=K(P)^{\wedge} M$ & & & & & & & \\
\hline
\end{tabular}




\section{Appendix 1-D}

Wet Caustic Scrubber Cost Estimate 
24590-WTP-RPT-ENV-01-005, Rev. 0 Best Available Control Technology Analysis for Toxic Air Pollutants for the WTP

Table B-4. TBACT Control Technology Cost Estimate Wet Caustic Scrubber

Stream S9v/S17

PT LAW Evaporator Offgas Unabated

\begin{tabular}{|c|c|c|c|}
\hline Cost Item & Basis & & Example Cost \\
\hline \multicolumn{4}{|l|}{ Direct Costs } \\
\hline \multicolumn{4}{|l|}{ Purchased Equipment Costs } \\
\hline Equipment & & & $\$ 552,000.00$ \\
\hline Required Ancillary Equipment & & & $\$ 0.00$ \\
\hline Instrumentation and Control & $15 \%$ of Equipment & & $\$ 82,800.00$ \\
\hline Freight & $5 \%$ of Equipment & & $\$ 27,600,00$ \\
\hline Subtotal Purchased Equipment Costs (PEC) & & & $\$ 662,400,00$ \\
\hline \multicolumn{4}{|l|}{ Direct Installation Costs } \\
\hline Foundations \& Supports & $8 \%$ of Subtotal PEC & & $\$ 52,992.00$ \\
\hline Handling \& Erection & $14 \%$ of Subtotal PEC & & $\$ 92,736.00$ \\
\hline Electrical & $4 \%$ of Subtotal PEC & & $\$ 26,496.00$ \\
\hline Piping and Duct Work & $4 \%$ of Subtotal PEC & & $\$ 26,496.00$ \\
\hline Insulation for Piping \& Equipment & $4 \%$ of Subtotal PEC & & $\$ 26,496.00$ \\
\hline Painting & $2 \%$ of Subtotal PEC & & $\$ 13,248,00$ \\
\hline Subtotal Installation Costs (IC) & & & $\$ 238,464.00$ \\
\hline $\begin{array}{l}\text { Site Preparation } \\
\text { Building Costs }\end{array}$ & $\begin{array}{l}\text { Equipment Specific } \\
\text { see cost factors below }\end{array}$ & equipment size & $\$ 20,000.00$ \\
\hline C5 Location per square foot & $\$ 1,388 / \mathrm{sf}$ & Is $\mathrm{sf}$ & $\$ 24,984.00$ \\
\hline Subtotal - Building (per highest applicable cost area) & Equipment Specific & & $\$ 24,984.00$ \\
\hline Total Direct Cost & & & $\$ 945,848.00$ \\
\hline \multicolumn{4}{|l|}{ Indirect Costs (Installation) } \\
\hline Engineering & $10 \%$ of $\mathrm{PEC}$ & & $\$ 66,240.00$ \\
\hline Construction and Field Expenses & $5 \%$ of PEC & & $\$ 33,120.00$ \\
\hline Start-up & $10 \%$ of PEC & & $\$ 66,240.00$ \\
\hline Performance Tests & $1 \%$ of PEC & & $\$ 6,624.00$ \\
\hline Contingencics & $15 \%$ of PEC & & $\$ 99,360.00$ \\
\hline Total Indirect Costs & & & $\$ 271,584.00$ \\
\hline Total Capital Costs (TCC) & & & $\$ 1,217,432.00$ \\
\hline
\end{tabular}

Source: Modified from EPA Handbook Control Technologies for Hazardous Air Pollutants (June 1991).

Page B-284 
24590-WTP-RPT-ENV-01-005, Rev, 0 Best Available Control Technology Analysis for Toxic Air Pollutants for the WTP

Table B-4. TBACT Control Technology Cost Estimate Wet Caustic Scrubber

\begin{tabular}{|c|c|c|}
\hline Cost Item & Factor & Example Cost \\
\hline \multicolumn{3}{|l|}{ Direct Annual Costs } \\
\hline Electricity & $\$ 0.08 / \mathrm{kWhr}$ & $\$ 0.00$ \\
\hline Steam & $\$ 6.00 / 1000 \mathrm{lb}$ & so.00 \\
\hline Water & $\$ 0.25 / 1000 \mathrm{gal}$ & $\$ 5,000,00$ \\
\hline Materials/Chemicals & Process Specific & $\$ 25,000.00$ \\
\hline \multicolumn{3}{|l|}{ Operating Expenses } \\
\hline Operator & $\$ 20 / \mathrm{Hr}$ & $\$ 1,040.00$ \\
\hline Supervisor & $15 \%$ of Operator & $\$ 156.00$ \\
\hline Secondary Waste T\&D & Process Specific & $\$ 0.00$ \\
\hline \multicolumn{3}{|l|}{ Maintenance } \\
\hline Labor & $24 \mathrm{hr} / 2 \mathrm{yr}$ & $\$ 204.00$ \\
\hline Materials & $100 \%$ of Maintenance Labor & $\$ 204.00$ \\
\hline \multicolumn{3}{|l|}{ Indirect Annual Costs } \\
\hline Overhead & $6 \%$ of Labor Costs & $\$ 840.00$ \\
\hline Administrative & $2 \%$ of TCC & $\$ 24,348.64$ \\
\hline Insurance & $1 \%$ of TCC & $\$ 12,174.32$ \\
\hline Total Annual Costs (TAC) & & $\$ 68,966.96$ \\
\hline Rate of Return on Capital Investment & $10.00 \%$ & \\
\hline Service Life (years) & 40 & \\
\hline Capital Recovery Factor & 0.1023 & \\
\hline Annualized Capital Investment (ACl) & & S124,493.88 \\
\hline Grand Total Annualized Costs & $\mathrm{ACI}+\mathrm{TAC}$ & $\$ 193,460.84$ \\
\hline
\end{tabular}

Source: Modified from EPA Handbook Control Technologies for Hazardous Air Pollutants (June 1991). 
24590-WTP-RPT-ENV-01-005, Rev. 0 Best Available Control Technology Analysis for Toxic Air Pollutants for the WTP

Table B-4. TBACT Control Technology Cost Estimate Wet Caustic Scrubber

Stream S41

PT PJM/RFD Offgas Unabated

\begin{tabular}{|c|c|c|c|}
\hline Cost Item & Basis & & Example Cost \\
\hline \multicolumn{4}{|l|}{ Direct Costs } \\
\hline \multicolumn{4}{|l|}{ Purchased Equipment Costs } \\
\hline Equipment & & & $\$ 1,224,000.00$ \\
\hline \multicolumn{3}{|c|}{ Required Ancillary Equipment (heat xers, quench, etc.) } & $\$ 0.00$ \\
\hline Instrumentation and Control & $15 \%$ of Equipment & & $\$ 183,600,00$ \\
\hline Freight & $5 \%$ of Equipment & & $\$ 61,-200.00$ \\
\hline Subtotal Purchased Equipment Costs (PEC) & & & $\$ 1,468,800.00$ \\
\hline \multicolumn{4}{|l|}{ Direct Installation Costs } \\
\hline Foundations \& Supports & $8 \%$ of Subtotal PEC & & $\$ 117,504.00$ \\
\hline Handling \& Erection & $14 \%$ of Subtotal PEC & & $\$ 205,632.00$ \\
\hline Electrical & $4 \%$ of Subtotal PEC & & $\$ 58,752.00$ \\
\hline Piping and Duct Work & $4 \%$ of Subtotal PEC & & $\$ 58,752.00$ \\
\hline Insulation for Piping \& Equipment & $4 \%$ of Subtotal PEC & & $\$ 58,752.00$ \\
\hline Painting & $2 \%$ of Subtotal PEC & & $\$ 29,376,00$ \\
\hline \multicolumn{3}{|l|}{ Subtotal Installation Costs (IC) } & $\$ 528,768.00$ \\
\hline \multirow{2}{*}{$\begin{array}{l}\text { Site Preparation } \\
\text { Building Costs } \\
\quad \text { C } 5 \text { Location per square foot }\end{array}$} & \multirow{2}{*}{$\begin{array}{l}\text { Equipment Specific } \\
\text { see cost factors below } \\
\$ 1,388 / \text { sf }\end{array}$} & \multirow{2}{*}{$\begin{array}{l}\text { equipment size } \\
36 \mathrm{sf}\end{array}$} & $\$ 20,000.00$ \\
\hline & & & $\$ 49,968.00$ \\
\hline Subtotal - Building (per highest applicable cost area) & Equipment Specific & & $\begin{array}{r}\$ 0.00 \\
\$ 49,968.00\end{array}$ \\
\hline Total Direct Cost & & & $\$ 2,067,536,00$ \\
\hline \multicolumn{4}{|l|}{ Indirect Costs (Installation) } \\
\hline Engineering & $10 \%$ of $\mathrm{PEC}$ & & $\$ 146,880.00$ \\
\hline Construction and Field Expenses & $5 \%$ of PEC & & $\$ 73,440.00$ \\
\hline Start-up & $10 \%$ of PEC & & $\$ 146,880,00$ \\
\hline Performance Tests & $1 \%$ of PEC & & $\$ 14,688.00$ \\
\hline Contingencies & $15 \%$ of PEC & & $\$ 220,320.00$ \\
\hline Total Indirect Costs & & & $\$ 602,208.00$ \\
\hline Total Capital Costs (TCC) & & & $\$ 2,669,744.00$ \\
\hline
\end{tabular}

Source: Modified from EPA Handbook Control Technologies for Hazardons Air Pollutants (June 1991). 
24590-WTP-RPT-ENV-01-005, Rev. 0 Best Avallable Control Technology Analysis for Toxic Air Pollutants for the WTP

Table B-4. TBACT Control Technology Cost Estimate

Wet Caustic Scrubber

Stream S41

PT PJM/RFD Offgas Unabated

\begin{tabular}{|c|c|c|}
\hline Cost Item & Factor & Example Cost \\
\hline \multicolumn{3}{|l|}{ Direct Annual Costs } \\
\hline \multicolumn{3}{|l|}{ Utilities } \\
\hline Electricity & $\$ 0.08 / \mathrm{kWhr}$ & $\$ 0.00$ \\
\hline Steam & $\$ 6.00 / 1000 \mathrm{lb}$ & $\$ 0.00$ \\
\hline Water & $\$ 0.25 / 1000 \mathrm{gal}$. & $\$ 10,000.00$ \\
\hline Materials/Chemicals & Process Specific & $\$ 50,000.00$ \\
\hline \multicolumn{3}{|l|}{ Operating Expenses } \\
\hline Operator & $52 \mathrm{hr} / \mathrm{yr}$ & $\$ 1,040.00$ \\
\hline Supervisor & $15 \%$ of Operator & $\$ 156.00$ \\
\hline Secondary Waste T\&D & Process Specific & $\$ 0.00$ \\
\hline \multicolumn{3}{|l|}{ Maintenance } \\
\hline Labor & $24 \mathrm{hr} / 2 \mathrm{yr}$ & $\$ 204.00$ \\
\hline Materials & $100 \%$ of Maintenance Labor & $\$ 204.00$ \\
\hline \multicolumn{3}{|l|}{ Indirect Annual Costs } \\
\hline Overhead & $6 \%$ of Labor Costs & $\$ 840.00$ \\
\hline Administrative & $2 \%$ of TCC & $\$ 53,394.88$ \\
\hline Insurance & $1 \%$ of TCC & $\$ 26,697.44$ \\
\hline Total Annual Costs (TAC) & & $\$ 142,536.32$ \\
\hline Rate of Return on Capital Investment & $10.00 \%$ & \\
\hline Service Life (years) & 40 & \\
\hline Capital Recovery Factor & 0.1023 & \\
\hline Annualized Capital Investment (ACI) & & $\$ 273,006.46$ \\
\hline Grand Total Annualized Costs & $\mathrm{ACI}+\mathrm{TAC}$ & $\$ 415,542.78$ \\
\hline
\end{tabular}

Source: Modified from EPA Hancbook Control Technologies for Hazandous Air Pollutants (June 1991). 


\section{Appendix 2}

MERSOB ${ }^{\circledR}$ Mercury Adsorbents NUCON Bulletin 11B28, August 2004 


\title{
NUCON International, Inc
}

\section{MERSORB ${ }^{\circledR}$ Mercury Adsorbents}

\section{Design and Performance Characteristics}
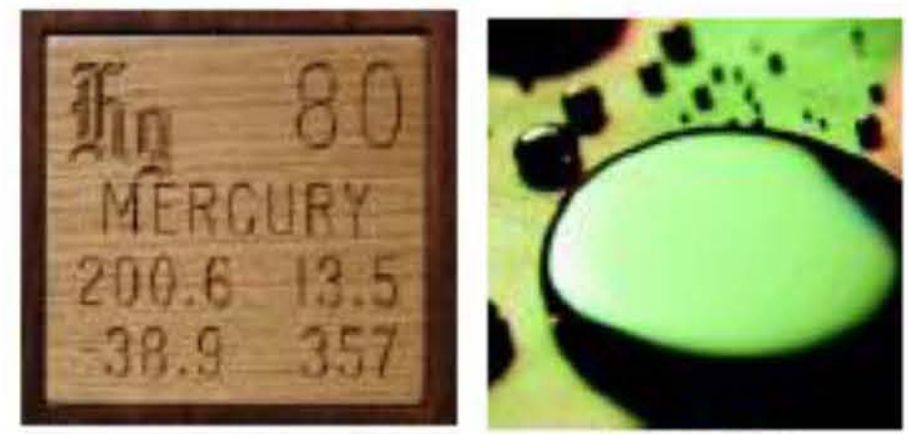

MERSORB ${ }^{\circ}-1.5$

MERSORB ${ }^{\circ}-3$

MERSORB ${ }^{6}-4$ MERSORB ${ }^{\circ}-$ LW $^{\circ}$ MERSORB ${ }^{\circ}$ - LH MERSORB ${ }^{6}-\mathrm{HT}$ MERSORB ${ }^{\circ}-\mathrm{CR}^{\circ}$

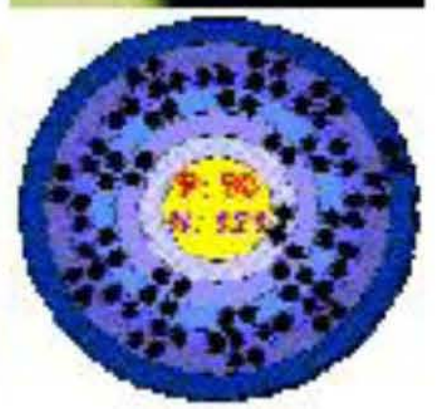

\section{NUCON Bulletin 11B28 - August 2004}

\author{
NUCON International, Inc \\ 7000 Huntley Road Columbus, OH 43229
}

Phone: 614-846-5710 Fax: 614-431-0858 http:l/www.nucon-int.com/ 


\section{NUCON International, Inc \\ 7000 Huntioy Rosd - Columbus, OH 43229 \\ Ph: 814-848-5710 - Fx: 814431-0958 - www nuoon-Intoom}

MERSORB

Meroury Adeorbents

Bulletin 11B28

Auguet 2004

\section{Table of Contents}

Section

Page

Background

Introduction

Physical Properties

Control Methods

Gas Phase Applications

Long Term Laboratory Tests

Adsorption Capacity 9

Particle Size Effects 10

Performance 10

Pressure Drop 11

Velocity Effects $\quad 12$

Temperature Effects $\quad 13$

Laboratory Test Results $\quad 15$

Liquid Phase Applications $\quad 16$

Mercury Removal From Water $\quad 16$

Adsorption Capacity $\quad 17$

Effect of Acidity 17

Oak Ridge National Laboratory Studies 18

Mercury Cell Chlorine Caustic Plant Waste $\quad 18$

Mercury Removal from Hydrocarbon Liquids 19

Case Histories $\quad 20$

Water from Air Scrubbers 20

Mercury Cel Hydrogen 20

LNG Production Plant - Hg/Natural Gas 20

Mine Atmosphere 20

Mercury Waste Recycler - Hg/Hot Retort Off-Gas 21

Mercury Waste Recycler - Hg/Water 21

Fluorescent Lamp Recycling System OEM - Hg/Air 21

Fluorescent Lamp Plant - Hg/Air 21

Mercury-Cell Chlor-Alkali Plant - Hg/Brine, HgWwater 22

$\begin{array}{ll}\text { Operating Guidelines } & 23\end{array}$

Technical Support $\quad 24$

References $\quad 25$ 


\section{NUCON International, Inc Towo Huntioy Rosd - Columbuc, OH 49229

\section{BACKGROUND}

Mercury is a historically important and useful industrial material. Mercury and mercury compounds have been used for thousands of years as pigments in inks (cinnabar, red sulfide), as aids to early metallurgy (gilding copper), and instrumentation (thermometers, barometers)-

Mercury is the only metallic element that is liquid at room temperature. It is present throughout the earth.

Mercury is toxic and human ingestion and exposure must be prevented. When present in industrial process fluids, mercury causes comosion and should be removed to prolong the life of the equipment.

Mercury has low vapor pressure and low solubility. Therefore, any mercury removal process must be effective at very low concentrations. Adsorption is such a process. Unimpregnated activated carbon is a fair adsorbent for mercury. But its capacity is significantly increased by impregnation with a material that chemically reacts with, and holds, the mercury. The choice of impregnant is dictated by the process conditions and the composition of the fluid. Sizing of adsorption equipment is determined by the flow rate of the fluid stream and the desired operational life of the adsorbent.

This bulletin describes NUCON" products and processes for control of mercury and its compounds. 


\section{INTRODUCTION}

Mercury is used in many industrial processes and products including:

a As the cathode in the generation of chlorine by electrolysis of chloride salts,

- Manufacture of batteries,

a Catalysts,

- Specialty chemicals,

a Fungicides.

a Electronics manufacturers use mercury for switches and measuring instruments.

- Mercury is present in fivorescent lamps, high intensity lamps and LCD computer screens.

Mercury is hazardous. The Threshold Limit Values-Time Weighted Average (TLV-TWA), established by AIGCH, is $0.05 \mathrm{mg}$ mercury per cubic meter air. "The typical concentration of mercury found in urban air is 0.000007 mg mercury per cubic meter. (In remote and rural areas it is approximately $10 \%$ of that level). These levels are considered harmless because they are 10 million times less than the TLV. However, in some industrial environments, concentrations as high as $5 \mathrm{mg}$ per cubic meter of air have been measured. This level is 100 times the TLV.

Many petroleum products contain mercury. A number of tests have been made to determine the concentration of mercury in natural gas supplies in various parts of the U.S. Locations in South Texas have shown concentrations ranging from $0.002 \mathrm{mg}^{3}$ to over $4.5 \mathrm{mg} / \mathrm{m}^{3}$. (1) Mercury is also present in condensates from other parts of the world such as Indonesia and North Africa.

The exhaust gases from waste incinerators and coal buming power plants contain mercury. It is estimated that half of the global emissions of mercury come from fossil fuel combustion. Although the total quantity emitted by waste incinerators is less, the concentrations are much higher.

Mercury-containing waste has contaminated soil and water. Materials containing mercury are sometimes stored in landills that are not completely isolated from the surrounding environment.

Mercury can amalgamate with metals used in process equipment, causing corrosion and failure. Therefore, natural gas processing and liquefaction plants use mercury adsorbents to protect their "cold box" heat exchangers. It is a poison for some catalysts used in hydrocarbon processing. Catalysts are protected in some ethylene plants, synthesis gas and steam reforming units and for hydrogen and ammonia production 


\section{NUCON International, Inc}

7000 Huntiey Rosd - Columbus, OH 40289

Ph: 614842-5710 - Fx: 614491-0858 - www nuoon-Intoom

MERSORBE

Meroury Adeorbente

Bulletin $11 \mathrm{Bz}$

Aupuct 2004

\section{PHYSICAL PROPERTIES}

General physical properties are shown in Table 1:

Table 1. Physical Properties of Mercury

$\begin{array}{ll}\text { Solubility in water } & 0.064 \text { mg per liter } \\ \text { Saturation concentration, } 20^{\circ} \mathrm{C} & 14 \mathrm{mg} \text { per cubic meter air } \\ \text { Melting point } & -38.9^{\circ} \mathrm{C} \\ \text { Boiling point } & 356.6^{\circ} \mathrm{C} \\ \text { Density } & 13.5 \mathrm{~g} \text { per ml } \\ \text { Molecular Weight } & 200.59\end{array}$

The solubility of mercury in hydrocarbon liquids at room temperature is shown in Table $2 .^{(5)}$

Table 2. Solubility of Mercury in Organic Liquids, mg/liter

\begin{tabular}{ll}
\hline Heptane & 1.3 \\
Benzene & 2.4 \\
Iso Octane & 0.8 \\
Isopropyl Ether & 1.0 \\
\hline
\end{tabular}

Typically, the solubility of mercury in hydrocarbons is ten times greater than in water. Since some geologic formations contain both liquid mercury and hydrocarbons, the natural gas and hydrocarbon liquids recovered can have very high mercury content. 


\section{CONTROL METHODS}

Most mercury control techniques use adsorbents (plain or impregnated) in some form. The high surface area of the adsorbents attracts the mercury and facil tates physical adsorption or chemical reaction. The most common base material is activated carbon. Impregnants are chosen for suitability in a particular environment.

NUCON International, Inc. (NUCON) has developed the MERSORB' family of adsorbents for almost every type of mercury removal application.

For processing natural gas, hydrocarbon liquids, and smal air streams, fxed beds of pelleted MERSORB* adsorbents are used. Even though the adsorbents are optimized for maximum mass transfer rates, the relatively slow reaction rate of the mercury vapor with the impregnant requires a relatively long residence time. The amount of adsorbent required to achieve high removal efficiency will general y give a very long service life.

When mercury is present at very low concentrations in relatively large gas streams (such as effluent gases from coal fired power plants or waste incinerators), powdered adsorbents can be used. The powdered adsorbents can be injected into the gas stream and, after an appropriate residence time, filtered out in a dust collector. Tests have shown various degrees of effectiveness.

\section{GAS PHASE APPLICATIONS}

Various diffusion processes control the rate of mercury removal by impregnated carbons. Bulk diffusion to the surface of the particle, pore diffusion, and reactant and reaction-product diffusion in the deposited impregnant layer all affect performance. NUCON base adsorbents have been selected for their optimized pore structure.

MERSORB* adsorbents:

- Are well suited for protecting catalyst beds and aluminum heat exchangers

- Remove mercury from process-gas streams.

- Have high capacity and removal efficiency, and low-pressure drop.

MERSORB* is a registered trademark of NUCON Intemational, Inc. 


\section{NUCON International, Inc}

7000 Huntiey Rosd - Columbus, OH 49228

Ph: s14848-5710 - Fx: 814481-0858 - www nuoon-Int oom
MERSORBE

Maroury Adeortente

Butlotin 11828

August 2004

\section{Long-Term Laboratory Tests}

Mercury removal efficiency and adsorption capacity testing, using radioactive mercury, have been performed in the NUCON radioisotope laboratory using ${ }^{150} \mathrm{Hg}$.

The test parameters were:

\section{Gas \\ Temperature: \\ Bed Diameter: \\ Bed Depth: \\ Particle Size: \\ Inlet Concentration: \\ Pressure: \\ Linear Velocity:}

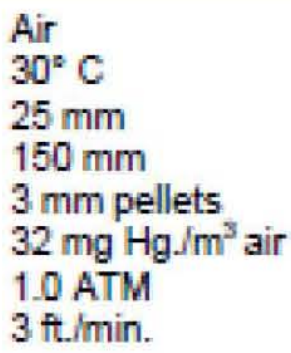

3 ft.lmin.

Tests were conducted using six bed segments, each being $25 \mathrm{~mm}$ deep and $25 \mathrm{~mm}$ diameter.

The radioactive isotope content of the samples of gas between the segments was analyzed at periodic intervals. The results of the tests for mercury removal from air are shown in Figure 1.

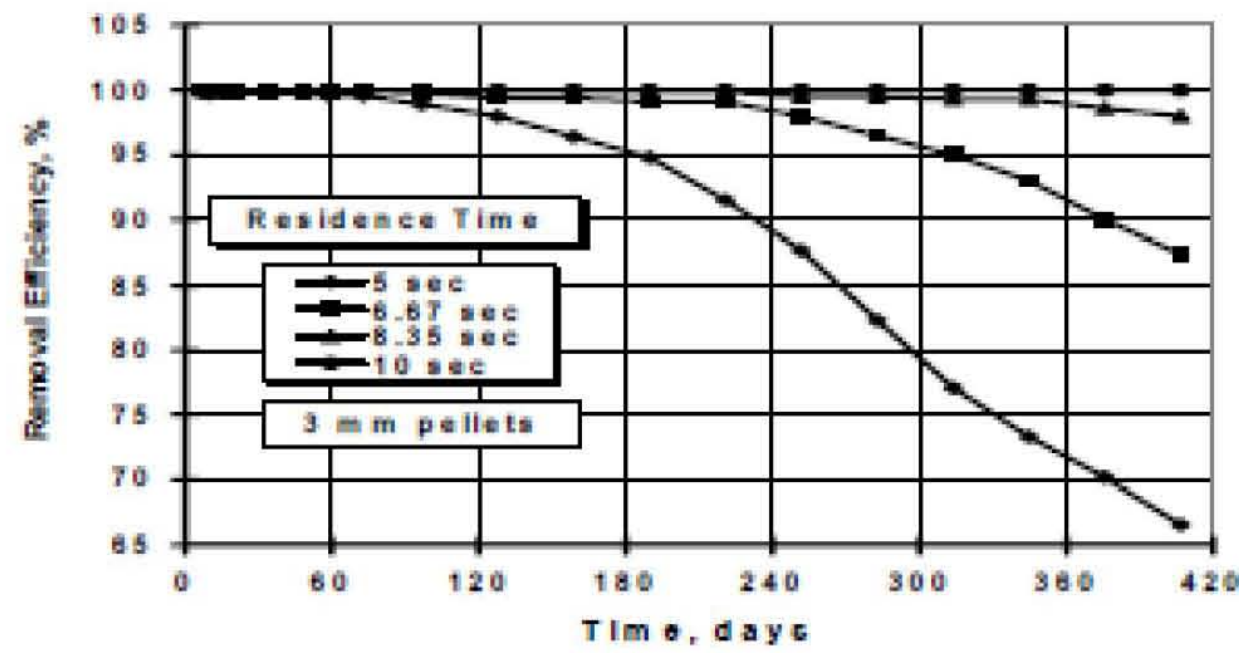

Figure 1 - Mercury Removal Efficiency from Air at Various Residence Times 


\section{NUCON International, Inc}

7000 Huntlow Rosd - Columbut, OH 4982:

Ph: s14-848-5710 - Fx: 614431-0868 - mww nuoon-Intoom
MERSORBE

Meroury Adeortente

Bullitin 11 azs

August 2004

Similar tests for mercury removal efficiency and capacity from natural gas have also been performed. The test parameters were the same as in the air tests. Results are shown in Figure 2.

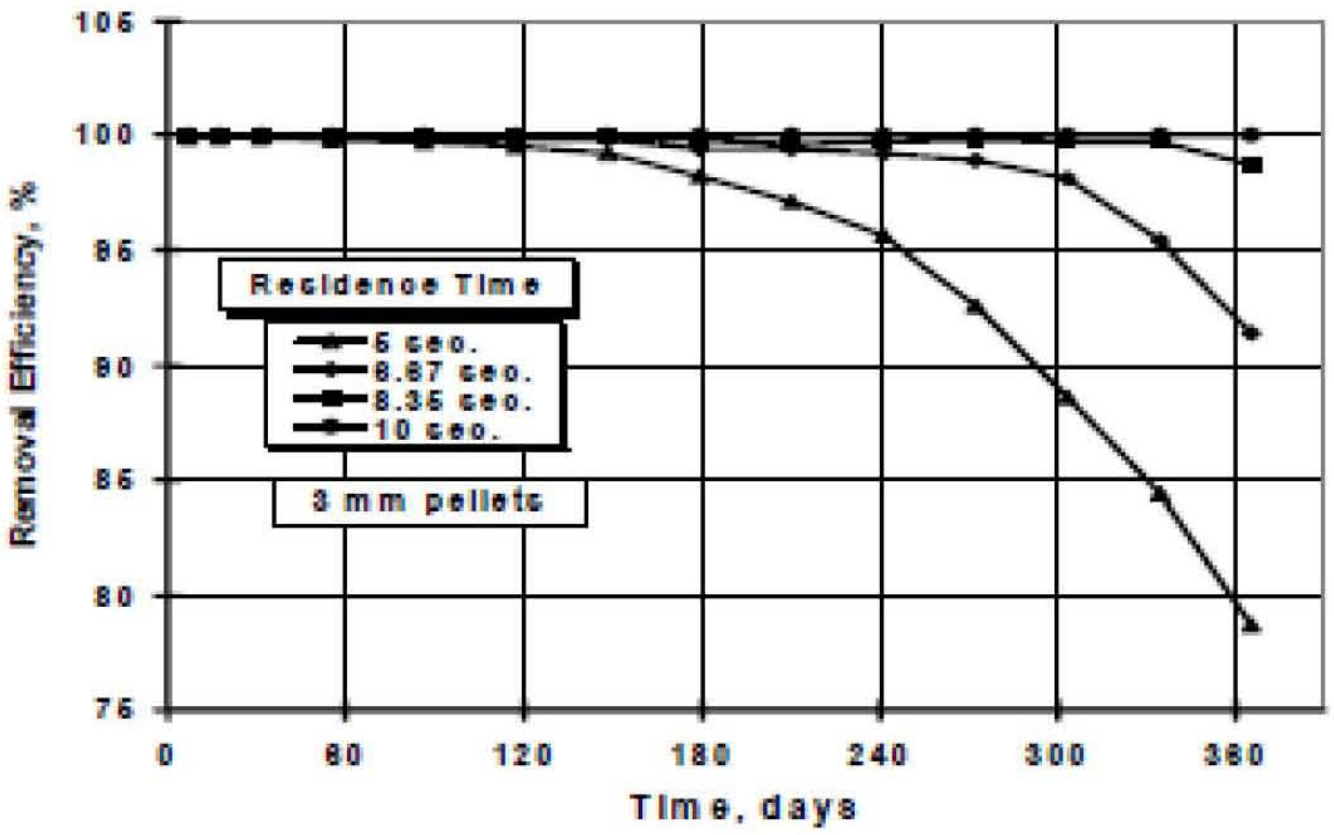

Figure 2 - Mercury Removal Efficiency from Natural Gas at various Residence Times

For both air and natural gas, when the gas stream is saturated with mercury, a 10-second residence time is recommended to achieve complete removal of the mercury. At these high concentrations, MERSORB ${ }^{*}$ adsorbent removed $100 \%$ of the mercury for over one year. In most commercial applications the mercury concentration is only a fraction of the saturation level, and the life of the MERSORB" adsorbent is typically several years.

An altemate approach can be used if removal efficiencies of less than $100 \%$ are acceptable. A smaller bed will give adequate performance for a slightly shorter period of time. For example, a 5 second residence time provided 240 days life at efficiencies above $95 \%$ in the natural gas tests (Figure 2). Similarly, at low mercury concentrations, $100 \%$ removal can be achieved at less than 10 seconds residence time. 


\section{NUCON International, Inc}

7000 Huntiey Rowd - Columbus, OH $432 \%$

Fh: 614-848-5710 - Fx: B14-491-0968 - www nuobn-Intoom

MERSORBE

Meroury Adcorbente

Bullatin 11B28

Aupuct 2004

\section{Adsorption Capacity}

The theoretical equilibrium adsorption capacity of MERSORB* pellets is $85 \mathrm{~g} \mathrm{Hg} / 100 \mathrm{~g}$ MERSORB* adsorbent. However, it is impractical to reach that level in commercial applications. An extremely long time would be required to obtain diffusion of the mercury into the adsorbent and for the chemical conversion to take place. In the region of the mass transfer zone, the amount adsorbed is always less than the maximum. Dynamic adsorption capacity data for the extended dynamic adsorption tests are shown in Table 3 .

Table 3. Dynamic Adsorption Capacity of MERsoRB ${ }^{\odot} 3 \mathrm{~mm}$ Pellets

\begin{tabular}{|ccc|}
\hline & Air & Natural Gas \\
Test Duration, days & 407 & 365 \\
\hline Bed Segment No. & & Amount Adsorbed, \\
& & g Hg/100 g MERSORB \\
1 & 23 & 31 \\
2 & 19 & 28 \\
3 & 15 & 19 \\
4 & 15 & 14 \\
5 & 14 & 0.3 \\
6 & 0.3 & \\
\hline
\end{tabular}

While Bed Segment No. 6 adsorbed a small amount of mercury, there was no detectable breakthrough from the bed at the end of the test. 


\section{NUCON International, Inc}

7000 Huntley Rosd - Columbus, OH 49289

Fh: 614842-5710 - Fx: 814-491-0688 - mww nuoon-Intoom

MERSORBD

Uoroury Adcorbente

Bullotin $11 \mathrm{~B} 28$

Auguct 2004

\section{Particle Size Effects}

The particle size of the MERSORB ${ }^{*}$ adsorbent affects several operating parameters. Data concerning the two most important criteria, performance and pressure drop, has been developed.

\section{Performance}

The dynamic performance of small particle size adsorbents is always better than for that of larger sizes. Figure 3 shows the difference in performance between MERSORB ${ }^{*} 1.5 \mathrm{~mm}$ and $3 \mathrm{~mm}$ pelets. These tests were conducted using air saturated with mercury at $30^{\circ} \mathrm{C}$. The test bed dimensions were $25 \mathrm{~mm}$ diameter by $25 \mathrm{~mm}$ long.

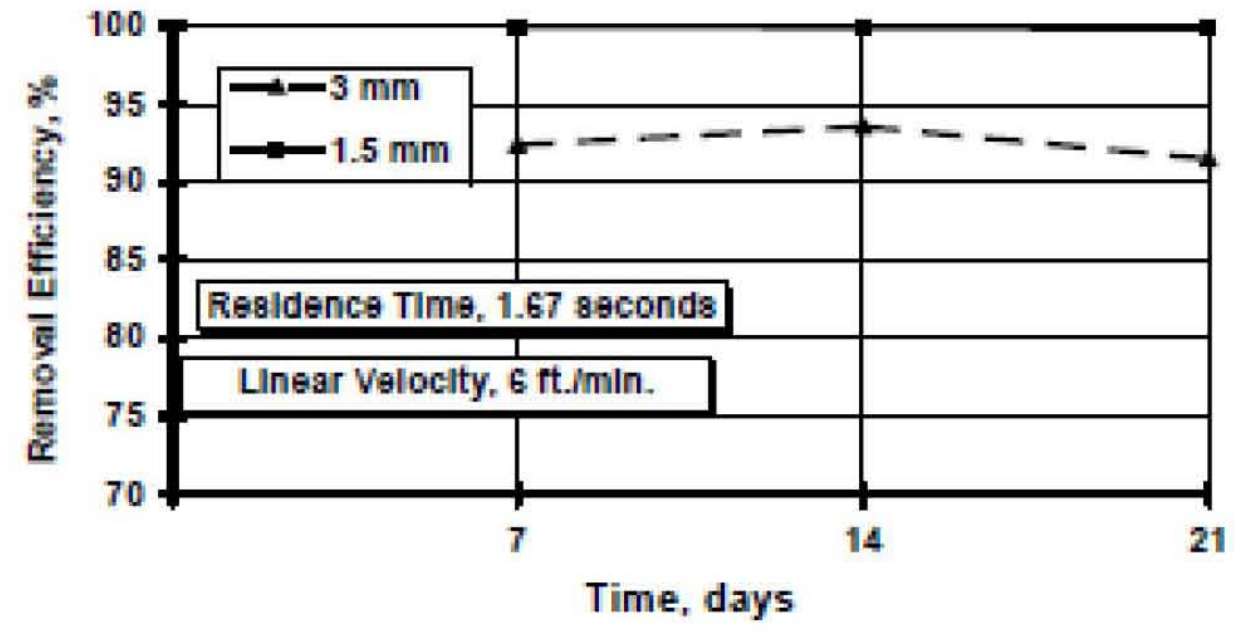

Figure 3 - Effect of Particle Size on Mercury Removal from Air

The difference is very noticeable at short residence times. The initial efficiency for $1.5 \mathrm{~mm}$ pellets at 1.67 seconds residence time is $100 \%$, while for $3 \mathrm{~mm}$ it is around $93 \%$. 


\section{NUCON International, Inc}

7000 Huntiey Rosd - Columbus, $\mathrm{OH} 4928$

Ph: 614848-57t0 - Fx: 814-491-0858 - wwwnuoon-Intoom
MERSOREW

Heroury Adcorbente

Bullotin 11B28

Auguct 2004

\section{Pressure Drop}

The pressure drop through a packed bed increases as particle size decreases. Pressure drop curves for MERSORB" pellets at atmospheric pressure are shown in Figure 4.

Figure 4 - Pressure Drop of Air Through Packed Beds

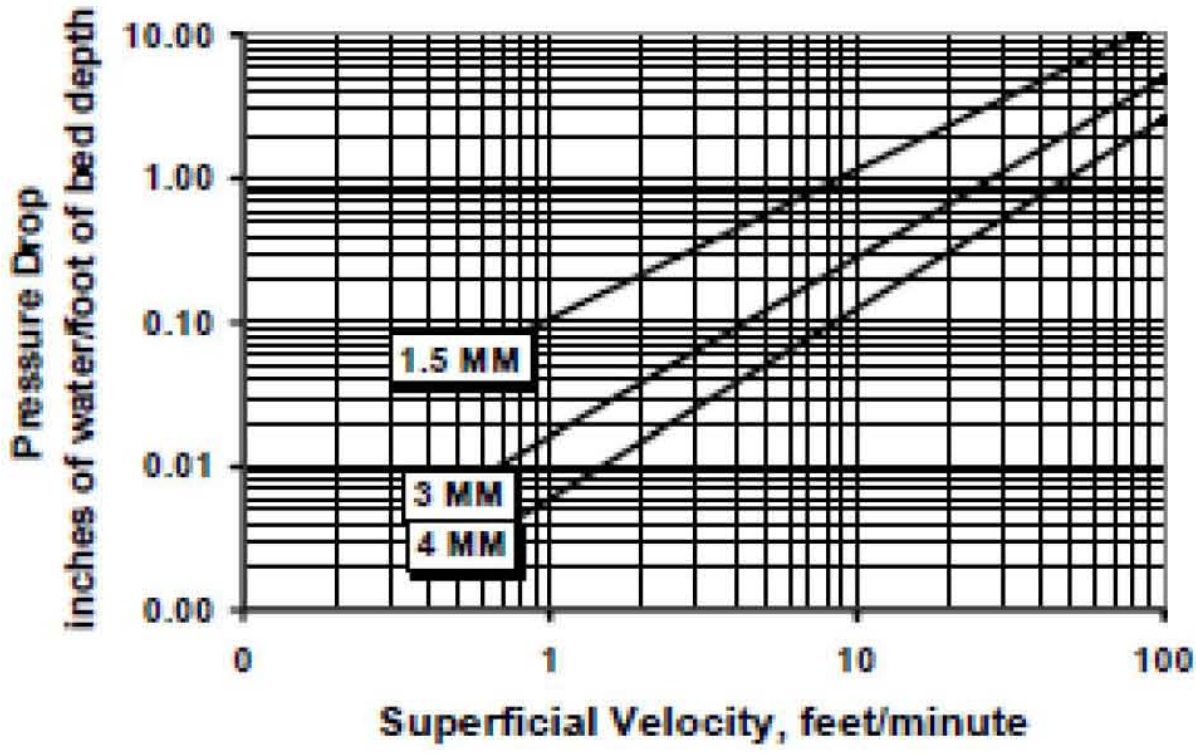

Natural gas processing is nomally done at high pressure. Flow resistance for a typical operating pressure is shown in Figure 5 . 


\section{NUCON International, Inc}

7000 Huntley Rosd - Columbus, OH 49228

Ph: 514-848-5710 - Fx: 614-431-0568 - www nuoon-Intoom

\section{Velocity Effects}

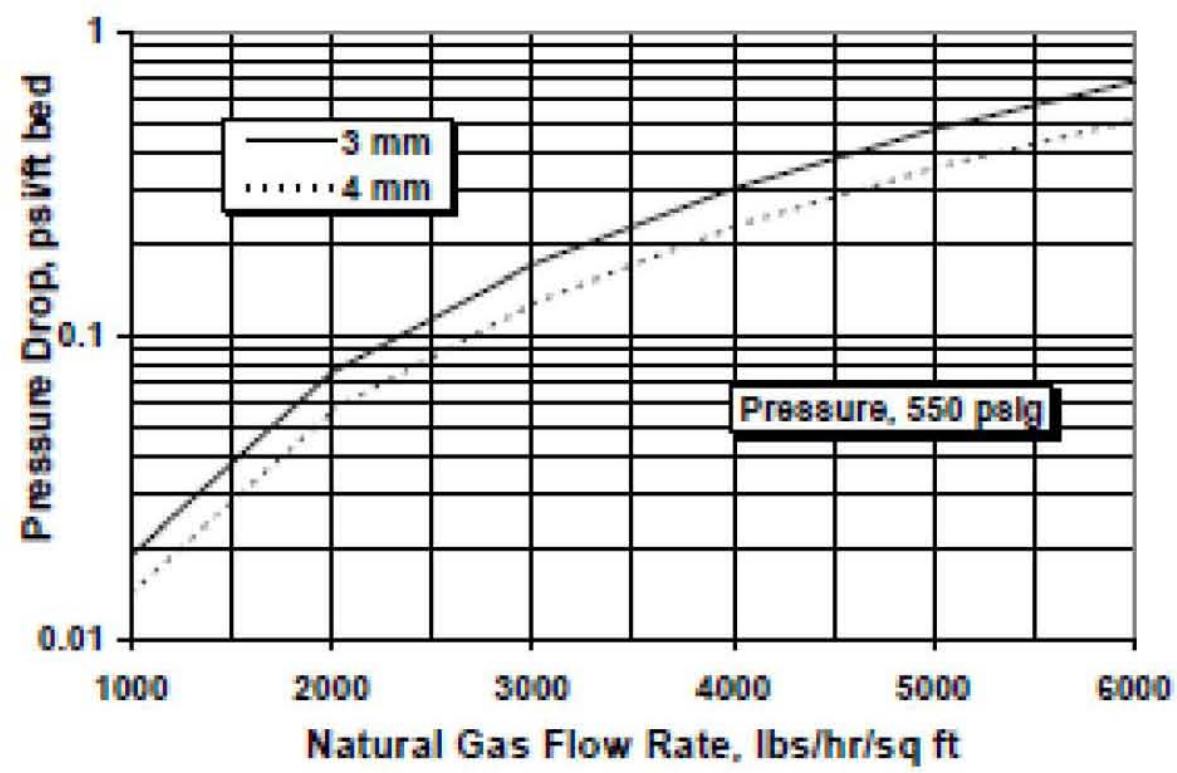

Figure 5 - Pressure Drop Through MERSORB $\odot$ Pelleted Adsorbent NUCON ran laboratory tests on $4 \mathrm{~mm}$ MERSORBt pellets using two different gas velocities with the bed depth of 12 inches. The comparative results after 30 days of testing are shown in Table 4.

Table 4. Effect of Velocity on Dynamic Adsorption

\begin{tabular}{ccc}
\multicolumn{3}{c}{ Removal Efficiency $(\%)$} \\
Residence Time, sec & $3 \mathrm{ft} / \mathrm{min}$ & $6 \mathrm{ft} / \mathrm{min}$ \\
1.67 & 42.8 & 58.4 \\
3.33 & 80.3 & 88.7 \\
5.00 & 90.7 & 100.0
\end{tabular}

Removal efficiency is general y perceived as a function of the residence time. However, at higher superficial gas velocity, the removal efficiency at a given residence time improves due to favorable diffusion effects. 


\section{NUCON International, Inc \\ 7000 Huntiey Rosd - Columbus, OH 43229 \\ Ph: 614-848-5710 - Fx: 814481-0858 - www nuoon-Intoom}

MERSOREV

Meroury Adecrbente

Bulletin $11 \mathrm{B28}$

Auguct 2004

\section{Temperature Effects}

Operation of mercury removal systems at high temperatures is sometimes necessary. There are two major effects upon performance at elevated temperatures. The sulfur impregnant can:

- Vaporize in inert atmospheres, or

- Oxidize in air atmospheres.

NUCON uses a unique manufacturing method to make the MERSORB' sulfur-impregnated adsobents. The result is a product that retains the impregnant better at high operating temperatures than the adsorbents manufactured by others. Themogravimetric analysis of the NUCON and competitive product has substantiated this fact.

The results of thermogravimetric analysis of samples of $3 \mathrm{~mm}$ MERSORB* mercury adsorbent and a competitive $4 \times 10$ mesh size granular adsorbent are shown in Figure 6 . For the compettive (granular) product, almost half of the impregnant was lost at temperatures around the boiling point of water. On the other hand, the MERSORB* shows no weight loss unt the temperature exceeds $200^{\circ} \mathrm{C}$.

The differences are even more noticeable for tests conducted in air (See Figure 7). The weight loss at temperatures above $275^{\circ} \mathrm{C}$ for the competitive product indicates that both the sulfur impregnant and some of the carbon is being oxidized. For the NUCON MERSORB* material, only a small portion of the sulfur is lost at that temperature.

A special grade, MERSORB* HT, is available for high temperature applications (greater than $100^{\circ} \mathrm{C}$ ). Through a unique manufacturing process, the sulfur is converted to a form that is very stable. The weight loss of MERSORB ${ }^{*} \mathrm{HT}$ when subjected to a temperature of $200^{\circ} \mathrm{C}$ is typically $2 \%$. 


\section{NUCON International, Inc}

7000 Huntiey Rosd - Columbuc, OH $4928 \mathrm{~s}$

Ph: 614-842-5710 - Fx: 614491-0858 - mww nuoon-Intoom

\section{Weight Loss}

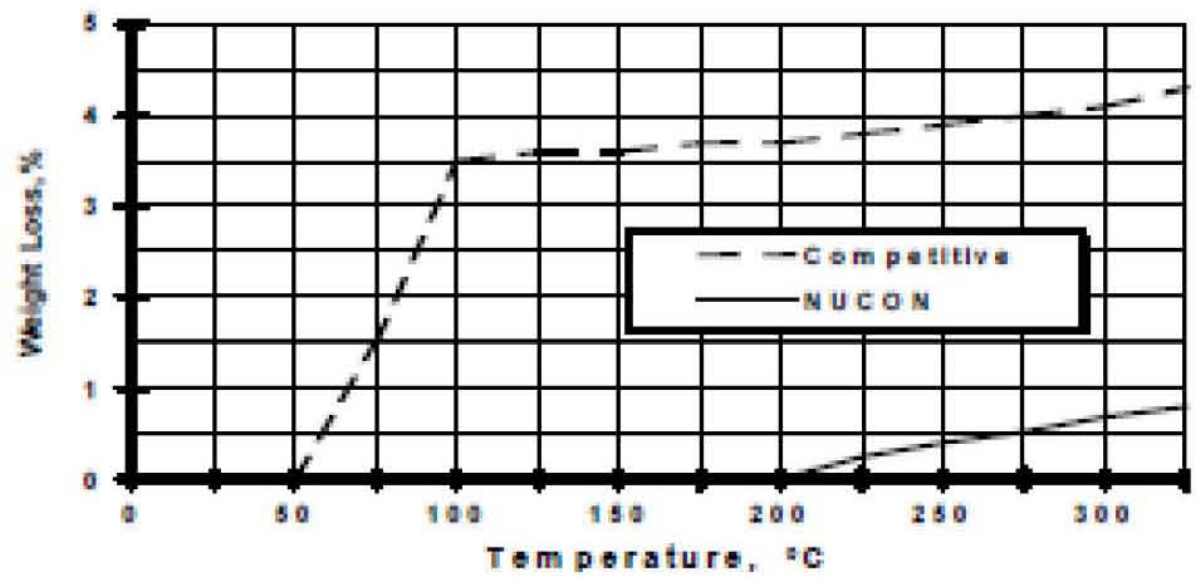

Figure 6-Weight Loss of Mercury Adsorbents in Inert Atmosphere

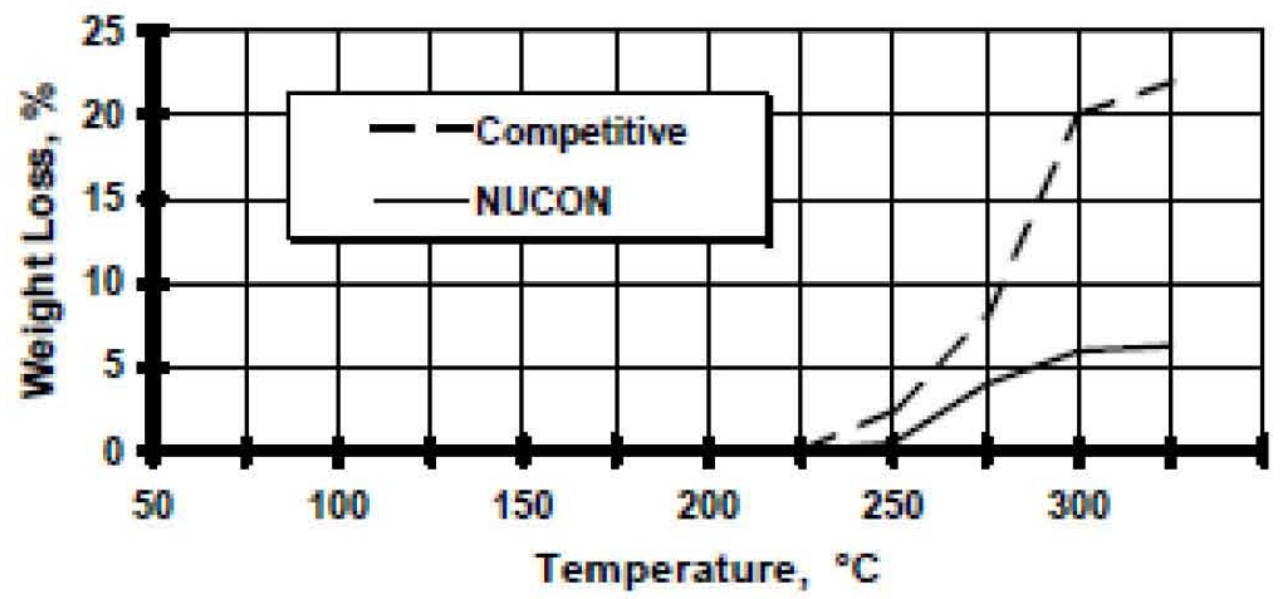

Figure 7 - Weight Loss of Mercury Adsorbents in Air 


\section{NUCON International, Inc}

7000 Huntiey Rosd - Columbus, $\mathrm{OH} 4928 \mathrm{~s}$

Ph: e-14848-5710 - Fx: 614-491-0858 - www.nuoon-Intoom

All thermogravimetric tests were performed on carbon that had been dried to remove moisture.

Other tests were conducted with a stream of methane flowing through a bed of MERSORB 1.5 pellets at $150^{\circ} \mathrm{C}$. After 24 hours, the impregnant loss was only $0.5 \%$.

The MERSORB* sulfur impregnated adsorbents are quality control tested at $200^{\circ} \mathrm{C}$ to insure stability of the impregnant.

The typical loss of impregnant content for MERSORB* HT is $2 \%$.

\section{LABORATORY TEST RESULTS}

The results of laboratory tests performed on several simulated gas streams have been used as a basis for the design of mercury removal processes. They include offgas from mixed waste incineration, a plasma enhanced melter, ventilation of a hot cell, and a chemical munitions incineration process. Table 5 shows the results of these tests.

Table 5. Laboratory Experiments, Gas Phase Mercury Removal

\begin{tabular}{|c|c|c|c|c|}
\hline Application & $\begin{array}{l}\text { Mlxed Waste } \\
\text { Incineration" }\end{array}$ & $\begin{array}{l}\text { Mlxed Waste } \\
\text { Incineration }\end{array}$ & $\begin{array}{l}\text { Hot Cell Vent } \\
\text { SNS Facilltes }\end{array}$ & $\begin{array}{l}\text { Plasma- } \\
\text { Enhanced } \\
\text { Incineration }{ }^{12}\end{array}$ \\
\hline Gas. & Inert Off Gas & Inert Off Gas & Air & Syngas \\
\hline Impurities & $\mathrm{NO}_{2}, \mathrm{HCL}$ & & & Nitrogen \\
\hline Mercury Conc., mg'cu m & 10 & 16 & 0.055 & 0.55 \\
\hline Temperature, ${ }^{\circ} \mathrm{C}$ & 150 & 107 & 38 & 30 \\
\hline Residence Time, sec & 0.99 & 0.63 & 0.7 & 20 \\
\hline Test Duration, hr & 1000 & 100 & 60 & $\theta$ \\
\hline Mercury Removal Eff., \% & 99.9 & 99.997 & 90.8 & 90.99 \\
\hline
\end{tabular}




\section{NUCON International, Inc \\ 7000 Huntley Rosd - Columber, OH 43228 \\ Ph: 614848-6710 - Fx: 814-491-0858 - wwwnuoon-Intoom}

MERSORBN

Moroury Adcorbente

Bullotin $11 \mathrm{~B} 28$

Auguet 2004

\section{LIQUID PHASE APPLICATIONS}

NUCON also produces mercury removal adsorbents for liquid phase applications. The MERSORB ${ }^{*} L$ designation is used for products designed to remove mercury from the liquid phase. There are two products used for liquid phase application:

- MERSORB ${ }^{*}$ LW for liquid phase, aqueous solutions

- MERSORB" LH for liquid phase hydrocarbons

The impregnant used to make LW grade is insoluble in water. The impregnant used to make $\mathrm{LH}$ grade is insoluble in common hydrocarbons.

The standard LW and the LH grades are supplied as 1.5 and $0.9 \mathrm{~mm}$ diameter pellets. Custom particle sizes are available.

\section{Mercury Removal from Water}

The MERSORB* LW grades chemically react with elemental mercury or water-soluble mercury salts within the pore structure of the adsorbent. Even though the solubility of elemental mercury in water is low ( 0.064 mg/iter), environmental authorities often specify even lower levels. Soluble mercury sats can be present at much higher concentrations in various contaminated streams.

The mercury adsorption capacity of MERSORB ${ }^{*} L W$ is concentration dependent. Typical design contact times are in the range of $20-40$ minutes at ambient temperature. The MERSORB ${ }^{*} \mathrm{LW}$ grades can be used at temperatures up to $90^{\circ} \mathrm{C}$.

If large amounts of dissolved organic material are also present in the aqueous streams, an unimpregnated carbon (NUSORB" GC80-1.5) should be used as a guard bed to increase the life and efficiency of the MERSORB ${ }^{*}$ LW for mercury removal.

\section{Adsorption Capacity}

Figure 8 shows an isothem for adsorption of ionic mercury from water. Water $(\mathrm{pH} 7)$ containing $50 \mathrm{ppm}$ mercury (as $\mathrm{Hg}^{22}$ from $\mathrm{HgCl}_{2}$ ) was contacted with various amounts of MERSORB ${ }^{*}$ LW-3 ground to -325 mesh. After 24 hours the carbon was filtered out and the residual mercury concentration in the filtrate was determined by Atomic Absorption Spectroscopy. 


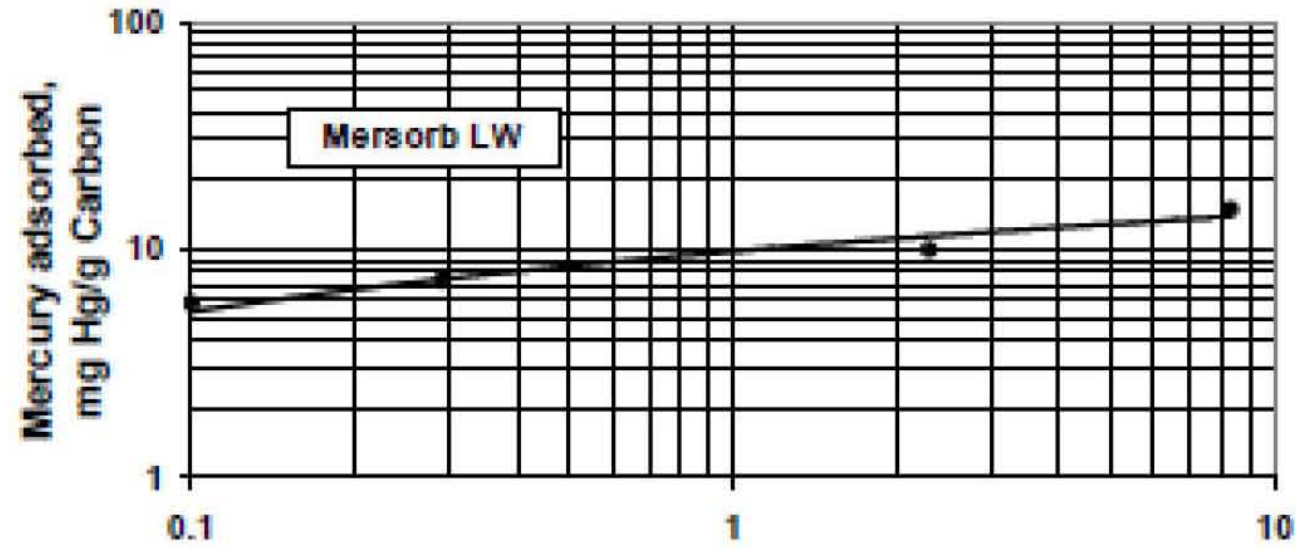

Concentration, mg Hg/liter

Figure 8 - Adsorption of Mercury from Water by MERSORB ${ }^{\circ}$ LW

\section{Effect of Acidity}

The $\mathrm{pH}$ of the water influences the adsorption capacity for mercury. MERSORB" LW was ground to -325 mesh and $0.1 \mathrm{~g}$ was mixed with $100 \mathrm{ml}$ of reagent grade water containing 97.4 mg mercuryliter water. The $\mathrm{pH}$ was adjusted with $\mathrm{NaOH}$ solution. The residual mercury concentration was measured after 24 hours. Those results are shown in Table 6.

Table 6. Effect of pH on Mercury Removal

\begin{tabular}{lllll}
\hline $\mathrm{pH}$ & 3.2 & 7 & 8 & 10 \\
Amount removed, \% & 44 & 80 & 85 & 99 \\
\hline
\end{tabular}

Less than half of the mercury was removed at $\mathrm{pH} 3.2$ whle over $99 \%$ was removed at $\mathrm{pH} 10$.

The effect of other ions in the water on mercury adsorption can be substantial. Contact your MERSORB" applications engineer for advice in these cases. 


\section{NUCON International, Inc}

7000 Huntiey Rosd - Columbus, OH 49228

Ph: 614848-5710 - Fx: 614-491-0858 - mww.nuoon-Intoom
MERSORBẼ

Seroury Adcorbente

Bullotin $11 \mathrm{~B} 28$

Auquat 2004

\section{Oak Ridge National Laboratory Studies}

Moxed wastes containing mercury must be treated at a number of nuclear facilities. As a part of a program to obtain preliminary technical data, a team at Oak Ridge National Laboratory performed lab studies using a solution of mercury in water synthesized to duplicate some of the actual wastes. ${ }^{(6)}$ They found that MERSORB ${ }^{*}$ LW was effective in this application. By varying solution conditions, they found that mercury uptake was slightly slower at low pH and that competing cations reduced the total amount of mercury removed. While the theoretical capacity is $0.71 \mathrm{~g} / \mathrm{g}$ of MERSORB ${ }^{*} \mathrm{LW}$, at the low concentrations used for the tests, the capacity was $0.12 \mathrm{~g} / \mathrm{g}$ at neutral $\mathrm{pH}$. The rate of mercury adsorption was found to follow firstorder kinetic behavior.

In another study, MERSORB ${ }^{*}$ LW was evaluated for its mercury removal from water streams which contain dissolved mercury salts ${ }^{(0)}$ In these experiments, the weight Distribution Coefficient (D), that is, the adsorbed amount per kilogram of dry adsorbent divided by the amount per liter of solution, was determined at two mercury concentrations from a $0.05 \mathrm{M}$ sodium nitrate and a $0.05 \mathrm{M}$ sodium chloride solution. The mercury in the infuent was present as $\mathrm{Hg}^{* 2}$.

Table 7. Distribution Coefficient of $\mathrm{Hg}^{+2}$ on MERSORB ${ }^{*} \mathrm{LW}$

\begin{tabular}{crr}
\hline $\mathrm{Hg}^{* 2}$ Salt Concentration & Trace & $0.001 \mathrm{~mol} \mathrm{Hg} / \mathrm{kg}$ \\
From $0.05 \mathrm{M} \mathrm{NaN0}_{3}$ & $16,500(\mathrm{lkg})$ & $76,200(/ \mathrm{kg})$ \\
From $0.05 \mathrm{M} \mathrm{NaCl}$ & $1,000,000(/ \mathrm{kg})$ & $175,000(/ \mathrm{kg})$
\end{tabular}

\section{Mercury Cell Chlorine Caustic Plant Waste}

Wastewater discharges from the HoltraChem chlor-alkali plant in Maine exceeded the newly established mercury concentration limits imposed by the EPA ${ }^{D}$. An extensive process system was installed which included optimization of the sulfide pre-treatment step, adjustment of $\mathrm{pH}$ and the addition of 0.5 micron particle fiters, followed by a polishing bed of MERSORB* LW mercury adsorbent. The result was a reduction in the effluent concentration to below 50 ppTw. Process conditions for the MERSORB" adsorber were:

Flow:

Residence time

Inlet Mercury Concentration

$100 \mathrm{gpm}$

Mercury Removal Efficiency

$$
\begin{gathered}
45 \text { minutes } \\
8 \text { ppb } \\
\text { 98.64\% }
\end{gathered}
$$




\section{NUCON International, Inc}

7000 Huntiey Road - Columbue, OH 4928

Ph: 614848-5710 - Fx: 814-481-0868 - mww nuoon-Int oom

MERSORBV

Heroury Adecrbente

Bullotin 11B28

Auguet 2004

\section{Mercury Removal from Hydrocarbon Liquids}

Tests have been performed in the NUCON laboratory using MERSORB' ${ }^{\mathrm{L}} \mathrm{H}$ to remove elemental mercury from heptane. Equilbrium adsorption results are shown in Figure $\theta$.

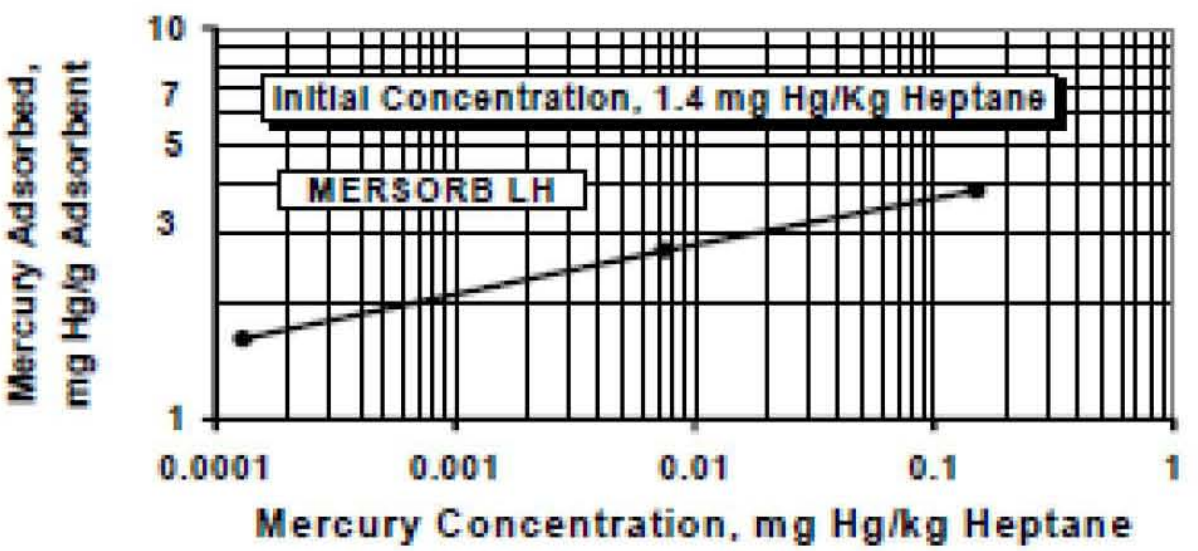

Figure 9 - Mercury Adsorption from Heptane, MERSORB ${ }^{6}$ LH 


\section{NUCON International, Inc}

7000 Huntiey Fosd - Columbus, OH 49259

Fh: 514848-5710 - Fx: 614491-0868 - mww nucon-Intoom

MERSORBS

Meroury Adscrbente

Bullotin $11 \mathrm{~B} 28$

Auguet 2004

\section{CASE HISTORIES}

\section{Water from Air Scrubbers}

For some small medical waste incinerators, the exhaust gas is passed through a water scrubber to remove particulates and water-soluble compounds. Any mercury present in the waste is contained in the scrubber water. During a four-month demonstration project. scrubber water containing an average of $300 \mathrm{ppbw} \mathrm{Hg}$ was passed through a column of MERSORB ${ }^{*}$ LW to remove the mercury. An average effluent level of less than $2 \mathrm{ppbw} \mathrm{Hg}$ was maintained over this period.

\section{Mercury Cell Hydrogen}

High purity hydrogen chloride $(\mathrm{HCl})$ is manufactured by reacting hydrogen and chlorine. A facility using hydrogen from chlorinelcaustic mercury cells must remove the mercury in the hydrogen to meet specifications for the $\mathrm{HCl}$. Mercury concentrations up to $300 \mathrm{ppb}$ were reduced to less than 0.01 ppb in a single column of MERSORB 3 mm diameter pellets. This system has been in operation for over eight years with $100 \%$ mercury removal efficiency.

\section{LNG Production Plant-Hg in Natural Gas}

A westem USA natural gas processing plant produces LNG in order to reject nitrogen from the gas. This plant has its mercury removal section upstream of the $\mathrm{CO}_{2}$ removal section. The plant was using a competitive mercury adsorbent and suffered mercury corrosion downstream due to poor mercury removal efficiency. Sulfur contamination in the NGL was also observed, due to loss of sulfur from the mercury adsorbent caused by water-glyod carryover. The plant instal ed MERSORB" mercury adsorbent and sulfur contamination of their NGL was eliminated and the concentration mercurylcubic meter in the treated gas is consistently $<2$ nanograms.

\section{Mine Atmosphere}

A gold mining plant in Nevada encountered concentrations well above the TLV in the enclosed processing area. An air purification system containing MERSORB* $3 \mathrm{~mm}$ pelets was installed. The mercury level has been reduced to below the TLV. 


\section{NUCON International, Inc \\ 7000 Huntioy Rasd - Columbuc, OH 4922 \\ Ph: 614848-5710 - Fx: 614481-0568 - www nuoon-Intoom}

MERSORBD

Ueroury Adcorbente

Bullotin $11 \mathrm{~B} 28$

Auguet 2004

\section{Mercury Waste Recycler- $\mathrm{Hg}$ in Hot Retort Off-Gas}

A recycler plant uses a retort to process its mercury-bearing wastes. Using a competive mercury adsorbent to filter the $250^{\circ} \mathrm{F}$ off-gas, they experienced repeated bed fires. After lab testing all available mercury adsorbents, they switched to MERSORB" mercury adsorbent. There have been no further problems with bed fires and mercury emission requirements are met.

\section{Mercury Waste Recycler- $\mathrm{Hg}$ in Water}

Treating retort condensate water for mercury removal using a competitor's product did not achieve the desired performance. After instal ing MERSORB" LW mercury adsorbent, the user reduced mercury levels in the treated water from as high as $1,000 \mathrm{ppbw} \mathrm{Hg}$ to less than 1 ppbw $\mathrm{Hg}$.

\section{Fluorescent Lamp Recycling System OEM-Hg in Air}

An OEM tried several competitive mercury adsorbent products and decided to use MERSORB ${ }^{*}$ mercury adsorbent. Over 20 systems instal ed all meet mercury emissions regulations. Even with a three-shift lamp recycling operation, the mercury adsorbent lasts several years.

\section{Fluorescent Lamp Plant- $\mathrm{Hg}$ in Air}

The plant needed to control the mercury emissions from their fluorescent lamp curing ovens. An air collection system was installed, including an adsorber containing MERSORB ${ }^{*}$ LH mercury adsorbent. Mercury concentrations around the unit were reduced from > 100 micrograms $\mathrm{Hg}$ /cubic meter to non-detectable levels of $<1$ microgram Hglcubic meter, even though the treated air temperature was over $160^{\circ} \mathrm{F}$.

\section{Mercury-Cell Chlor-Alkali Plant- $\mathrm{Hg}$ in Brine, $\mathrm{Hg}$ in Water}

The plant needed to drastical y reduce the mercury emissions in its spent brine. A 100 gpm secondary treatment system using MERSORB* LW mercury adsorbent was instal ed. The process reduced mercury levels in the brine from $>50 \mathrm{ppbw} \mathrm{Hg}$ to $<0.050 \mathrm{ppbw} \mathrm{Hg}$ ( $<50$ ppTrillion $\mathrm{Hg}$ by weight). 


\section{OPERATING GUIDELINES}

The following are general guidance for typical applications. Contact us to discuss MERSORB* applications tailored to your specific operating conditions.

1. Do not use these products for acidic solutions. Acids reacting with sulfur compounds can generate hydrogen sulfide $\left(\mathrm{H}_{2} \mathrm{~S}\right)$, which is poisonous. Removal efficiency for ionic mercury decreases at a pH below 7 . For elemental mercury, apH as low as 4 can be used.

2. When non-mercury impurities must also be removed, it may be desirable to use "guard" adsorbent beds in service upstream of the MERSORB" adsorbent beds to remove these impurities and increase the life of the mercury adsorption bed.

3. Mercury removed by the sulfur impregnated MERSORB ${ }^{*}$ is converted by the adsorbent to mercuric sulfide, a naturaly occurring compound. Spent adsorbent should be handled according to appropriate disposal procedures and according to applicable safety and transportation regulations.

4. For optimum removal efficiency, it is always preferable to operate a deep bed at high velocity rather than shallow adsorbent bed at a low velocity.

5. It is important to have effective liquid knockout upstream of gas phase mercury adsorption beds. Liquid hydrocarbons can dissolve the sulfur impregnant. Anyliquids entering or condensing in the adsorbent bed interfere with the mercury adsorption rate and capacity. It is also common for natural gas streams to be saturated with water. Since high relative humidity interferes with mercury adsorption, it is important to raise the temperature of the gas enough to reduce the relative humidity less than $90 \%$. This will also minimize the possibility of getting liquid water on the adsorbent beds. It is also helpful to heat trace the piping between the heater and the adsorber to prevent cooling and condensation.

6. The MERSORB ${ }^{*}$ mercury adsorbents have been shown to be effective at relatively high operating temperatures. Please contact your MERSORB* applications engineer for specific product recommendations for your particular situation. 


\section{NUCON International, Inc \\ 7000 Huntiey Rosd - Columbus, OH $492 \mathrm{~s}$ \\ Fh: 614848-5710 - Fx: 814491-0858 - www nuoon-Intoom}

\section{TECHNICAL SUPPORT}

NUCON technical personnel can provide:

A. Adsorption equilibrium data.

B. Dynamic adsorption data.

C. Process design engineering of the mercury removal process.

D. System fabrication and installation

E. On-site technical services.

D. Pilot scale adsorbers for slip stream tests.

MERSORB* applications engineers can advise users concerning potential recovery of mercury from spent adsorbent beds. 


\section{NUCON International, Inc}

7000 Huntiey Rosd - Columbuc, OH 49289

Ph: 614848-5710 - Fx: 614491-0858 - www.nuoon-Intoom

MERSORED

Meroury Adcorbente

Bullotin 11B28

Auguet 2004

\section{REFERENCES}

1. Lewis, Larry. "Measurement of Mercury in Natural Gas Streams." presented at the 74th Annual GPA Convention, San Antonio, Texas. March 1995.

2. Documentation of the Threshold Limit Values and Biological Exposure Indices, Sixth Edition, 1991, ACGIH, p 881.

3. Schroeder, Wrilam H. "Sampling and Analysis of Mercury and its Compounds in the Atmosphere," Environmental Science \& Technology, VoL. 16, No. 7, 1882. p 396A.

4. Ibid. $\mathrm{p} 304 \mathrm{~A}$.

5. Spencer, James N. and Voight, Adolf F., "Thermodynamics of the Solution of Mercury." Joumal of Physical Chemistry, Vol. 72, No. 2, Feb. 1968. p 466.

6. Masson, K. T. et al, "Mercury Removal from Liquid and Solid Mixed Waste Proceedings," WMQ5, Feb. 26 - March 2, 1995, Tuscon AZ

7 Tonini, D.R. et al "Achieving Low Mercury Concentrations in Chlor-Akali Wastewaters, Environmental Progress. Vol 22 No. 3, October 2003, p167-172

8 Poutsma, M.L., Ferris, L.M., Keller, OL., Mesmer, R.E., Chemistry Division Annuzal Progress Report. 1985, ORNL-615D. p 182-184.

9 Del Debbio, J.A., Watson, T.L., Heintzelman, J.B., Idaho National Engineering and Environmental Laboratory, Long-Term Perfomance of "Sulfur-Impregnated Granulated Activated Carbon (GAC) for Mercu ry Removal from NWCF Off-Gas, Status Report, INEEL/EXT-03-01102

10 Boardman, R.D.et al, Idaho National Engineering and Ervironmental Laboratory High Temperature MACT Calcination Test, Status Report, Feb 2002, INEEL/EXT-04-01625

11 Broderick, Thomas, ADA Technologies Inc., Spallation Neutron Source Carbon Adsorption Tests, Final Report, December 31,2002, SNS-108030700-TR0002-R00

12 Private Communication, Integrated Environmental Technologies, LLC, June 8, 2004 